\title{
The First-Class, the Familiar and the Forgettable: An analysis of Prime Ministerial performance in New Zealand
}

\author{
By \\ Katherine Anna-Clare Smith
}

\begin{abstract}
A thesis
Submitted to the Victoria University of Wellington

In fulfilment of the requirements for the degree of

Master of Arts in Political Science
\end{abstract}

School of History, Philosophy, Political Science \& International Relations

Victoria University of Wellington

2019 


\section{Table of Contents}

Acknowledgements $\quad 5$

$\begin{array}{ll}\text { Abstract } & 7\end{array}$

Tables and Figures $\quad 9$

Chapter One: Thesis Overview 11

Thesis Aims $\quad 12$

Thesis Structure 13

$\begin{array}{ll}\text { Chapter Two: Literature Review } & 17\end{array}$

Components of Political Leadership 17

Leadership Ranking Scholarship in New Zealand 22

Sheppard $1998 \quad 22$

Johansson and Levine 2011 27

Leadership Ranking Scholarship in the United States of America 31

Schlesinger Ranking Studies 1948, 1962, 1996

Other Ranking Studies 33

Leadership Ranking Scholarship in the rest of the world 37

United Kingdom 37

Canada 42

Australia 46

Chapter Three: Methodology 49

Chapter Four: Data and Analysis $\quad 55$

The initial responses $\quad 55$

Calculation of results $\quad 56$

The 2018 study: A replication of the Sheppard (1998) and Johansson and Levine (2011) methodology 57

An alternative survey: A replication of the Schlesinger (1948, 1962 and 1996)

methodology 60

A new survey: the analysis of generational shifts and recall rates 62

Pols 111: The entry-level student perspective $\quad 62$

Pols 353: The final year Bachelor's student perspective 64

Pols 428: The postgraduate perspective 67 
Replication of multi question methods

Contrast with 1998 and 2011 results $\quad 69$

$\begin{array}{ll}\text { The top three } & 75\end{array}$

The new entrants: Key and English $\quad 80$

The best Prime Minister New Zealand 'never had' 82

The Schlesinger Models $\quad 82$

Single question methods versus multi question methods 83

The wildcard: Robert Muldoon $\quad 88$

The generational shift: a new survey 90

The impact of the 'recency effect' 93

'The first class, the familiar and the forgettable': A new way of ranking 95

Chapter Six: Limitations and Future Studies $\quad 99$

$\begin{array}{ll}\text { Limitations } & 99\end{array}$

Cultural Limitations $\quad 99$

$\begin{array}{lr}\text { Data Limitations } & 101\end{array}$

Methodological Limitations 103

$\begin{array}{ll}\text { Future studies } & 105\end{array}$

$\begin{array}{ll}\text { Chapter Seven: Conclusion } & 107\end{array}$

$\begin{array}{ll}\text { Appendices } & 111\end{array}$

Appendix 1
Information Sheet for Participants (Survey 1)

Appendix 2
Survey 1: Replication of Sheppard (1998), and Johansson and Levine (2011)

Appendix 3

Information Sheet for Participants (Survey 2) 117

Appendix 4

Survey 2: Replication of Schlesinger methods $\quad 120$

Appendix 5

Survey 3: Testing generational shifts and recall rates 122

Appendix 6

List of initial sample $\quad 123$

Appendix 7

Email to participants $\quad 125$

Appendix 8

Email to Bessie Sutherland (Association of Former Members of Parliament) 126

Bibliography 


\section{Acknowledgements}

This work has not been accomplished without the help of significant people in my life, and it only feels fitting to pay my due respects towards them.

Firstly, gratitude and thanks must be paid to my supervisor, Professor Stephen Levine. Your guidance and supervision have been invaluable, and I am extremely grateful that unexpected circumstances led to you supervising this thesis. Not once would I leave one of our meetings without a new idea or approach towards this research, or at least an interesting story. I am glad that you will remember me as the student with the same name as the famous singer that sang 'God Bless America'. Thanks must also be paid to Dr. Jon Johansson and Dr. Chris Eichbaum. Without your help and guidance over the past 6 years, I am unsure if I would have succeeded as much as I have.

There are a lot of people in my life I wish to pay thanks to, but some stand out in particular. Gen, Aedan, Matthew, Brodie, Kaitlin and my flatmates: thanks for having faith in me when I didn't, and for being some of the best support I could have had over the last few years. You are some of the greatest friends one could ask for, and I am so proud of you all and excited to see what you do with your lives. To the entire team at The Warehouse Tory Street: thank you for being wonderful co-workers, and for being extremely considerate about my hectic university schedule. You have been a breath of fresh air every weekend amongst the chaos that is postgraduate study.

To everyone who has helped with any part of this thesis - whether it be teaching me how to use Microsoft Excel and format properly, proof-reading my rough drafts, or just offering to give me a hand at some stage - you have no idea how much I appreciate you. I'm sure this final piece wouldn't look as good as it does now without your help.

Lastly, this thesis is dedicated to my mother Lynley, my father Simon, and my sister Laura. When I graduated with my honours degree, I said that over the past few years you have seen me at my worst, but that you have also seen me at my best. I stand by this completely. Thank you for being the biggest support system I could have ever wished for, for pushing me to do more, and for putting up with a sometimes-insufferable daughter and sister. Everything I have done over the past 6 years has been for you. I hope I've made you proud. 


\section{Abstract}

Within the literature associated with political leadership, scholarship directly focused upon political performance in office is thinly conducted, both in New Zealand and in other areas across the world. This thesis aims to greater understand political leadership and performance in New Zealand, and address the gaps in the literature correlated with Prime Ministerial performance. To do this, this thesis provides a current list of rankings of former Premiers and Prime Ministers in New Zealand and identifies the dimensions that one must fulfil to display exceptional performance in office. To undertake this research, this thesis uses a series of surveys - distributed to students at Victoria University of Wellington, and to other individuals with a professional interest in politics and history in New Zealand - to best assess public perceptions towards political performance. Building upon the path dependency created by former exercises of the same nature in New Zealand (conducted by Simon Sheppard in 1998, and by Jon Johansson and Stephen Levine in 2011), this thesis provides a snapshot of the current public perceptions of outstanding political performance. In a similar nature to the earlier studies, this thesis identifies the dimensions of longevity, death in office, and being a 'big change' or crisis Prime Minister as being directly correlated with elevated performance in office. Additionally, this thesis investigates whether a series of variables - namely time between exercises in New Zealand, and the appearance of a possible recency effect- provide any influence or change over results. Additionally, this thesis moves outside the scope of exercises conducted previously in New Zealand, by ranking Prime Ministerial performance using a series of different methodologies. In conjunction with a replication of the exercises already conducted in New Zealand, this survey also assesses Prime Ministerial performance by using a survey based upon the well-cited Schlesinger ranking studies in the United States, and a third survey aimed to assess political shifts and levels of knowledge and recall rates amongst university students. Regardless of such factors, the results of this thesis remain consistent with previous exercises, with Michael Savage, Richard Seddon, Helen Clark and Peter Fraser being regarded by the political and academic elite across all surveys as embodying the highest qualities of successful political leadership in New Zealand. 


\section{Tables and Figures}

Table 2.1. Results of 1998 study by overall appraisal of performance 25

Table 2.2. Results of 1998 study by mean score of performance categories 26

Table 2.3. Results of 2011 study by overall appraisal of performance 28

Table 2.4. Results of 2011 study by mean score of performance categories 29

Table 2.5. Results of Presidential Ranking Studies in the United States 35

Table 2.6. Results of Prime Ministerial Ranking Studies in the United Kingdom 40

Table 2.7. Results of Prime Ministerial Ranking Studies in Canada 45

Table 2.8. Results of Prime Ministerial Ranking Studies in Australia 49

Table 3.1. Premiers/Prime Ministers with less than six months in office or who never fought an election $\quad 52$

Table 4.1. Results of 2018 survey by overall appraisal of performance 57

Table 4.2. Results of 2018 survey by mean score of performance categories 59

Table 4.3. Results of 2018 survey following the Schlesinger method 60

Table 4.4. Pols 111: Best and Worst Prime Ministers (March 2018) 63

Table 4.5. Pols 353: Best and Worst Prime Ministers (March 2018) 64

Table 4.6. Pols 353: Best and Worst Prime Ministers (June 2018) 66

Table 4.7. Pols 428: Best and Worst Prime Ministers (March 2018) 68

Table 5.1. Comparison of 1998, 2011 and 2018 results by overall appraisal of $\begin{array}{ll}\text { performance } & 70\end{array}$

Table 5.2. Comparison of 1998, 2011 and 2018 results by overall mean score of $\begin{array}{ll}\text { performance categories } & 73\end{array}$

Table 5.3. Comparison of Savage Rankings 1998/2011/2018 75

Table 5.4. Comparison of Clark Rankings 2011/2018 77

Table 5.5. Comparison of Seddon Rankings 1998/2011/2018 78

Table 5.6. Comparison of 2018 results with results following Schlesinger methodology 84

Table 5.7. Breakdown of student assessment by position of political party 93

Table 5.8. 'The First-Class, the Familiar, and the Forgettable' 95 


\section{Chapter One: Thesis Overview}

New Zealand is prominently recognized on a global scale for many things, whether it be our participation in sports, or our 'clean green' image that is frequently cited in other countries across the world. Historical figures are looked upon, with former rugby players, mountaineers and entertainers being some of our most recognized figureheads and names. Despite this, when analysing the historical figures that have helped to shape our nation as it is known today, much of the conducted research is limited to that of our sporting successes, and other prominent individuals are frequently overlooked. ${ }^{1}$ Those individuals that have contributed to the political successes of our small nation are often left out of the history books, with few New Zealanders knowing the history and achievements (or failures) of the Premiers and Prime Ministers that have held office.

Political leadership is becoming an ever-increasing field of research in academia. This forthcoming thesis will investigate a particular subsection of political leadership: the measurement of political leaders' performance. The measurement of political leaders' performance is a concept in political science literature that has been observed for decades, but literature directly correlated with the subject is limited, so it remains an under-researched area of political leadership. However, leader rankings research is persistent and growing internationally with studies being undertaken on a more frequent basis across the globe. To undertake such a study, therefore, helps provide further insights into political leadership and its performance that would not otherwise be known. It also adds richness towards history's milestones and memories. The narrative quality of individual political leaders as markers of epochs, generations, particular moments in history, and economic times is strong.

As stated, previous research has been thinly conducted internationally, with studies undertaken in nations such as (predominantly) in the United States, the United Kingdom, Australia, Canada, and Switzerland. Journalistic ranking proliferates more than these studies, which reinforces the importance of greater scholarly attention. In New Zealand, there has also been little research, which has only been conducted over the past 20 years. The last ranking study conducted in New Zealand was done in 2011, and published in 2013, by Jon Johansson

\footnotetext{
${ }^{1}$ As Simon Sheppard noted in his 1998 study, most analysis of historical figures in New Zealand is limited to that of the sports sphere, with a particular focus on former and current rugby and cricket players.

See Simon Sheppard. 1998. 'Ranking New Zealand's Prime Ministers.' Political Science, vol. 50. p. 72
} 
and Stephen Levine. Since this study we have seen two further completed prime ministerships, John Key and Bill English. Johansson and Levine replicated the initial survey conducted in 1998 by Simon Sheppard, which was the first of its kind within New Zealand. The studies showed significant stability and interest, with Jenny Shipley and Helen Clark new interesting additions to the discussion of political leadership in New Zealand. While any leadership scholar would always balance rankings survey research with other measures and concepts associated with the expression of leadership, they have their place. There are mostly biographical studies of New Zealand Prime Ministers so survey research can only enrich these studies. I endeavour to further the extant rankings research by conducting a series of surveys to gather data which can then be used to form a further and future study.

\section{Thesis Aims}

This thesis seeks to achieve a set of aims, as outlined below. Firstly, as previously mentioned, this thesis creates and executes a series of viable surveys ranking former New Zealand Premiers and Prime Ministers. These surveys build upon ranking exercises conducted in 1998 by Simon Sheppard, and again in 2011 by Jon Johansson and Stephen Levine. This thesis provides a current list of rankings of former office holders, complementing the existing exercises and providing further rich insight to political leadership and history in New Zealand.

Secondly, this thesis endeavours to build upon the scholarship in a sparse field of political leadership both in New Zealand and across the world. By doing so, this thesis promotes the expansion of this field of literature, further developing and exploring existing scholarship.

Following on from the 2011 study, this thesis continues to investigate the former research undertaken by Johansson and Levine that looks at how time plays a factor in producing different results. ${ }^{2}$ In order to achieve this aim, this thesis contrasts the surveys that are undertaken with those that were conducted in both 1998 and 2011, identifying whether different results have arisen due to changes over time. This thesis also explores the concept of

\footnotetext{
${ }^{2}$ See Jon Johansson and Stephen Levine. 2013. 'Evaluating Prime-Ministerial Performance: The New Zealand Experience.' In Paul Strangio, Paul 't Hart, \& James Walter (eds). Understanding Prime Ministerial Performance: Comparative Perspectives. Oxford: Oxford University Press. p. 300.
} 
a 'recency effect', identifying if such an effect also plays a part in determining performance rankings. ${ }^{3}$

Finally, this thesis seeks to investigate a range of other factors that may also have an impact on the performance rankings of former Prime Ministers. In particular, the notion of methodology is explored, with this thesis testing a claim made by Arthur Schlesinger Jr, which argues that a more complex survey will produce the same results as a simplified one. ${ }^{4}$ In order to do this, this thesis explores the use of how different methodologies may produce different results. This aim is investigated by conducting a series of surveys that each use a different form of methodology, based upon surveys that have been conducted in both New Zealand and in other areas of the world. Furthermore, this thesis also seeks to identify whether generational changes provide differences in results. This variable is investigated by controlling the samples of participants in the various surveys.

\section{Thesis Structure}

This thesis is organised over seven chapters, including this brief introductory chapter. The second chapter primarily serves as a literature review. The literature review is divided into four components, examining the existing research that has been conducted and developed within this field. The first component seeks to identify the existing research that has been conducted on political leadership. In this section, particular focus is paid towards scholarship that focuses on components of successful (or unsuccessful) political leadership, as further in this thesis such components are used to analyse data that is produced from the forthcoming surveys.

\footnotetext{
${ }^{3}$ The recency effect refers to a psychological idea that deviates from the serial-position effect. The recency effect supports the idea that when recalling a list of items that have been read by a participant, those items towards the end of the list are recalled first as they are the most recent in the participant's mind. The recency effect sits opposite the primary effect, which claims that the earliest items on a list are also easiest recalled, on the serial position effect scale. The concept was coined by Hermann Ebbinghaus, who tested both theories upon himself and proved his thesis correct. See Herman Ebbinghaus. 2013. 'Memory: A Contribution to Experimental Psychology.' Annals of Neurosciences, vol. 20 (4), and James Deese \& Roger A. Kaufman. 1957. 'Serial Effects in Recall of Unorganized and Sequentially Organized Verbal Material.' Journal of Experimental Psychology, vol. 54 (3). p. 180.

${ }^{4}$ Arthur Schlesinger Jr. claimed in his 1997 study that there were multiple studies conducted in the United States that gave near identical rankings to those that had been conducted by Arthur Schlesinger Sr. despite having more complex and intimidating ways of ranking as opposed to a simple single question. See A. M. Schlesinger. 1997. 'Rating the Presidents: Washington to Clinton.' Political Science Quarterly, 112 (2). p. 181182.
} 
The second, third and fourth components of the literature review identify the scholarship that is directly correlated with this research. These components look at scholarship that demonstrates ranking studies in a range of nations. As this thesis research investigates the possibility of methodology having an impact on results, these components report on the successes and constraints that different forms of methodology can provide for surveying, using relevant case studies as examples. Firstly, the limited scholarship that has occurred in New Zealand ranking former Prime Ministers is identified and discussed, in the form of the past two studies that have been carried out in New Zealand, first by Simon Sheppard in 1998, and then again by Jon Johansson and Stephen Levine in 2011. Secondly, this thesis analyses scholarship surrounding the rankings of former Presidents that has occurred in the United States of America. Due to the vast amount of research that has been conducted in the United States, and the extent to which this has been referenced and replicated in other parts of the world, this section serves as its own component of the literature review as opposed to being grouped together with all international research. Finally, relevant scholarship pertaining to ranking studies carried out in other parts of the world is also noted and briefly discussed.

The methodology of this research is crucial for providing significant survey results, and the third chapter provides analysis of the chosen methodology for this thesis. This chapter provides a comprehensive breakdown of the methodology that has been chosen for this thesis, identifying the three surveys that are being used to complete this research. This chapter helps the reader gain a greater understanding of how the research aims are being met and provides the guidelines for how surveys are being conducted. Brief information on the participants chosen to take part in this research is also provided, as well as an explanation as to why this thesis has taken a quantitative approach as opposed to a qualitative one.

The fourth chapter analyses the data from the surveys. In doing so, this chapter is divided into three subsections, each focusing on one of the different survey methods that have been used. This section looks at the ranking results from each different survey, contrasting them against one another to identify differences in rankings.

Chapter five focuses on the discussion of the results in regard to the aims of this thesis. This chapter critically examines the results of the three surveys. In particular, the results are analysed in contrast to the previous New Zealand studies undertaken. This chapter seeks to determine why the rankings have appeared as such, with discussion focused on select Prime 
Ministers that may have unprecedented rankings, as well as those with the highest or lowest rankings. This chapter further explores the backgrounds and history of said Prime Ministers to help to explain why they gained their particular rankings. This chapter critically analyses the different forms of methodology, one against the other, identifying whether significant differences in results occurred, and whether the methodology was a factor in any way responsible. The penultimate chapter of the thesis reviews the limitations that have been identified through the research, including those that may impact on the usefulness and validity of this thesis and its findings. The chapter concludes by exploring potential future studies that could be undertaken in this field of New Zealand political science.

With scholarship persisting and expanding in this subject area, it is important to explore the future that may lie ahead for this literature and its place in New Zealand leadership studies. Each chapter of this thesis contributes towards the exploration of performance rankings in New Zealand, helping to enrich our understanding of New Zealand's political history. 


\section{Chapter Two: Literature Review}

As one of the many categories representing leadership, political leadership stands as an elusive and often hard to define concept. Whilst under-researched, political leadership is a growing area of scholarship within the realm of political science. Despite this, scholarship on the subject varies, with many different defining factors on the concept being discussed. This chapter illustrates the literature that exists surrounding political leadership. In order to support this thesis, this chapter firstly observes the scholarship that concerns components of political leadership and explores scholarship that analyses the ways in which a leader is regarded as successful. Following this, scholarship involving the assessment of political leaders both in New Zealand and elsewhere is investigated.

\section{Components of Political Leadership}

The components of a successful political leader vary, with many scholars giving different accounts of what makes a leader successful. To define political leadership under the umbrella term of leadership proves difficult, as it is noted by scholars that the concept of leadership as a whole is as 'much confused as clarified by social theory' with leadership often being referred to as an 'omnibus term applied indiscriminately to varied roles' ${ }^{5}$ Therefore, it makes sense to define political leadership as its own concept, although this feat still proves difficult, with many different definitions appearing within political science scholarship. For the purpose of this thesis, the definition of political leadership given by Jon Johansson in his book Two Titans: Muldoon, Lange and Leadership will be considered.

'Political leadership is a dynamic interaction that occurs between an elected leadership (whether individual or group-based) and its citizenry. It is mediated to varying degrees by situational constraints and opportunities. A leader or leaders combining power and purpose to achieve certain shared objectives with the citizenry characterizes the leadership interaction. ${ }^{6}$

\footnotetext{
${ }^{5}$ It is noted that leadership is hard to define as an umbrella term due to the vast type of 'leaders' that are covered. For example, a playground leader in a schoolyard would fall under the same definition as a president of a country, despite the different contexts in which each leader takes part. See Léon Dion. 1968. 'The Concept of Political Leadership: An Analysis.' Canadian Journal of Political Science. 1 (1). p. 3.

${ }^{6}$ See Jon Johansson. 2005. Two Titans: Muldoon, Lange and Leadership. Wellington: Dunmore. p. 19.
} 
The idea of accessibility for political leadership prevails in New Zealand, which can be linked back to Johansson's definition, particularly in regard to the interaction between an elected leadership and its citizenry. ${ }^{7}$ If accessibility towards a political leader is not possible, then the interaction between the two entities will be compromised. Simon Power argues that being recognisable is the key ingredient for a political leader - a fundamental element of accessibility between a leader and the public. However, he further states that they should not be recognised as an individual, but rather as ordinary - a leader that fits in with the crowd. ${ }^{8}$ In particular, a leader that is accessible and reflects the values and lifestyles of average voters tends to fit more into populist beliefs than those leaders that are already extraordinary. ${ }^{9}$ The public tends to react better towards one person, as opposed to a group of leaders, hence why some former Prime Ministers have stood above the rest. Power uses the example of President John F. Kennedy to illustrate such a point: Kennedy's politics were tactile in the US as he represented a generational statement, and began to personify the issues that voters had been dealing with in previous years. ${ }^{10}$ As the first US president born in the twentieth century, he appealed to voters as the 'man they wished they could be, or the son parents never had. ${ }^{11} \mathrm{He}$ related to voters as someone extraordinary and charismatic, although he was still able to understand and represent the nation. Power argues that Kennedy knew how to make a political leadership role fun, and the optimism that he displayed allowed voters to relate to him more so than former Presidents. ${ }^{12}$

One thing that must be considered when analysing scholarship on political leadership is the context in which said leadership is observed. In his work 'Perceptions of Leadership', Keith Dowding brings up the important fact that the success of leadership is dependent on the context in which it is found, and that leadership is different everywhere. ${ }^{13} \mathrm{He}$ notes the importance of psychological factors detrimental to successful political leadership. ${ }^{14}$ In

\footnotetext{
${ }^{7}$ See Simon Power. 2004. 'The Ingredients of Successful Political Leadership.' Political Science. 56 (2). p. 11 and Raymond Miller. 2008. 'Taming Leadership? Adapting to Institutional Change in New Zealand Politics.' In Paul t’Hart and John Uhr (eds). Public Leadership: Perspectives and Practices. Canberra: ANU Press. p. 255.

${ }^{8}$ See Simon Power. 'The Ingredients of Successful Political Leadership.' p. 11.

${ }^{9}$ See Raymond Miller. 'Taming Leadership? Adapting to Institutional Change in New Zealand Politics.' p. 255.

${ }^{10}$ See Simon Power. 'The Ingredients of Successful Political Leadership.' p. 12.

${ }^{11}$ Ibid.

${ }^{12} \mathrm{Ibid}$

${ }^{13}$ See Keith Dowding. 2008. 'Perceptions of Leadership.' In Paul t'Hart and John Uhr (eds). Public Leadership: Perspectives and Practices. Canberra: ANU Press. p. 93.

${ }^{14}$ Dowding notes the importance of personal psychological characteristics; however, for the most part when referring to psychological factors he is noting the importance of factors dependent on the setting or context. See Keith Dowding. 'Perceptions of Leadership.' p. 93.
} 
particular, it should be considered that there tend to be different qualities that are dependent on the setting that define a political leader, and that leadership should not simply be limited to one particular set of psychological factors. To illustrate this, Dowding brings up the notion that some qualities that may be good in one nation may not be as effective in another. For example, Dowding notes the differences between the American and Australian political systems; where Australian Prime Ministers are expected to be able to handle the 'rough-and-tumble' of a daily parliamentary question time, the US president has no direct equivalent, and is almost protected from direct accountability. ${ }^{15}$

Dowding also illustrates the importance of large scale events that may influence the perception of political leadership. In particular, he notes how war leaders tend to be viewed as opposed to those who did not hold office during war. His analysis of Margaret Thatcher notes that during the Falklands War, Thatcher was consistently perceived as 'a leader with authority'. ${ }^{16}$ Such a judgement was mainly due to going against public opinion and sending troops to win back the Falkland Islands for the United Kingdom, and rightfully earned her the title of 'the Iron Lady.' ${ }^{17}$ Similar conclusions can be made when observing the leadership of Winston Churchill or Franklin D. Roosevelt - with public perceptions of leadership often being higher, which could be an attribute of being a war-time Prime Minister or President. Serving during war offers a higher perception of enhanced leadership, giving some leaders an advantage over those who did not.

Perceptions of the public can also be considered detrimental to a leader's success and can just as easily cause a leader to fall as it may have caused them to rise. Dowding notes the reason for this as being that leaders can begin to believe the perceptions of themselves that are presented to them, despite the fact that many of them may be false. ${ }^{18}$ This can often cause leaders to forget the important factors that may have caused them to be perceived as strong. ${ }^{19}$

When observing components of political leadership from a New Zealand perspective, significant scholarship has arisen. As the realm of political leadership begins to be explored more frequently within scholarship, characteristics have begun to arise that are used to define

\footnotetext{
${ }^{15}$ See Keith Dowding. 'Perceptions of Leadership.' p. 93.

${ }^{16}$ Ibid.

${ }^{17}$ Ibid.

${ }^{18}$ Ibid., p. 100.

${ }^{19}$ Ibid.
} 
the successful leadership of a New Zealand Prime Minister. Michael Bassett explores the characteristics believed to be essential in twentieth century New Zealand politics, and identifies the fundamentals vital to succeeding in the top spot as Prime Minister. Bassett notes the changes to New Zealand politics that have occurred over the last century, namely the fact that politics has moved from being a retirement job to a career. ${ }^{20}$ Bassett notes that the field of politics has become a game for younger players and 'as the sport got more onerous, older players were retired or frightened off.' ${ }^{21}$ Sixty years ago, politicians would rise to the top of their field before entering politics as a stepping stone to retirement, whereas nowadays it is almost mandatory that a career in politics is started at an earlier age should a politician wish to have success. Such a shift was detrimental to the changing pace of parliamentary life - the workload was increased, and parliament sat for longer at a time. ${ }^{22}$ Furthermore, the public expectations of parliamentarians were changed, where constituents were expecting far more from their elected officials than they once were, no matter the time of year or what happened to be on the parliamentary agenda at the time. ${ }^{23}$ A need for younger people stepping up into political careers has become vital in ensuring success, due to constant movement being tiring for those of the older generations and the job requiring high amounts of energy. ${ }^{24}$

With the changing context of the parliamentary setting in New Zealand over the past century, politicians have also had to adapt to the introduction of television - a form of media that allows every aspect of a politician's body language to be scrutinised by their constituents. ${ }^{25}$ Bassett illustrates his point by mentioning Richard Seddon - a Prime Minister who would have met the rest of the characteristics associated with success, although television would have failed him. Seddon would have been too big for the screen, and Bassett argues that his overbearing personality and stentorian voice would have been captured on screen and might have turned people against him. ${ }^{26}$ In contrast, it is also noted how television has also managed to work for some politicians - Muldoon's small stature was disguised by the cameras, and combined with

\footnotetext{
${ }^{20}$ See Michael Bassett. 1999. 'The Essentials of Successful Leadership in Twentieth-Century New Zealand Politics.' Political Science. 51 (2). p. 108.

${ }^{21}$ Ibid.

${ }^{22}$ Ibid., p. 109.

${ }^{23}$ Bassett notes the increase in parliamentarian appearances over the last sixty years, with it becoming an expectation that they would attend events in their electorates, whether they be minor or major. It has since become common that MPs make trips out of Wellington on a weekly basis, sometimes more than once, whereas in the earlier days of New Zealand politics such a factor was uncommon. See Michael Bassett. 'The Essentials of Successful Leadership in Twentieth-Century New Zealand Politics.' p. 109-110.

${ }^{24}$ Ibid., p. 110.

${ }^{25}$ Ibid.

${ }^{26}$ Ibid., p. 111.
} 
his constant unpredictability on television, it allowed him to draw in viewers, despite their opinions of him. ${ }^{27}$ Muldoon became a television force during his time in politics, contributing towards his success as a politician and Prime Minister.

Bassett also notes a range of characteristics believed to be fundamental to the success of a politician. Despite the changing pace of parliament over the past century, Bassett argues that the need for 'robust health, high energy levels, a good temperament, intelligence, a willingness to take the right and a modicum of luck' have been constants throughout successful political leadership in New Zealand. ${ }^{28}$ Other scholarship that notes important personal qualities looked for within a New Zealand Prime Minister include the components of 'strong and decisive action, empathy, and an ability to reflect the country's egalitarian traditions and contribute towards a growing sense of nationhood.' ${ }^{29}$ Charisma, a supportive spouse and superior vison and decision-making abilities have also contributed to a political leader's success. ${ }^{30}$ These components have allowed some leaders to be considered successful in domestic and international politics and play a large role in elevating public perceptions of a politician's performance in office.

\footnotetext{
${ }^{27}$ See Michael Bassett. 'The Essentials of Successful Leadership in Twentieth-Century New Zealand Politics.' p. 111.

${ }^{28}$ Ibid., p. 108.

${ }^{29}$ See Raymond Miller. 'Taming Leadership? Adapting to Institutional Change in New Zealand Politics.' p. 255.

${ }^{30}$ See Michael Bassett. 'The Essentials of Successful Leadership in Twentieth-Century New Zealand Politics.' p. 108.
} 


\section{Leadership ranking scholarship in New Zealand}

Political leadership scholarship in New Zealand has been mainly limited to the biographical perspectives of former Prime Ministers. Whilst these biographies provide a rich inside perspective of the circumstances that a former Prime Minister may have worked under, it gives an individual approach as opposed to an overall look at political leadership in New Zealand. However, in recent years academic scholarship has begun to develop, and there has been a rise in the literature examining political leadership in New Zealand. Many scholars are adopting frameworks from overseas scholarship to apply to a New Zealand context, and are looking more towards concepts of political leadership as opposed to an individual leader. In conjunction, scholars are also beginning to look at leaders collectively in the New Zealand setting, with literature studying all Prime Ministers together becoming more prevalent. ${ }^{31}$

As the realm of scholarship observing political leadership in the New Zealand context begins to gain traction, literature has taken a further turn towards the comparative assessment of political leaders. For the most part, this scholarship has involved assessing the success of former Prime Ministers, although the success of deputy Prime Ministers has also been evaluated from a comparative perspective. ${ }^{32}$

\section{Sheppard 1998}

In 1998, a young scholar by the name of Simon Sheppard produced the first ever study providing a comparative assessment of former New Zealand Prime Ministers. Such scholarship had never been seen in a New Zealand context before, and Sheppard was influenced by similarly designed studies that had been conducted in the United States. Eager to produce a similar study applied to the New Zealand context, Sheppard created a survey designed to bring forth the perspectives of relevant participants; namely scholars and former Members of

\footnotetext{
${ }^{31}$ Scholarship worth noting includes Ian Grant. 2003. Public Lives: New Zealand's Premiers and Prime Ministers 1856-2003. Wellington: New Zealand Cartoon Archive and Michael Bassett. 2017. New Zealand's Prime Ministers: From Dick Seddon to John Key. Mangawhai: David Ling. Ian Grant's work observes all Prime Ministers from 1856 through until the time of publication in 2003, whereas Michael Bassett analyses the performance of Prime Ministers starting with Richard Seddon in 1893, through until 2017.

32 In 2009, the work of Simon Sheppard inspired a Victoria University graduate student, Steven Barnes, to undertake a similar comparative assessment exercise. Albeit modified, Barnes used Sheppard's methodology seen in his 1997 survey to complete an assessment of the performance and success of former deputy Prime Ministers in New Zealand. See Steven Barnes. 2009. 'What About Me? Deputy Prime Ministership in New Zealand.' Political Science, 61. (1), 33-49.
} 
Parliament. Sheppard took inspiration from two surveys that had been prominent in the comparative assessment of former US Presidents and created a methodology appropriate for assessing the performance of former New Zealand Prime Ministers. Firstly, Sheppard took inspiration from a survey that had been conducted by the Chicago Tribune in 1982, in which participants were asked to rate all former Presidents on a five-fold scale of categories. ${ }^{33}$ Some modification occurred in order to make the question relevant to the New Zealand political system, and the first part of the survey was formed. ${ }^{34}$ Following this, Sheppard took inspiration from the surveys that had been conducted by historian Arthur Schlesinger in order to form his second question, which was unique in itself but extremely complementary to the first section of the questionnaire, allowing respondents to make an accurate comparative assessment of former New Zealand Prime Ministers. The Schlesinger surveys were well cited in the United States and in other parts of the world and had resulted in plausible results being produced each time they were conducted.

Assessing 30 of New Zealand's former Prime Ministers, respondents were asked to complete the survey in two sections, with one inspired by the two aforementioned studies conducted in the United States. Firstly, respondents were asked to give a ranking on a scale of one to ten for each Prime Minister in each category, with one being the lowest score and ten being the highest. The categories, and their explanations, were given to each participant as follows.

- Leadership Qualities: the degree to which the prime minister could motivate and inspire the nation at large, swing the people behind a legislative agenda, and win an election.

- Parliamentary Skills: how effective the prime minister was in maintaining a parliamentary majority; the extent to which they could dominate the opposition in parliament, set the agenda in debate and question time, and manipulate the media.

\footnotetext{
${ }^{33}$ The categories were as follows: leadership qualities, accomplishments and crisis management, political skills, quality of appointments, and character and integrity. See Kenneth Janda, Jeffrey M. Berry, and Jerry Goldman, (eds). 1992. The Challenge of Democracy: Government in America ( $3^{\text {rd }}$ Ed.). Boston: Houghton Mifflin. p. 443. ${ }^{34}$ Sheppard replaced the categories of quality of appointments, and character and integrity, for others appropriate to the New Zealand setting. Furthermore, he slightly modified the categories of political skills and accomplishments and crisis management to better fit the survey. See Simon Sheppard. 'Ranking New Zealand's Prime Ministers.' p. 75-76.
} 
- Party Management: how effective the prime minister was in maintaining unity and purpose in their caucus and cabinet; how well they dealt with dissent; their relationship with the party at large (if any).

- Crisis Management: how effectively the prime minister responded to unexpected developments (economic, political, military, natural disasters, etc.).

- Legislative Achievements: the legacy for which the prime minister is responsible; the extent to which their term in office was the catalyst for positive change in New Zealand politics, economy and society. ${ }^{35}$

Secondly, the survey asked respondents to give an overall appraisal of each Prime Minister on an A-E scale (with A being outstanding and $\mathrm{E}$ being failure), taking inspiration from the Schlesinger surveys. Following the two main questions of the survey, the Sheppard study also included an optional component that allowed respondents to note who they believed to be the best Prime Minister New Zealand never had. A total of 75 questionnaires were distributed to a range of participants, namely historians, political scientists, journalists and current and former Members of Parliament. ${ }^{36}$ Some questionnaires were also sent to sector group leaders and public servants. ${ }^{37}$ Participants were given the option to refrain from making a judgement with respect to any Prime Ministers with whom they were not familiar. Furthermore, the Prime Ministers included in the survey were limited, with questionnaires excluding those Prime Ministers who had never fought an election or had served less than six months in office. ${ }^{38}$ With the survey being designed to measure the performance of former office holders, the incumbent Prime Minster at the time of the exercise, Jenny Shipley, was also excluded.

\footnotetext{
${ }^{35}$ See Simon Sheppard. 'Ranking New Zealand's Prime Ministers.' p. 75.

${ }^{36}$ Ibid., p. 76.

${ }^{37}$ Those sector group leaders and public servants that received questionnaires were those that had 'worked closely with and were familiar with the New Zealand political environment and the role and history of the Prime Minister'. See Simon Sheppard. 'Ranking New Zealand's Prime Ministers.' p. 76.

${ }^{38}$ The following Prime Ministers were excluded from the 1997 exercise: Henry Sewell, George Waterhouse, William Hall-Jones, Thomas Mackenzie and Sir Francis Dillon Bell. Despite serving less than six months in office, Mike Moore was included in the survey due to fighting an election. Furthermore, William Fox was also included in the exercise, due to serving more than six months in his second term as Prime Minister. See Simon Sheppard. 'Ranking New Zealand's Prime Ministers. p. 77.
} 
Table 2.1. Results of 1998 study by overall appraisal of performance

\begin{tabular}{|c|c|c|c|c|c|c|c|c|c|}
\hline Rank & Prime Minister & A & $\mathrm{B}$ & $\mathrm{C}$ & $\mathrm{D}$ & $\mathrm{E}$ & Total score & $\begin{array}{l}\text { No. of } \\
\text { rankings }\end{array}$ & Mean \\
\hline 1 & Seddon, Richard & 85 & 12 & & & & 97 & 20 & 4.85 \\
\hline 2 & Fraser, Peter & 75 & 28 & 9 & & & 112 & 25 & 4.48 \\
\hline 3 & Kirk, Norman & 45 & 56 & 9 & 2 & & 112 & 27 & 4.15 \\
\hline 4 & Savage, Michael & 20 & 72 & 3 & & & 95 & 23 & 4.13 \\
\hline 5 & Ballance, John & 10 & 48 & 3 & & & 61 & 15 & 4.07 \\
\hline 6 & Holyoake, Keith & 25 & 68 & 9 & 2 & & 104 & 26 & 4.00 \\
\hline 7 & Vogel, Julius & 5 & 36 & 9 & 2 & & 52 & 14 & 3.71 \\
\hline 8 & Massey, William & 15 & 32 & 21 & 2 & & 70 & 19 & 3.68 \\
\hline 9 & Muldoon, Robert & 20 & 60 & 15 & 2 & 2 & 99 & 27 & 3.67 \\
\hline 10 & Stafford, Edward & 5 & 20 & 3 & & 1 & 29 & 8 & 3.63 \\
\hline 11 & Atkinson, Harry & & 20 & 12 & & & 32 & 9 & 3.56 \\
\hline 12 & Bolger, Jim & & 68 & 27 & 4 & & 99 & 28 & 3.54 \\
\hline 13 & Lange, David & 15 & 56 & 15 & 10 & 1 & 97 & 28 & 3.46 \\
\hline \multirow[t]{2}{*}{$14=$} & Nash, Walter & 5 & 40 & 30 & 8 & & 83 & 25 & 3.32 \\
\hline & Coates, Gordon & & 44 & 9 & 10 & & 63 & 19 & 3.32 \\
\hline 16 & Holland, Sidney & & 36 & 36 & 8 & & 80 & 25 & 3.20 \\
\hline 17 & Ward, Joseph & & 24 & 24 & 10 & & 58 & 19 & 3.05 \\
\hline 18 & Hall, John & & 8 & 3 & 6 & & 17 & 6 & 2.83 \\
\hline 19 & Rowling, Wallace & & 24 & 30 & 18 & 1 & 73 & 26 & 2.81 \\
\hline 20 & Stout, Robert & & 4 & 12 & 10 & & 26 & 10 & 2.60 \\
\hline 21 & Grey, George & & 2 & 24 & 6 & 1 & 33 & 13 & 2.54 \\
\hline 22 & Palmer, Geoffrey & & 16 & 24 & 28 & 2 & 70 & 28 & 2.50 \\
\hline 23 & Marshall, John & & 12 & 24 & 24 & 2 & 62 & 25 & 2.48 \\
\hline 24 & Moore, Mike & & 16 & 24 & 18 & 5 & 63 & 26 & 2.42 \\
\hline 25 & Weld, Fred erick & & 4 & 6 & & 2 & 12 & 5 & 2.40 \\
\hline 26 & Whitaker, Frederick & & 4 & & 6 & 1 & 11 & 5 & 2.20 \\
\hline 27 & Fox, William & & 4 & 3 & 4 & 2 & 13 & 6 & 2.17 \\
\hline \multirow[t]{2}{*}{$28=$} & Pollen, Daniel & & & 3 & 4 & 1 & 8 & 4 & 2.00 \\
\hline & Domett, Alfred & & & 6 & & 2 & 8 & 4 & 2.00 \\
\hline \multirow[t]{2}{*}{30} & Forbes, George & & & 9 & 16 & 7 & 32 & 18 & 1.78 \\
\hline & Average & & & & & & & & 3.15 \\
\hline
\end{tabular}

The results of the survey saw Richard Seddon take out the top position in each component of the exercise. Seddon was the only Prime Minister in the exercise to receive a mean score over 40 points and was therefore regarded by Sheppard as the 'choice by consensus of the surveys as New Zealand's greatest Prime Minister. ${ }^{39}$ Seddon was succeeded by Peter Fraser and Michael J. Savage in second and third place respectively, with John Ballance and Sir Keith Holyoake entering in the fourth and fifth place positions to round out who respondents believed to be the top five Prime Ministers (in terms of the five performance categories). Seddon also received the first-place ranking by respondents in regard to overall appraisal, with Fraser once again following behind in second place. Norman

\footnotetext{
${ }^{39}$ See Simon Sheppard. 'Ranking New Zealand's Prime Ministers.' p. 78.
} 
Kirk entered in third place for this component of the survey, compared to his sixth-place ranking in performance categories. ${ }^{40}$

Table 2.2. Results of 1998 study by mean score of performance categories

\begin{tabular}{|c|c|c|c|c|c|c|c|}
\hline Rank & Prime Minister & $\begin{array}{c}\text { Mean } \\
\text { leadership } \\
\text { qualities }\end{array}$ & $\begin{array}{c}\text { Mean } \\
\text { parliamentary } \\
\text { skills }\end{array}$ & $\begin{array}{c}\text { Mean party } \\
\text { management }\end{array}$ & $\begin{array}{l}\text { Mean crisis } \\
\text { management }\end{array}$ & $\begin{array}{c}\text { Mean } \\
\text { legislative } \\
\text { achievement }\end{array}$ & Mean \\
\hline 1 & Seddon, Richard & 9.05 & 8.38 & 8.24 & 7.71 & 8.33 & 41.71 \\
\hline 2 & Fraser, Peter & 7.50 & 7.85 & 7.65 & 7.96 & 7.65 & 38.61 \\
\hline 3 & Savage, Michael & 8.33 & 6.92 & 6.88 & 6.33 & 8.17 & 36.63 \\
\hline 4 & Ballance, John & 7.13 & 7.00 & 7.13 & 6.80 & 7.80 & 35.86 \\
\hline 5 & Holyoake, Keith & 7.19 & 7.74 & 7.89 & 6.85 & 5.67 & 35.34 \\
\hline 6 & Kirk, Norman & 8.11 & 7.64 & 6.93 & 6.46 & 5.93 & 35.07 \\
\hline 7 & Massey, William & 7.26 & 7.05 & 6.95 & 6.95 & 5.63 & 33.84 \\
\hline 8 & Vogel, Julius & 7.07 & 6.69 & 6.10 & 6.34 & 7.08 & 33.28 \\
\hline 9 & Muldoon, Robert & 7.39 & 8.21 & 6.82 & 6.00 & 4.46 & 32.88 \\
\hline 10 & Stafford, Edward & 6.86 & 6.57 & 6.25 & 6.00 & 5.80 & 31.48 \\
\hline 11 & Lange, David & 7.45 & 7.69 & 4.03 & 5.86 & 6.03 & 31.06 \\
\hline 12 & Holland, Sidney & 6.04 & 6.20 & 6.83 & 6.25 & 5.16 & 30.48 \\
\hline 13 & Atkinson, Harry & 6.20 & 6.50 & 5.56 & 6.11 & 6.00 & 30.37 \\
\hline 14 & Ward, Joseph & 6.21 & 7.21 & 5.84 & 5.68 & 5.37 & 30.31 \\
\hline 15 & Bolger, Jim & 5.93 & 6.38 & 6.14 & 6.31 & 5.17 & 29.93 \\
\hline 16 & Nash, Walter & 5.85 & 6.69 & 6.04 & 5.57 & 5.77 & 29.92 \\
\hline 17 & Coates, Gordon & 6.40 & 6.25 & 5.30 & 4.95 & 4.85 & 27.75 \\
\hline 18 & Grey, George & 6.75 & 6.17 & 4.10 & 5.09 & 5.00 & 27.11 \\
\hline 19 & Stout, Robert & 5.40 & 6.40 & 4.90 & 5.20 & 4.90 & 26.80 \\
\hline 20 & Rowling, Wallace & 4.44 & 5.44 & 5.48 & 5.00 & 4.44 & 24.80 \\
\hline 21 & Marshall, John & 4.15 & 5.92 & 5.00 & 4.85 & 4.16 & 24.08 \\
\hline 22 & Pollen, Daniel & 3.67 & 6.33 & 3.50 & 6.00 & 4.50 & 24.00 \\
\hline 23 & Palmer, Geoffrey & 3.69 & 5.76 & 4.52 & 4.41 & 5.45 & 23.83 \\
\hline 24 & Whitaker, Frederick & 4.17 & 6.67 & 4.25 & 5.00 & 3.60 & 23.69 \\
\hline 25 & Hall, John & 4.29 & 5.14 & 4.50 & 4.75 & 4.40 & 23.08 \\
\hline 26 & Fox, William & 6.00 & 6.67 & 4.00 & 3.34 & 3.00 & 23.01 \\
\hline 27 & Weld, Frederick & 5.40 & 4.80 & 3.67 & 4.25 & 3.50 & 21.62 \\
\hline 28 & Moore, Mike & 4.89 & 5.27 & 4.07 & 4.15 & 2.27 & 20.65 \\
\hline 29 & Forbes, George & 3.74 & 4.32 & 4.48 & 3.11 & 2.74 & 18.39 \\
\hline 30 & Domett, Alfred & 3.33 & 4.33 & 3.00 & 3.00 & 2.33 & 15.99 \\
\hline
\end{tabular}

The bottom placings of Prime Ministers also remained relatively similar across the two components, with George Forbes and Alfred Domett taking out the bottom two places in each section. Mike Moore entered rankings with very low placings, gaining $24^{\text {th }}$ place in terms of overall appraisal and $28^{\text {th }}$ place in the performance categories component. ${ }^{41}$ Overall, the nineteenth century premiers tended to be neglected by respondents, often resulting in lower

\footnotetext{
${ }^{40}$ For further information on the rankings of the Sheppard exercise, please refer to Table 2.1 (results by overall performance) and Table 2.2 (results by mean score of performance categories).

${ }^{41}$ It was noted in the study, and in the subsequent one that followed in 2011, that it may have been unfair to have included Mike Moore in the rankings, as his time in office of only 53 days was mainly spent campaigning, and respondents may not have been able to make the fairest of judgements due to his lack of time in office. See Jon Johansson and Stephen Levine. 'Evaluating Prime Ministerial Performance: The New Zealand Experience.' p. 301.
} 
rankings for these office holders. Such a trend was attributed to the lack of knowledge participants may have had for the earlier Premiers and Prime Ministers, as those serving later tended to receive more numerous and comprehensive rankings. ${ }^{42}$

\section{Johansson and Levine 2011}

Thirteen years later in 2011, the Sheppard rankings were bought to light again by Jon Johansson and Stephen Levine. Seeking to further expand on Sheppard's research and to measure movements in perceptions over time, Johansson and Levine replicated the initial framework and methodology used in the 1998 exercise, with participants being asked to rank former Prime Ministers over two different components - an overall appraisal of performance and in five different performance categories. Once again, participants were given the option to provide comments on who they believed to be the best Prime Minister New Zealand never had. ${ }^{43}$ The 2011 exercise saw the inclusion of Jenny Shipley and Helen Clark, each of whom had completed their time in office by the time of the study. The incumbent Prime Minister at the time, John Key, was excluded from the study.

The authors anticipated encountering the issue of New Zealand having a shortage of individuals who were knowledgeable about the country's earlier Premiers and Prime Ministers, in particular those who had served in the nineteenth and early twentieth century. In order to overcome this, the 2011 exercise had a far larger sample than Sheppard's initial 75 participants, in the hopes of receiving a larger number of completed questionnaires. ${ }^{44}$

The survey was sent to 265 participants. ${ }^{45}$ Of the questionnaires that were distributed, the 2011 exercise saw the return of 42 completed and usable responses, compared to the 30 received in

\footnotetext{
${ }^{42}$ See Simon Sheppard. 'Ranking New Zealand's Prime Ministers.' p. 89.

${ }^{43}$ The authors also sought to create a new path dependency in which a new generation of scholars may seek to compare Prime Ministerial performance in New Zealand with similar methods and data every 10-15 years. See Jon Johansson and Stephen Levine. 'Evaluating Prime Ministerial Performance: The New Zealand Experience.' p. 300 .

${ }^{44}$ Ibid.

${ }^{45}$ Participants again consisted of historians, political scientists, journalists, members of the Association of Former Members of Parliament, and others who had either worked for or showed interest in New Zealand Prime Ministers. See Jon Johansson and Stephen Levine. 'Evaluating Prime Ministerial Performance: The New Zealand Experience. p. 300.
} 
the 1998 study. ${ }^{46}$ The 2011 exercise also saw a marginal improvement in the number of responses given for the nineteenth century premiers, with the average number of responses up to 13 , in contrast to the initial eight that were received by Sheppard in the original study. ${ }^{47}$

Table 2.3. Results of 2011 study by overall appraisal of performance

\begin{tabular}{|c|c|c|c|c|c|c|c|c|c|}
\hline Rank & Prime Minister & A & B & $\mathrm{C}$ & $\mathrm{D}$ & $\mathrm{E}$ & Total score & $\begin{array}{c}\text { No. of } \\
\text { rankings }\end{array}$ & Mean \\
\hline 1 & Fraser, Peter & 125 & 16 & 6 & & & 147 & 31 & 4.74 \\
\hline 2 & Seddon, Richard & 80 & 24 & 3 & & & 107 & 23 & 4.65 \\
\hline 3 & Savage, Michael & 80 & 44.25 & 12 & & & 136.25 & 31 & 4.40 \\
\hline 4 & Clark, Helen & 109.5 & 60 & 12 & 2 & & 183.5 & 42 & 4.37 \\
\hline 5 & Holyoake, Keith & 60 & 92.25 & 9 & & & 161.25 & 38 & 4.24 \\
\hline 6 & Kirk, Norman & 55 & 67.75 & 27.25 & 2 & 1 & 153 & 38 & 4.03 \\
\hline 7 & Ballance, John & 20 & 40 & 12.25 & & & 72.25 & 18 & 4.01 \\
\hline 8 & Massey, William & 20 & 44.25 & 9 & 2 & & 75.25 & 20 & 3.76 \\
\hline 9 & Vogel, Julius & 10 & 24 & 18 & & & 52 & 14 & 3.71 \\
\hline 10 & Bolger, Jim & 14.75 & 92.25 & 45 & 2 & & 154 & 43 & 3.58 \\
\hline 11 & Holland, Sidney & 5 & 60.25 & 36 & 2 & & 103.25 & 29 & 3.56 \\
\hline 12 & Coates, Gordon & 5 & 52.25 & 18 & & 2 & 77.25 & 22 & 3.51 \\
\hline 13 & Stafford, Edward & 10 & 12 & 9 & 4 & & 35 & 10 & 3.50 \\
\hline 14 & Lange, David & 10 & 76.25 & 45.25 & 8 & & 139.5 & 40 & 3.49 \\
\hline 15 & Palmer, Geoffrey & 5 & 36 & 75 & 20.25 & 6 & 142.25 & 42 & 3.39 \\
\hline \multirow[t]{2}{*}{$16=$} & Hall, John & 5 & 8 & 18 & 4 & 2 & 37 & 11 & 3.36 \\
\hline & Muldoon, Robert & 14.75 & 80.25 & 33.25 & 4 & 2 & 134.25 & 40 & 3.36 \\
\hline \multirow[t]{2}{*}{$18=$} & Ward, Joseph & & 36 & 18.25 & 6 & & 60.25 & 18 & 3.35 \\
\hline & Nash, Walter & 10 & 44 & 56.75 & 2 & 1 & 113.75 & 34 & 3.35 \\
\hline 20 & Stout, Robert & & 20 & 15 & 4 & & 39 & 12 & 3.25 \\
\hline 21 & Atkinson, Harry & 5 & 4 & 24 & 2 & & 35 & 11 & 3.18 \\
\hline 22 & Marshall, John & & 32 & 54.25 & 16 & & 102.25 & 34 & 3.01 \\
\hline 23 & Rowling, Wallace & & 40 & 51.25 & 20 & 1 & 112.25 & 38 & 2.95 \\
\hline 24 & Weld, Fred erick & & 12 & 12.25 & 4 & 1 & 29.25 & 10 & 2.93 \\
\hline 25 & Grey, George & 5 & 12 & 9 & 10 & 2 & 38 & 14 & 2.71 \\
\hline 26 & Shipley, Jenny & & 16 & 63 & 28 & 2 & 109 & 41 & 2.66 \\
\hline 27 & Moore, Mike & 10 & 20 & 30 & 38 & 3 & 101 & 39 & 2.59 \\
\hline 28 & Fox, William & & 12 & 9 & 8 & 2 & 31 & 12 & 2.58 \\
\hline 29 & Whitaker, Frederick & & 4 & 6 & 10 & 2 & 22 & 10 & 2.20 \\
\hline 30 & Pollen, Daniel & & & 9 & 6 & 2 & 17 & 8 & 2.13 \\
\hline 31 & Domett, Alfred & & 8 & & 6 & 5 & 19 & 10 & 1.90 \\
\hline \multirow[t]{2}{*}{32} & Forbes, George & & & 9 & 8 & 10 & 27 & 17 & 1.59 \\
\hline & Average & & & & & & & & 3.31 \\
\hline
\end{tabular}

\footnotetext{
${ }^{46}$ Of these responses, a further three were also received by the authors, bringing the total count of responses to forty-five. However, these three responses were discarded as unusable, and were not included in any final results that were produced. See Jon Johansson and Stephen Levine. 'Evaluating Prime Ministerial Performance: The New Zealand Experience.' p. 301.

${ }^{47}$ Ibid.
} 
Table 2.4. Results of 2011 study by mean score of performance categories

\begin{tabular}{|c|c|c|c|c|c|c|c|}
\hline Rank & Prime Minister & $\begin{array}{c}\text { Mean } \\
\text { leadership } \\
\text { qualities }\end{array}$ & $\begin{array}{c}\text { Mean } \\
\text { parliamentary } \\
\text { skills }\end{array}$ & $\begin{array}{l}\text { Mean party } \\
\text { management }\end{array}$ & $\begin{array}{l}\text { Mean crisis } \\
\text { management }\end{array}$ & $\begin{array}{c}\text { Mean } \\
\text { legislative } \\
\text { achievement }\end{array}$ & Mean \\
\hline 1 & Seddon, Richard & 8.50 & 8.33 & 8.22 & 7.71 & 8.61 & 41.37 \\
\hline 2 & Fraser, Peter & 8.22 & 7.73 & 8.00 & 8.41 & 8.33 & 40.69 \\
\hline 3 & Savage, Michael & 7.95 & 7.34 & 7.53 & 7.22 & 8.44 & 38.48 \\
\hline 4 & Clark, Helen & 7.60 & 7.56 & 8.17 & 7.24 & 6.87 & 37.44 \\
\hline 5 & Bolger, Jim & 6.68 & 7.72 & 7.89 & 7.51 & 7.18 & 36.98 \\
\hline 6 & Holyoake, Keith & 7.53 & 7.66 & 8.00 & 7.14 & 6.62 & 36.95 \\
\hline 7 & Kirk, Norman & 8.00 & 7.79 & 7.36 & 6.97 & 6.47 & 36.59 \\
\hline 8 & Ballance, John & 7.26 & 6.82 & 7.22 & 6.88 & 7.37 & 35.55 \\
\hline 9 & Massey, William & 7.32 & 7.59 & 7.24 & 7.13 & 6.26 & 35.54 \\
\hline 10 & Vogel, Julius & 7.14 & 6.64 & 6.38 & 7.00 & 7.86 & 35.02 \\
\hline 11 & Muldoon, Robert & 7.18 & 8.19 & 7.45 & 6.25 & 5.92 & 34.99 \\
\hline 12 & Holland, Sidn ey & 6.91 & 6.98 & 7.48 & 6.46 & 5.64 & 33.47 \\
\hline 13 & Lange, David & 6.91 & 7.64 & 5.00 & 5.62 & 6.51 & 31.68 \\
\hline 14 & Nash, Walter & 6.31 & 6.62 & 6.34 & 6.12 & 6.12 & 31.51 \\
\hline 15 & Stafford, Edward & 6.50 & 6.67 & 5.75 & 6.38 & 5.89 & 31.19 \\
\hline 16 & Coates, Gordon & 6.68 & 6.11 & 5.86 & 5.95 & 5.25 & 29.85 \\
\hline 17 & Ward, Joseph & 6.33 & 6.38 & 5.74 & 5.47 & 5.68 & 29.60 \\
\hline 18 & Rowling, Wallace & 5.54 & 5.65 & 6.05 & 5.59 & 5.44 & 28.27 \\
\hline 19 & Marshall, John & 5.46 & 6.15 & 5.64 & 5.55 & 5.44 & 28.24 \\
\hline 20 & Grey, George & 7.00 & 5.75 & 4.73 & 5.50 & 4.69 & 27.67 \\
\hline 21 & Hall, John & 5.56 & 6.00 & 5.63 & 4.86 & 5.22 & 27.27 \\
\hline 22 & Atkinson, Harry & 5.33 & 5.92 & 5.73 & 4.70 & 5.42 & 27.10 \\
\hline 23 & Stout, Robert & 5.55 & 6.09 & 5.20 & 5.10 & 4.73 & 26.67 \\
\hline 24 & Palmer, Geoffrey & 4.61 & 6.12 & 4.93 & 4.85 & 5.85 & 26.36 \\
\hline 25 & Shipley, Jenny & 5.43 & 5.41 & 5.46 & 5.14 & 4.55 & 25.99 \\
\hline 26 & Fox, William & 5.45 & 5.64 & 5.10 & 4.50 & 4.27 & 24.96 \\
\hline 27 & Moore, Mike & 5.33 & 5.90 & 5.10 & 4.74 & 3.74 & 24.81 \\
\hline 28 & Weld, Frederick & 5.33 & 4.67 & 4.13 & 5.38 & 4.89 & 24.40 \\
\hline 29 & Whitaker, Frederick & 4.11 & 5.44 & 4.43 & 3.88 & 3.89 & 21.75 \\
\hline 30 & Pollen, Daniel & 3.86 & 4.43 & 3.43 & 3.67 & 3.29 & 18.68 \\
\hline 31 & Domett, Alfred & 3.89 & 3.78 & 3.75 & 4.00 & 3.22 & 18.64 \\
\hline 32 & Forbes, George & 3.88 & 4.00 & 3.94 & 3.50 & 3.00 & 18.32 \\
\hline
\end{tabular}

The 2011 exercise produced similar results to the 1998 study. Once again, Seddon and Fraser took out the top two positions, although Seddon did not retain his top spot in both components of the survey. Whilst he gained the highest score overall in the performance categories, and subsequently gained the highest score in four out of the five categories, he was beaten out by Fraser in the overall appraisal, with only 70 per cent of respondents rating Seddon as outstanding compared to Fraser's 81 per cent. ${ }^{48}$

With the gap between Seddon and Fraser closing from what was observed in the 1998 exercise, the authors suggested that Fraser's prime ministership had gained 'enhanced

\footnotetext{
${ }^{48}$ See Jon Johansson and Stephen Levine. 'Evaluating Prime Ministerial Performance: The New Zealand Experience.' p. 302.
} 
attention', with more scholarly attention directed towards him. ${ }^{49}$ Furthermore, it was noted by the respondents that perceptions of Fraser were enhanced, with substantial comments from participants placing Fraser on a par with Seddon. ${ }^{50}$

The top five were rounded out with Savage in the third place position in both components of the exercise, and Helen Clark entering in fourth place - a noteworthy position for a new entrant in the exercise. Holyoake placed in the fifth place position for overall appraisal and in sixth place for performance categories. The authors noted the significance of Holyoake's placing as an anchor to understand and appreciate the high ranking of Clark, with Holyoake also being regarded highly in the 1998 exercise. ${ }^{51}$ Jim Bolger also ranked highly in the performance categories in the fifth place position; however his ranking was slightly lowered in the overall appraisal, placing $10^{\text {th }}$ with an overall score of 3.58 .

Once again, the bottom place holders consisted of Domett and Forbes, with Forbes taking out the bottom spot in both components of the survey. Forbes produced an overall ranking of 1.59 and a mean performance ranking of 18.32, despite having 17 responses returned that rated his time as Prime Minister. Mike Moore moved slightly up the rankings, placing in $27^{\text {th }}$ in both components of the exercise. Instead, the third to last place position was taken out by Daniel Pollen, a slight fall in his rankings from the initial 1998 exercise. $^{52}$

\footnotetext{
49 The authors noted the possible influence of scholarship on Peter Fraser in the time between the original exercise in 1998 and the replication in 2011. The works of both Margaret Clark in 1998 and Michael Bassett with Michael King in 2000 were both noted for their importance. See Margaret Clark (ed). 1998. Peter Fraser: Master Politician. Palmerston North: Dunmore and Michael Bassett with Michael King. 2000. Tomorrow Comes the Song: A Life of Peter Fraser. Auckland: Penguin. Johansson and Levine. 'Evaluating Prime Ministerial Performance: The New Zealand Experience.' p. 302.

${ }^{50}$ See Jon Johansson and Stephen Levine. 'Evaluating Prime Ministerial Performance: The New Zealand Experience'. p. 302.

${ }^{51}$ It is noted that both Holyoake and Clark proved to have similar Prime Ministerships, with both being 'long term prime ministers during politically stable and relatively prosperous economic times.' Both were also considered to be incrementalistic Prime Ministers, and highly competent and extremely effective managers. See Jon Johansson and Stephen Levine. 'Evaluating Prime Ministerial Performance: The New Zealand Experience.' p. 308.

${ }^{52}$ For further information on the 2011 rankings, please refer to Table 2.3 (results by overall appraisal of performance) and Table 2.4 (results by mean score of performance categories).
} 


\section{Leadership ranking scholarship in the United States}

As one of the most high-profile democracies, the United States (US) has made a significant contribution towards the exploration of leadership rankings, more so than any other country. Since 1948, a vast range of scholars, institutions, journalists and television networks have conducted a series of US Presidential ranking studies. Many of these studies have gone on to be repeated multiple times over past decades, with some being heavily cited across the globe, as well as influencing the undertaking of ranking exercises in other nations. ${ }^{53}$

Schlesinger Ranking Studies, 1948, 1962, 1996

The two ranking exercises conducted by Arthur Schlesinger in 1948 and 1962, subsequently followed by one conducted by his son Arthur Schlesinger Jr. in 1996, have gone on to define the further ranking studies that have been established within the United States. Furthermore, these studies have been used to heavily influence other studies that have occurred across the world, as witnessed in the exercises conducted by Sheppard and by Johansson and Levine.

In 1948, historian Arthur Schlesinger was approached by Life Magazine to conduct a survey ranking the performance of past US presidents. ${ }^{54}$ Upon its completion, Schlesinger produced the first ranking exercise of its kind known in the United States, contributing towards the richness of presidential history. To execute his study, Schlesinger polled a sample of 55 historians, asking them to judge each president's performance, and to place them in one of five categories: Great, Near Great, Average, Below Average and Failure. ${ }^{55}$ Two presidents, William Henry Harrison and James A. Garfield, were omitted from the exercise due to their deaths soon after taking office. ${ }^{56}$ Each participant was left to decide by themselves how they best judged presidential performance, and no guidelines or criteria were provided to aid rankings. Upon the publication of results, the exercise produced much excitement and interest, as no analysis of this kind involving presidential performance had been witnessed before. Following its success, Schlesinger was approached by The New York Times to repeat his initial exercise in 1962, and

\footnotetext{
${ }^{53}$ The Schlesinger, Siena Research Institute, C-Span, Wall Street Journal, and Rottinghaus and Vaughn studies have each been repeated by the authors or institutes multiple times.

${ }^{54}$ See Arthur M. Schlesinger Jr. 1997. 'Rating the Presidents: Washington to Clinton.' Political Science Quarterly. Vol. 112 (2). p. 179.

${ }_{55}^{5}$ See Arthur M. Schlesinger Jr. 1997. 'Rating the Presidents: Washington to Clinton.' p. 179.

${ }^{56}$ Ibid.
} 
his son, Arthur Schlesinger Jr., was approached by The New York Times in 1996 to replicate his father's study once more. ${ }^{57}$ The two subsequent polls were also successful and saw significant discussion and interest.

Each survey, despite the large differences in time between their execution, produced similar results. Abraham Lincoln consistently took out the number one spot, followed by George Washington and Franklin D. Roosevelt. Those presidents that were considered 'great' or 'near great' also remained the same, with only some slight variation in rankings over the three surveys. ${ }^{58}$ Likewise, the presidents deemed to be the worst, ranked as a 'failure' by participants, also continuously remained the same, with James Buchanan, Franklin Pierce, and Warren G. Harding always falling into the bottom three rankings. President Harding consistently took out the bottom place position in each survey.

Despite the interest and excitement the Schlesinger exercises brought forth, they did not do so without being accompanied by a significant amount of controversy. Many condemned the approach taken by Schlesinger in his original survey to only use a sample consisting of historians, stating that they had no place to make an informed judgement on the performance of those that have held office. ${ }^{59}$ Some of the harshest criticisms were made by former Presidents, including Dwight Eisenhower and John F. Kennedy, who served as president during the 1962 exercise, each arguing that the presidency can only best be experienced, rather than be explained. ${ }^{60}$ Schlesinger sent the 1962 study to President Kennedy to complete. He began to do so, but changed his mind after coming to the conclusion that the exercise was unprofitable. ${ }^{61}$ Kennedy later claimed that he could 'not imagine that the quality of the presidential experience could be understood by those who had not shared it' and said to Schlesinger Jr. that 'only the president himself can know what his real pressures and real

\footnotetext{
${ }^{57}$ See Arthur M. Schlesinger Jr. 1997. 'Rating the Presidents: Washington to Clinton.' p. 179.

${ }^{58}$ Presidents Thomas Jefferson, Andrew Jackson, Theodore Roosevelt, Woodrow Wilson, Harry Truman and James K. Polk were those that were continuously ranked as 'great' or 'near great' over the three exercises. See Arthur Schlesinger, 1948. 'Historians Rate the US Presidents.' Life. 25. (18): 65-66, Arthur Schlesinger, 1962. 'Our Presidents: Ratings by 75 Historians.' The New York Times, July. 12-13, 40-41, 43, and Schlesinger Jr. 'Rating the Presidents: Washington to Clinton.' p. 189.

${ }^{59}$ See Arthur M. Schlesinger Jr. 'Rating the Presidents: Washington to Clinton.' p. 180.

${ }^{60}$ See Arthur M. Schlesinger Jr. 'Rating the Presidents: Washington to Clinton.' p. 180, and R. Gordon Hoxie. 1977. Command Decision and the Presidency: A Study of National Security Policy and Organization. New York: Reader's Digest Press. p. 244-245.

${ }^{61}$ See Arthur M. Schlesinger Jr. 1965. A Thousand Days: John F. Kennedy in the White House. Boston: Houghton Mifflin. p. 674-675.
} 
alternatives are' ${ }^{62}$ Further objections were made later by Richard Nixon, who argued that whilst 'history would treat me fairly, historians would not, as they were mostly on the left'. ${ }^{63}$ Despite this, historians continued to be the only participants in each of the surveys, with Schlesinger Jr. continuing the tradition of polling historians in his 1996 assessment, following the approach taken by his father in the earlier studies.

In conjunction with the comments made about the participants in each of the Schlesinger exercises, there has also been discussion over the methodology of each survey. Many believe that the Schlesinger approach, in which each president is given an overall ranking, is too simplistic and allows for too many alternative meanings from respondents. ${ }^{64}$ Schlesinger Jr. addressed the notion in his 1996 study, noting that multiple studies had been undertaken since the initial survey in 1948, each of which displayed more extensive and complex methodologies. ${ }^{65}$ Despite this, Schlesinger Jr. noted that many of these rankings garnered near identical results to those seen in the original exercises, no matter how complex or simple the methodology. ${ }^{66}$ Regardless of the controversy that the Schlesinger polls have produced, it cannot be denied that they have gone on to shape many of the subsequent ranking exercises that have occurred in the United States, as well as influenced those that have since developed across the world.

\section{Other Ranking Studies}

In addition to the Schlesinger studies that have shaped the path for future research, various other exercises have also been carried out over the past century, contributing towards the expansion of knowledge of presidential performance. The Chicago Tribune completed an

\footnotetext{
${ }^{62}$ See Arthur M. Schlesinger Jr. 1965. A Thousand Days: John F. Kennedy in the White House. Boston: Houghton Mifflin. p. 674-675.

${ }^{63}$ As told to John Chancellor by Richard M. Nixon on Meet the Press, 10 April 1988. See Arthur M. Schlesinger Jr. 'Rating the Presidents: Washington to Clinton.' p. 180.

${ }^{64}$ It is noted by Gary Maranell, in his work on extending the Schlesinger polls, that a concern of the earlier polls was the 'possible alternative meanings and dimensions that may have been employed in the ratings of prestige'. In order to combat this, Maranell conducted an extension of the Schlesinger surveys and argued that by including additional dimensions of evaluation and the use of a larger and less biased sample, a crucial update was added to the initial Schlesinger methods and results, producing more viable results. Such a topic was also touched upon by Thomas A. Bailey in his book Presidential Greatness: The Image and the Man from George Washington to the Present, who discussed the polls and their inaccuracies of assessment. See Gary M. Maranell. 1970. 'The Evaluation of Presidents: An Extension of the Schlesinger Polls'. The Journal of American History. Vol. 57 (1). p. 104.

${ }^{65}$ See Arthur M. Schlesinger Jr. 'Rating the Presidents: Washington to Clinton.' p. 181.

${ }^{66}$ Ibid., p. 182.
} 
exercise in 1982, which was later used to influence the study conducted in New Zealand by Simon Sheppard. Using the first known methodology of its kind, the study adopted a multi questioned approach. ${ }^{67}$ Subsequently, the Siena Research Institute at Siena College in Loudonville has made a significant contribution towards the study of presidential performance. Conducted by various academics in 1982, 1990, 1994, 2002 and 2010, the Siena Research Institute surveys have also led to criticism, due to its extremely long and complex methodologies, with participants arguing that the survey was too time consuming to complete. ${ }^{68}$ Despite this, all five surveys have produced relatively similar results. Studies have also been carried out multiple times by the Wall Street Journal, and by television network $C$ Span, with results once again closely aligning with the Schlesinger studies. ${ }^{69}$ The studies compiled by Brandon Rottinghaus and Justin Vaughn are the most recent academic additions, with exercises being completed in 2015 and 2018. The Rottinghaus and Vaughn studies build upon the Schlesinger surveys, although with slight changes in methodology, and include assessment of the most recent Presidents to serve in office. ${ }^{70}$ The 2018 survey saw the current President, Donald Trump, enter in the last place position, despite having just begun his term in office. ${ }^{71}$ These exercises also saw the first academic assessment of Barack Obama, who entered rankings in $18^{\text {th }}$ place in the 2015 exercise and $8^{\text {th }}$ place in the subsequent study. ${ }^{72}$ Like the Schlesinger exercises, both Rottinghaus and Vaughn studies saw Abraham Lincoln enter in the number one position. ${ }^{73}$

\footnotetext{
${ }^{67}$ Respondents were asked to rank presidential performance based on the following categories: Leadership Qualities, Appointments, Accomplishments and Crisis Management, Character and Integrity and Political Skills. See Kenneth Janda, Jeffrey M. Berry, and Jerry Goldman (eds). The Challenge of Democracy: Government in America ( $3^{\text {rd }}$ Ed.). p. 443.

${ }^{68}$ The Siena Research Institute surveys asked participants to rank each president on a scale of 1 to 5 (with one being poor and five being outstanding) in the following 20 categories: Background, Party leadership, Communication ability, Relationship with Congress, Court appointments, Handling of U.S. economy, Luck, Ability to compromise, Willing to take risks, Executive appointments, Overall ability, Imagination, Domestic accomplishments, Integrity, Executive availability, Foreign policy accomplishments, Leadership ability, Intelligence, Avoid crucial mistakes and Present overall view. See Douglas A. Lonnstrom and Thomas O'Kelly. 'The Contemporary Presidency: Rating the Presidents: A Tracking Study.' Presidential Studies Quarterly, Vol. 33 (3). p. 626.

${ }^{69}$ See Douglas G. Brinkley, Edna Greene Medford and Richard Norton Smith. 2017. 'C-SPAN Survey on Presidents 2017.' C-Span, and James Taranto. 2005. 'Presidential Leadership: The Rankings.' 12 September. Wall Street Journal: New York.

${ }^{70}$ The Rottinghaus and Vaughn exercises asked participants to rank each president on a numerical scale of zero to one hundred, with zero representing failure, fifty representing average and one hundred representing great. See Brandon Rottinghaus and Justin Vaughn. 2018. 'Official Results of the 2018 Presidents and Executive Politics Presidential Greatness Survey.' Houston: University of Houston. p. 1.

${ }^{71}$ See Brandon Rottinghaus and Justin Vaughn. 2018. 'How Does Trump Stack Up Against the Best - and Worst - Presidents?'. 19 February. The New York Times.

${ }^{72}$ See Brandon Rottinghaus and Justin Vaughn. 'How Does Trump Stack Up Against the Best - and Worst Presidents?', and Brandon Rottinghaus and Justin Vaughn. 2015. 'Measuring Obama Against the Great Presidents.'. 15 February. Brookings: Washington D.C.

${ }^{73}$ Ibid.
} 
Table 2.5. Results of Presidential ranking studies in the United States

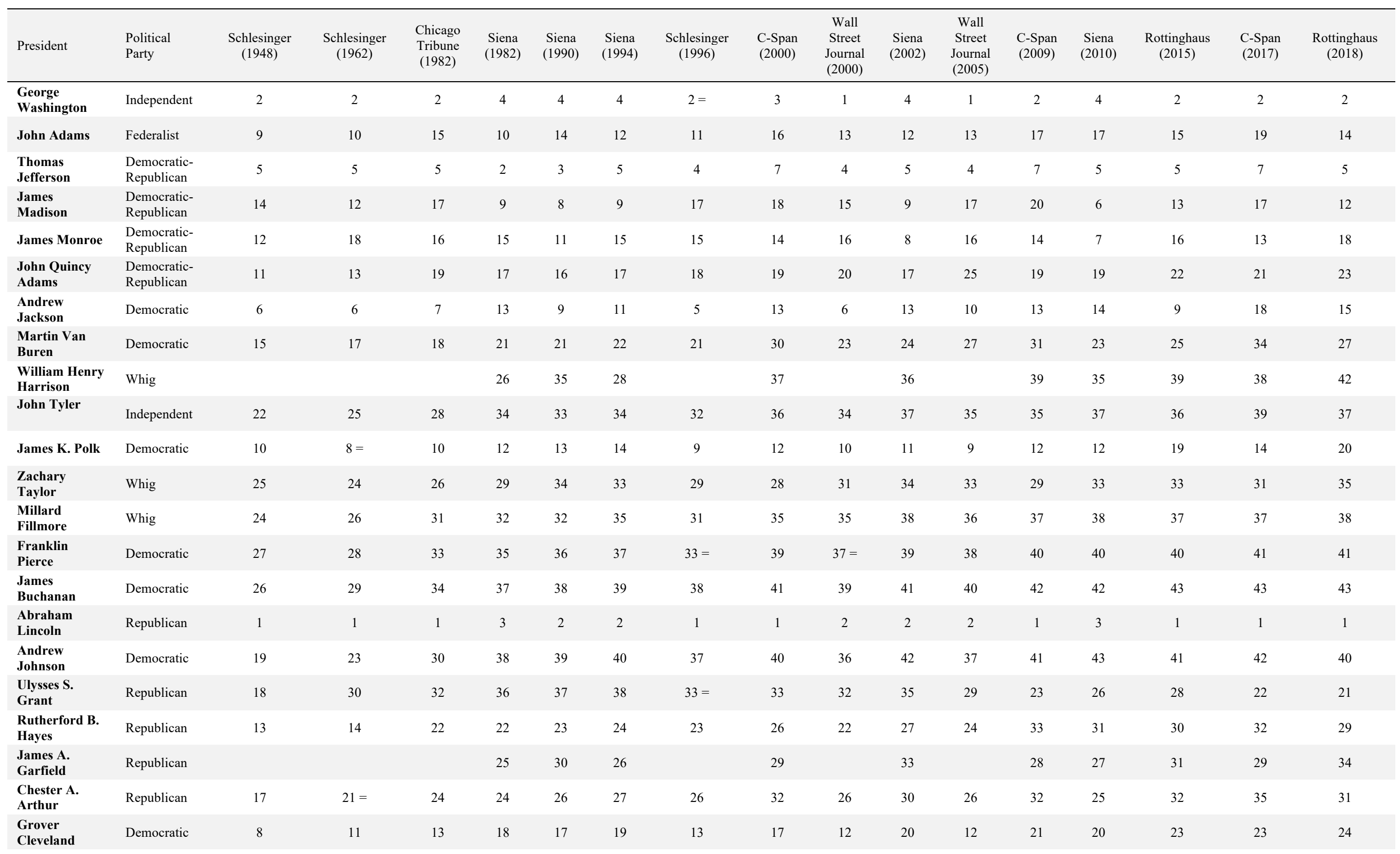




\begin{tabular}{|c|c|c|c|c|c|c|c|c|c|c|c|c|c|c|c|c|c|}
\hline President & $\begin{array}{l}\text { Political } \\
\text { Party }\end{array}$ & $\begin{array}{l}\text { Schlesinger } \\
\text { (1948) }\end{array}$ & $\begin{array}{l}\text { Schlesinger } \\
\text { (1962) }\end{array}$ & $\begin{array}{c}\text { Chicago } \\
\text { Tribune } \\
(1982) \\
\end{array}$ & $\begin{array}{c}\text { Siena } \\
(1982)\end{array}$ & $\begin{array}{l}\text { Siena } \\
(1990)\end{array}$ & $\begin{array}{l}\text { Siena } \\
(1994)\end{array}$ & $\begin{array}{l}\text { Schlesinger } \\
(1996)\end{array}$ & $\begin{array}{l}\text { C-Span } \\
(2000)\end{array}$ & $\begin{array}{c}\text { Wall } \\
\text { Street } \\
\text { Journal } \\
(2000)\end{array}$ & $\begin{array}{l}\text { Siena } \\
(2002)\end{array}$ & $\begin{array}{c}\text { Wall } \\
\text { Street } \\
\text { Journal } \\
(2005) \\
\end{array}$ & $\begin{array}{l}\text { C-Span } \\
(2009)\end{array}$ & $\begin{array}{l}\text { Siena } \\
(2010)\end{array}$ & $\begin{array}{l}\text { Rottinghaus } \\
\text { (2015) }\end{array}$ & $\begin{array}{l}\text { C-Span } \\
(2017)\end{array}$ & $\begin{array}{l}\text { Rottinghaus } \\
\quad \text { (2018) }\end{array}$ \\
\hline $\begin{array}{l}\text { Benjamin } \\
\text { Harrison }\end{array}$ & Republican & 21 & 20 & 25 & 31 & 29 & 30 & 19 & 31 & 27 & 32 & 30 & 30 & 34 & 29 & 30 & 32 \\
\hline $\begin{array}{l}\text { William } \\
\text { McKinley }\end{array}$ & Republican & 18 & 15 & 11 & 19 & 19 & 18 & 16 & 15 & 14 & 19 & 14 & 16 & 21 & 21 & 16 & 19 \\
\hline $\begin{array}{l}\text { Theodore } \\
\text { Roosevelt }\end{array}$ & Republican & 7 & 7 & 4 & 5 & 5 & 3 & 6 & 4 & 5 & 3 & 5 & 4 & 2 & 4 & 4 & 4 \\
\hline $\begin{array}{l}\text { William } \\
\text { Howard Taft }\end{array}$ & Republican & 16 & 16 & 20 & 20 & 20 & 21 & 22 & 24 & 19 & 21 & 20 & 24 & 24 & 20 & 24 & 22 \\
\hline $\begin{array}{l}\text { Woodrow } \\
\text { Wilson }\end{array}$ & Democratic & 4 & 4 & 6 & 6 & 6 & 6 & 7 & 6 & 11 & 6 & 11 & 9 & 8 & 10 & 11 & 11 \\
\hline $\begin{array}{l}\text { Warren G. } \\
\text { Harding }\end{array}$ & Republican & 29 & 31 & 36 & 39 & 40 & 41 & 39 & 38 & $37=$ & 40 & 39 & 38 & 41 & 42 & 40 & 39 \\
\hline $\begin{array}{l}\text { Calvin } \\
\text { Coolidge }\end{array}$ & Republican & 23 & 27 & 29 & 30 & 31 & 36 & 30 & 27 & 25 & 29 & 23 & 26 & 29 & 27 & 27 & 28 \\
\hline $\begin{array}{l}\text { Herbert } \\
\text { Hoover }\end{array}$ & Republican & 20 & 19 & 21 & 27 & 28 & 29 & $33=$ & 34 & 29 & 31 & 31 & 34 & 36 & 38 & 36 & 36 \\
\hline $\begin{array}{l}\text { Franklin D. } \\
\text { Roosevelt }\end{array}$ & Democratic & 3 & 3 & 3 & 1 & 1 & 1 & $2=$ & 2 & 3 & 1 & 3 & 3 & 1 & 3 & 3 & 3 \\
\hline $\begin{array}{l}\text { Harry S. } \\
\text { Truman }\end{array}$ & Democratic & & $8=$ & 8 & 7 & 7 & 7 & 8 & 5 & 7 & 7 & 7 & 5 & 9 & 6 & 6 & 6 \\
\hline $\begin{array}{l}\text { Dwight } \\
\text { Eisenhower }\end{array}$ & Republican & & $21=$ & 9 & 11 & 12 & 8 & 10 & 9 & 9 & 10 & 8 & 8 & 10 & 7 & 5 & 7 \\
\hline $\begin{array}{l}\text { John F. } \\
\text { Kennedy }\end{array}$ & Democratic & & & 14 & 8 & 10 & 10 & 12 & 8 & 18 & 14 & 15 & 6 & 11 & 14 & 8 & 16 \\
\hline $\begin{array}{l}\text { Lyndon B. } \\
\text { Johnson }\end{array}$ & Democratic & & & 12 & 14 & 15 & 13 & 14 & 10 & 17 & 15 & 18 & 11 & 16 & 12 & 10 & 10 \\
\hline Richard Nixon & Republican & & & 35 & 28 & 25 & 23 & 36 & 25 & 33 & 26 & 32 & 27 & 30 & 34 & 28 & 33 \\
\hline Gerald Ford & Republican & & & 23 & 23 & 27 & 32 & 28 & 23 & 28 & 28 & 28 & 22 & 28 & 24 & 25 & 25 \\
\hline Jimmy Carter & Democratic & & & 27 & 33 & 24 & 25 & 27 & 22 & 30 & 25 & 34 & 25 & 32 & 26 & 26 & 26 \\
\hline $\begin{array}{l}\text { Ronald } \\
\text { Reagan }\end{array}$ & Republican & & & & 16 & 22 & 20 & 25 & 11 & 8 & 16 & 6 & 10 & 18 & 11 & 9 & 9 \\
\hline $\begin{array}{l}\text { George H. W. } \\
\text { Bush }\end{array}$ & Republican & & & & & 18 & 31 & 24 & 20 & 21 & 22 & 21 & 18 & 22 & 17 & 20 & 17 \\
\hline Bill Clinton & Democratic & & & & & & 16 & 20 & 21 & 24 & 18 & 22 & 15 & 13 & 8 & 15 & 13 \\
\hline $\begin{array}{l}\text { George W. } \\
\text { Bush }\end{array}$ & Republican & & & & & & & & & & 23 & 19 & 36 & 39 & 35 & 33 & 30 \\
\hline Barack Obama & Democratic & & & & & & & & & & & & & 15 & 18 & 12 & 8 \\
\hline
\end{tabular}




\section{Leadership Ranking Scholarship in the rest of the world}

Whilst not as prevalent and influential as the scholarship seen in the United States, research involving leadership rankings has occurred in other nations. Interest in the subject is still limited; however, as traction towards political leadership scholarship begins to expand, leadership rankings are becoming more prominent. Over the past two decades the United Kingdom, Canada and Australia have begun to see an expansion of literature that relates to the comparative assessment of their former leaders, with varying degrees of success.

\section{United Kingdom}

As one of the great political powers in the past, the United Kingdom has seen the rise of some significant political leaders. However, despite this, there remains little research dated before the twenty-first century that explores the comparative success of former Prime Ministers of the UK, with most scholarship being developed over the past 20 years. A leading scholar on Prime Ministerial performance, Kevin Theakston, notes the lack of interest in the exploration of the performance of former leaders in the UK, and particularly in regard to those prime Ministers that served in office before World War I. ${ }^{74}$ Over the past two decades, however, the UK has seen seven exercises that have assessed the performance of former Prime Ministers, with only one of those looking at all former office holders, conducted by The Times in $2010 .^{75}$ Of these studies, three have been conducted by academics, whilst the rest have been conducted by news sources and magazines.

The first survey that ranked the performance of former Prime Ministers was conducted in 1991, by The Guardian. Unlike the surveys that followed it, this exercise was a small analysis of nine post-war Prime Ministers in a larger study focusing on the performance of Margaret Thatcher. The poll asked the opinions of 50 historians, political scientists and other

\footnotetext{
${ }^{74}$ See Kevin Theakston. 2013. 'Evaluating Prime Ministerial Performance: The British Experience.' In Paul Strangio, Paul 't Hart, \& James Walter (eds). Understanding Prime Ministerial Performance: Comparative Perspectives. Oxford: Oxford University Press. p. 222, and Kevin Theakston and Mark Gill. 2006. 'Rating $20^{\text {th }}$ Century British Prime Ministers.' The British Journal of Politics and International Relations. 8 (2). p. 196. ${ }^{75}$ In addition to the seven surveys that have been conducted, a subsequent exercise was also organised that ranked the performance of the former leaders of the Labour Party. In recent years, scholarship has arisen that has also assessed the performance of former deputy Prime Ministers. See Kevin Theakston and Mark Gill. 'Rating $20^{\text {th }}$-Century British Prime Ministers.' p. 197, and Jonathan Kirkup and Stephen Thornton. 2017. “"Everyone Needs a Willie” The Elusive Position of Deputy to the British Prime Minister.' British Politics. 12 (4).
} 
social scientists, and was considered to be a 'preliminary judgement by contemporary historians rather than a definitive assessment. ${ }^{976}$ Despite its limited scope, the study provided a stepping stone for the expanding scholarship on UK Prime Ministerial performance.

With two small studies of post-war Prime Ministers being conducted in 1999 and 2000, by the BBC and the British Politics Group (BPG), in which Winston Churchill was named the 'top' performing leader, the first academic-led survey was organised in 2004 by Kevin Theakston and Mark Gill at the University of Leeds. Seeking to produce a statistically significant exercise, Theakston and Gill used a large sample of participants compared to the smaller ones that past surveys had seen, and also included a greater number of Prime Ministers. ${ }^{77}$ Each participant was asked to rank all $20^{\text {th }}$-century UK Prime Ministers on a scale of zero to ten, with zero being highly unsuccessful and ten being highly successful. ${ }^{78}$ No criteria or benchmarks were given to participants on how to rank each Prime Minister, although it was made known that the survey was asking respondents to rank a Prime Minister's time in office as opposed to their full 'lifetime achievements' over their entire political career. ${ }^{79}$ A total of 258 questionnaires were distributed to academics of political science, history and other social sciences, with 139 being returned to the authors. ${ }^{80}$

The results of the 2004 study remained similar to the exercises that had been previously carried out, with the top five Prime Ministers in each of the earlier exercises remaining the same (although with some slight shuffling in terms of rankings). Clement Attlee gained the top spot, followed by Winston Churchill in second place. With the study being carried out to also assess the performance of the current Prime Minister of the time, the exercise saw Tony Blair enter in sixth place, despite having not finished his term in office.

In addition to assessing the performance of Prime Ministers, Theakston and Gill also noted a range of variables that may have influenced the results of the survey. Participants were first asked to identify how they would vote if there was an election tomorrow, in the hopes of

\footnotetext{
${ }^{76}$ The results of the exercise were published in the issue of The Guardian on 20 June 1991. See Kevin Theakston and Mark Gill. 'Rating 20 ${ }^{\text {th }}$-Century British Prime Ministers.' p. 194-195.

${ }^{77}$ The surveys conducted in 1999 by the BBC and in 2000 by the BPG were regarded by Theakston and Gill as producing statistically invalid results due to having small sample, and also both excluded Tony Blair. Theakston and Gill also note the lack of Prime Ministers assessed in the exercise organised by The Guardian. See Kevin Theakston and Mark Gill. 'Rating 20 ${ }^{\text {th }}$-Century British Prime Ministers.' p. 197.

${ }^{78}$ Ibid.

${ }^{79} \mathrm{Ibid}$

${ }^{80} \mathrm{Ibid}$.
} 
providing context for the results of the exercise. ${ }^{81}$ Furthermore, participants were also asked to identify their profession (as political scientist, historian, or other), their gender, age and party allegiance. ${ }^{82}$ Results were then analysed from each of these categories to determine any differences, of which significant ones were brought to light. Despite the low response rates by female academics $(n=12)$, Theakston and Gill identified that women were more likely to rate Thatcher higher than men were, as she tended to rank near the top of female academic responses but lower down in the males'. ${ }^{83}$ Furthermore, the importance of age was also observed in the case of Tony Blair, with respondents under 55 tending to rank him higher than those above the age of 55, who tended to rank Churchill higher. ${ }^{84}$ Such a trend has caused Theakston and Gill to question as to whether future exercises will see the fall of Churchill in future exercises as older academics leave the scene. ${ }^{85}$ Overall, the exercise was regarded as successful due to the large number of participants and the offering of significant conclusions regarding the performance of UK Prime Ministers.

Theakston and Gill followed up their initial study with an exercise conducted in 2010, replicating their 2004 methodology and assessing the performance of those Prime Ministers that had served following 1945. Once again, Clement Attlee took the top position; the later exercise saw the fall of Winston Churchill from second position to sixth. Such a decline reflects on the questions raised by Theakston and Gill in their initial exercise regarding the fall of Churchill as older academics retire. Whilst no further academic studies have occurred in the United Kingdom since this exercise, a subsequent survey was completed by The Times in 2010, assessing the performance of all former UK Prime Ministers, the first of any kind to do so.

\footnotetext{
${ }^{81}$ See Kevin Theakston and Mark Gill. 'Rating 20 $0^{\text {th }}$-Century British Prime Ministers.' p. 199.

${ }^{82}$ Ibid.

${ }^{83}$ Ibid., p. 201.

${ }^{84}$ Ibid.

${ }^{85}$ Ibid.
} 
Table 2.6. Results of Prime Ministerial ranking studies in the United Kingdom

\begin{tabular}{|c|c|c|c|c|c|c|c|c|}
\hline Prime Minister & Political Party & $\begin{array}{l}\text { Guardian } \\
\text { (1991) }\end{array}$ & $\begin{array}{l}\text { BBC } \\
\text { Poll } \\
(1999)\end{array}$ & $\begin{array}{l}\text { BPG } \\
\text { Poll } \\
(2000)\end{array}$ & $\begin{array}{l}\text { Theakston/ } \\
\text { Gill (2004) }\end{array}$ & $\begin{array}{l}\text { Francis } \\
\text { Beckett } \\
(2006)\end{array}$ & $\begin{array}{l}\text { Theakston/ } \\
\text { Gill (2010) }\end{array}$ & $\begin{array}{l}\text { The } \\
\text { Times } \\
(2010)\end{array}$ \\
\hline Robert Wapole & Whig & & & & & & & 9 \\
\hline $\begin{array}{l}\text { Spencer Compton (1st Earl } \\
\text { of Wilmington) }\end{array}$ & Whig & & & & & & & 51 \\
\hline Henry Pelham & Whig & & & & & & & 29 \\
\hline $\begin{array}{l}\text { Thomas Pelham-Holles (1st } \\
\text { Duke of Newcastle) }\end{array}$ & Whig & & & & & & & 41 \\
\hline $\begin{array}{l}\text { William Cavendish (4th } \\
\text { Duke of Devonshire) }\end{array}$ & Whig & & & & & & & 44 \\
\hline $\begin{array}{l}\text { John Stuart (3rd Earl of } \\
\text { Bute) }\end{array}$ & Tory & & & & & & & 46 \\
\hline George Grenville & Whig & & & & & & & 48 \\
\hline $\begin{array}{l}\text { Charles Watson-Wentworth } \\
\text { (2nd Marquess of } \\
\text { Rockingham) }\end{array}$ & Whig & & & & & & & 32 \\
\hline $\begin{array}{l}\text { William Pitt (1st Earl of } \\
\text { Chatham) }\end{array}$ & Whig & & & & & & & $16=$ \\
\hline $\begin{array}{l}\text { Augustus Fitzroy (3rd Duke } \\
\text { of Grafton) }\end{array}$ & Whig & & & & & & & 49 \\
\hline Frederick North & Tory & & & & & & & 50 \\
\hline $\begin{array}{l}\text { William Pelty (2nd Earl of } \\
\text { Shelburne) }\end{array}$ & Whig & & & & & & & 26 \\
\hline $\begin{array}{l}\text { William Cavendish-Bentinck } \\
\text { (3rd Duke of Portland) }\end{array}$ & Whig/Tory & & & & & & & $39=$ \\
\hline William Pitt the Younger & Whig/Tory & & & & & & & 4 \\
\hline Henry Addington & Tory & & & & & & & $39=$ \\
\hline William Grenville & Whig & & & & & & & 43 \\
\hline Spencer Perceval & Tory & & & & & & & $36=$ \\
\hline $\begin{array}{l}\text { Robert Jenkinson (2nd Earl } \\
\text { of Liverpool) }\end{array}$ & Tory & & & & & & & 19 \\
\hline George Canning & Tory & & & & & & & 31 \\
\hline $\begin{array}{l}\text { Frederick John Robinson } \\
\text { (1st Viscount Goderich) }\end{array}$ & Tory & & & & & & & 52 \\
\hline $\begin{array}{l}\text { Arthur Wellesley (1st Duke } \\
\text { of Wellington) }\end{array}$ & Tory & & & & & & & 24 \\
\hline Charles Grey & Whig & & & & & & & 8 \\
\hline $\begin{array}{l}\text { William Lamb (2nd } \\
\text { Viscount Melbourne) }\end{array}$ & Whig & & & & & & & 25 \\
\hline Robert Peel & Conservative & & & & & & & 6 \\
\hline John Russell & Whig/Liberal & & & & & & & 21 \\
\hline $\begin{array}{l}\text { Edward Smith Stanley (14th } \\
\text { Earl of Derby) }\end{array}$ & Conservative & & & & & & & 18 \\
\hline $\begin{array}{l}\text { George Hamilton-Gordon } \\
\text { (4th Earl of Aberdeen) }\end{array}$ & Pelitte & & & & & & & 42 \\
\hline $\begin{array}{l}\text { Henry John Temple (3rd } \\
\text { Viscount Palmerston) }\end{array}$ & Whig/Liberal & & & & & & & 13 \\
\hline Benjamin Disraeli & Conservative & & & & & & & 10 \\
\hline William Ewart Gladstone & Liberal & & & & & & & 3 \\
\hline $\begin{array}{l}\text { Robert Gascoyne-Cecil } \\
\text { (Lord of Salisbury) }\end{array}$ & Conservative & & 7 & 8 & 10 & 3 & & $11=$ \\
\hline
\end{tabular}




\begin{tabular}{|c|c|c|c|c|c|c|c|c|}
\hline Prime Minister & Political Party & $\begin{array}{l}\text { Guardian } \\
\text { (1991) }\end{array}$ & $\begin{array}{l}\text { BBC } \\
\text { Poll } \\
(1999) \\
\end{array}$ & $\begin{array}{l}\text { BPG } \\
\text { Poll } \\
(2000) \\
\end{array}$ & $\begin{array}{l}\text { Theakston/ } \\
\text { Gill (2004) }\end{array}$ & $\begin{array}{l}\text { Francis } \\
\text { Beckett } \\
(2006)\end{array}$ & $\begin{array}{l}\text { Theakston/ } \\
\text { Gill (2010) }\end{array}$ & $\begin{array}{l}\text { The } \\
\text { Times } \\
(2010) \\
\end{array}$ \\
\hline $\begin{array}{l}\text { Archibald Primrose (5th } \\
\text { Earl of Rosebery) }\end{array}$ & Liberal & & & & & & & 45 \\
\hline Arthur Balfour & Conservative & & 16 & 15 & 18 & 2 & & 30 \\
\hline Winston Churchill & Conservative & 4 & 1 & 1 & 2 & 4 & 6 & 1 \\
\hline Clement Attlee & Labour & 2 & 3 & 2 & 1 & 5 & 1 & 7 \\
\hline Anthony Eden & Conservative & 9 & 19 & 19 & 20 & 0 & 12 & 47 \\
\hline Harold MacMillian & Conservative & 3 & 6 & 5 & 5 & 4 & 4 & 15 \\
\hline Alec Douglas-Home & Conservative & 8 & 15 & 17 & 19 & 1 & 11 & $36=$ \\
\hline Harold Wilson & Labour & $5=$ & 10 & 7 & 9 & 3 & 5 & 20 \\
\hline Edward Heath & Conservative & $5=$ & 11 & 9 & 13 & 4 & 9 & 23 \\
\hline James Callaghan & Labour & 7 & 12 & 12 & 12 & 2 & 7 & 27 \\
\hline Margaret Thatcher & Conservative & 1 & 5 & 4 & 4 & 5 & 2 & 5 \\
\hline John Major & Conservative & & 17 & 16 & 15 & 1 & 8 & 28 \\
\hline Tony Blair & Labour & & & & 6 & 3 & 3 & $16=$ \\
\hline Gordon Brown & Labour & & & & & & 10 & $36=$ \\
\hline David Cameron & Conservative & & & & & & & \\
\hline Theresa May & Conservative & & & & & & & \\
\hline
\end{tabular}




\section{Canada}

In Canada the concept of analysing the comparative assessment of Prime Ministers proves uninteresting to most academics. ${ }^{86}$ As a result, surveying has mainly been left to journalists, which still produces a low interest rate. ${ }^{87}$ The attitude that surrounds a Prime Minister in Canada appears rather different to other nations, with most Canadian politicians being considered quiet and modest. Prime Ministers are rather considered on a general basis to be political fixers or problem solvers, as opposed to a great unifying figure. ${ }^{88}$ Despite this, there has still been slight development on the assessment of Prime Ministerial performance, with five studies being carried out in Canada over the past century.

The first ranking exercise conducted in Canada took place in 1964 and was carried out by Globe Magazine. Based upon the methods seen in the United States in the Arthur Schlesinger surveys, the exercise looked at the perceptions of 10 participants. The study was regarded as inconclusive, due to both issues with the methodology as well as the sample, with academics arguing that the participants selected were not representative enough of Canada as a whole. Of the 10 participants, nine were male and only one was female, resulting in lack of gender diversity. ${ }^{89}$ Furthermore, all the participants were from similar geographical areas, none of which represented the French speaking parts of Canada. ${ }^{90}$ In terms of the methodology, the survey took a near identical approach to the Schlesinger surveys, with participants being asked to rank the performance of each Prime Minister as either 'great', 'near great', 'adequate' or 'inadequate' ${ }^{91}$ Despite there being no criteria given to participants on how to rank Prime Ministers, some participants decided to use specific elements of performance to judge each office holder. $^{92}$

\footnotetext{
${ }^{86}$ See Norman Hillmer and Stephen Azzi. 2013. 'Evaluating Prime Ministerial Performance: The Canadian Experience.' In Paul Strangio, Paul 't Hart, \& James Walter (eds). Understanding Prime-Ministerial Performance: Comparative Perspectives. Oxford: Oxford University Press. p. 243.

${ }^{87}$ Ibid.

${ }^{88}$ Ibid., p. 242.

${ }^{89}$ Ibid. p. 246.

${ }^{90}$ Ibid.

${ }^{91}$ See Globe. 1964. 'Rating the Prime Ministers.' 18 July. p. 8-12.

92 Participants were known to be using factors such as longevity to determine their rankings, with one participant refusing to rank the performance of any Prime Minister who had served less than a certain amount of time in office. A participant also refused to rank any Prime Ministers, believing that none had served in office long enough to warrant a ranking, whilst another refused to rank the two last Prime Ministers, arguing that not enough time had passed since they had left office to determine a ranking. See Norman Hillmer and Stephen Azzi. 'Evaluating Prime Ministerial Performance: The Canadian Experience.' p. 246.
} 
Following the struggle of the Globe exercise, interest in comparative assessment dulled for thirty years, with no exercises being completed again until 1997. This exercise marked the first academic survey to take place and was organised by Norman Hillmer and J. L. Granatstein at Carleton University. The authors sought to generate interest and question the political history of Canada, as opposed to creating a strictly scientific exercise..$^{93}$ Twenty-six academics were invited to take part in the exercise, with the authors making sure that there was a balanced, more representative sample compared to what had been seen in the initial survey by Globe. ${ }^{94}$ Participants were asked to rank the performance of former Prime Ministers on a scale of one to ten (with one representing failure and ten representing outstanding). Whilst no selected criteria were given to participants to aid their rankings, they were encouraged to consider the electoral success, national unity, success in achieving policy goals and the leadership in cabinet, party and country of each Prime Minister when giving their judgement. ${ }^{95}$

The results of the 1997 exercise saw William King enter in the top position, with Sir John A. Macdonald and Sir Wilfred Laurier in second and third place respectively. ${ }^{96}$ The exercise provided a foundation for further academic research of the comparative assessment of Prime Ministers in Canada. Following its completion, a further exercise was conducted by the magazine Policy Options in 2003, before another academic exercise was completed in 2011. Once again organised by Norman Hillmer, with the support of Stephen Azzi, this survey sought to carry on from the initial 1997 exercise, although taking a far more complex approach. Unlike the initial survey, this exercise was broken into three parts. Firstly, participants were asked to give an overall appraisal of a Prime Minister's performance on a scale of one to five, with no criteria given to aid responses. ${ }^{97}$ Following this, participants were asked to assess performance in regard to performance categories, although this section was limited to Prime Ministers who had served longer than four years, dubbed 'long term Prime Ministers. ${ }^{98}$ Lastly, participants

\footnotetext{
93 See Norman Hillmer and Stephen Azzi. 'Evaluating Prime Ministerial Performance: The Canadian Experience.' p. 248.

94 The authors comprised a sample with a fairer gender balance, as well as including a better mix of both French-speaking and English-speaking Canadians of both junior and senior scholarly status. See Norman Hillmer and Stephen Azzi. 'Evaluating Prime Ministerial Performance: The Canadian Experience.' p. 248.

${ }^{95}$ See Norman Hillmer and J. L. Granatstein. 1997. 'Historians Rank the Best and Worst Canadian Prime Ministers.' Maclean's. 110 (16). p. 34-39.

96 Ibid.

${ }^{97}$ See Norman Hillmer and Stephen Azzi. 'Evaluating Prime Ministerial Performance: The Canadian Experience.' p. 255.

${ }^{98}$ Participants were asked to rank Prime Ministers using the following criteria: National Unity, the Economy, Domestic Issues (including Social Policy), Canada's Place in the World and Party Leadership. See Norman Hillmer and Stephen Azzi. 'Evaluating Prime Ministerial Performance: The Canadian Experience.' p. 255.
} 
were asked to expand on their rankings of the long term Prime Ministers by explaining what they believed to be their greatest successes and failures. ${ }^{99}$ As seen in the United Kingdom in the Theakston and Gill exercise in 2011, Hillmer and Azzi asked participants to give personal details in order to observe if this might have influenced participants' rankings. ${ }^{100}$ A total of 204 questionnaires were distributed to participants, with 115 being returned, resulting in the biggest sample of any Canadian survey to take place. ${ }^{101}$

Despite slight changes in order, the top three Prime Ministers in the 2011 exercise again consisted of Laurier, Macdonald and King. ${ }^{102}$ Hillmer and Azzi have since completed a third exercise in 2016, with the top three Prime Ministers also remaining the same, bar slight changes in order. ${ }^{103}$ The 2016 survey adopted the same methodology as in 2011, and elicited 123 responses from both academics and journalists, slightly more than in its predecessor. ${ }^{104}$

\footnotetext{
${ }^{99}$ See Norman Hillmer and Stephen Azzi. 'Evaluating Prime Ministerial Performance: The Canadian Experience.' p. 255.

${ }^{100}$ Participants were asked to identify their gender, age, place of residence and first language, their area of discipline, and their voting intentions for the upcoming federal election. See Norman Hillmer and Stephen Azzi. 'Evaluating Prime Ministerial Performance: The Canadian Experience.' p. 255.

${ }^{101}$ Ibid.

${ }^{102}$ See Norman Hillmer and Stephen Azzi. 2011. 'Canada's Best Prime Ministers: Maclean's Second Survey of Our Greatest Leaders Shows a New Number One, and Some Big Surprises.' 10 June. Maclean 's: Ottawa.

${ }^{103}$ See Norman Hillmer and Stephen Azzi. 2016. 'Ranking Canada's Best and Worst Prime Ministers.' 7

October. Maclean's: Ottawa

${ }^{104}$ Ibid.
} 
Table 2.7. Results of Prime Ministerial ranking studies in Canada

\begin{tabular}{|c|c|c|c|c|c|c|}
\hline Prime Minister & Political Party & $\begin{array}{l}\text { Globe } \\
(1964)\end{array}$ & $\begin{array}{l}\text { Hillmer and } \\
\text { Granatstein } \\
(1997)\end{array}$ & $\begin{array}{l}\text { Policy } \\
\text { Options } \\
(2003)\end{array}$ & $\begin{array}{l}\text { Hillmer } \\
\text { and Azzi } \\
(2011)\end{array}$ & $\begin{array}{l}\text { Hillmer } \\
\text { and Azzi } \\
(2016)\end{array}$ \\
\hline $\begin{array}{l}\text { Sir John A. } \\
\text { Macdonald }\end{array}$ & Liberal-Conservative & 1 & 2 & & 2 & 3 \\
\hline $\begin{array}{l}\text { Alexander } \\
\text { Mackenzie }\end{array}$ & Liberal & 5 & 11 & & 13 & 13 \\
\hline Sir John Abbott & Liberal-Conservative & 11 & 17 & & 19 & 20 \\
\hline Sir John Thompson & Liberal-Conservative & 9 & 10 & & 14 & 16 \\
\hline $\begin{array}{l}\text { Sir Mackenzie } \\
\text { Bowell }\end{array}$ & Conservative & 12 & 19 & & 21 & 21 \\
\hline Sir Charles Tupper & Conservative & 13 & 16 & & 18 & 19 \\
\hline Sir Wilfrid Laurier & Liberal & 2 & 3 & & 1 & 2 \\
\hline Sir Robert Borden & Conservative/Unionist & 4 & 7 & & 8 & 9 \\
\hline Arthur Meighen & Conservative & 10 & 14 & & 16 & 17 \\
\hline William King & Liberal & 3 & 1 & & 3 & 1 \\
\hline R.B. Bennett & Liberal & 6 & 12 & & 12 & 14 \\
\hline Louis St. Laurent & Liberal & 7 & 4 & 4 & 7 & 6 \\
\hline John Difenbaker & $\begin{array}{l}\text { Progressive- } \\
\text { Conservative }\end{array}$ & 8 & 13 & 6 & 10 & 12 \\
\hline Lester B. Pearson & Liberal & & 6 & 1 & 4 & 5 \\
\hline Pierre Trudeau & Liberal & & 5 & 3 & 5 & 4 \\
\hline Joe Clark & $\begin{array}{l}\text { Progressive- } \\
\text { Conservative }\end{array}$ & & 15 & 7 & 17 & 18 \\
\hline John Turner & Liberal & & 18 & 8 & 20 & 22 \\
\hline Brian Mulroney & $\begin{array}{l}\text { Progressive- } \\
\text { Conservative }\end{array}$ & & 8 & 2 & 9 & 8 \\
\hline Kim Campbell & $\begin{array}{l}\text { Progressive- } \\
\text { Conservative }\end{array}$ & & 20 & 9 & 22 & 23 \\
\hline Jean Chrétien & Liberal & & 9 & 5 & 6 & 7 \\
\hline Paul Martin & Liberal & & & & 15 & 15 \\
\hline Stephen Harper & Conservative & & & & 11 & 11 \\
\hline Justin Trudeau & Liberal & & & & & 10 \\
\hline
\end{tabular}




\section{Australia}

Interest in the comparative assessment of Prime Ministers in Australia has been limited. Whilst some research has taken place, it has frequently been regarded as unscientific, with exercises often encountering issues with sampling and failing to take personal biases into account. Like Canada, most ranking exercises that have occurred in Australia are limited to those completed by the media or journalists, with only one academic exercise being conducted, by Paul Strangio at Monash University in 2010.

The first ranking exercise of Australian Prime Ministers took place in 1992 by the Canberra Times. Three hundred political scientists and historians, at least one from every Australian University, were asked to nominate who they believed to be the five greatest Australian Prime Ministers. ${ }^{105}$ Of the 300 questionnaires that were distributed, 143 were returned. ${ }^{106}$ The criteria of how to judge greatness was left up to respondents. Despite a relatively high response rate, the survey was met with criticism, with many participants arguing that the exercise was unscientific and a waste of time. ${ }^{107}$ In particular, participants noted that they felt the question was too broad, and that a set of criteria needed to be provided in order to determine how to rank 'greatness'. ${ }^{108}$ The Canberra Times survey saw Ben Chifley take the top position, followed by John Curtin and Alfred Deakin. ${ }^{109}$

The 1992 exercise was followed by two further exercises, the first being conducted by the Australian Financial Review in 2001 and the second by Age magazine in 2004. Both surveys provided similar results to the initial study, with Chifley, Curtin and Deakin all entering in the top five of both surveys. ${ }^{110}$ Despite similar results, these surveys were regarded as slightly more successful than that of the Canberra Times, with little to no criticism from participants. The Age survey was regarded as having a slightly less unanimous result, as

\footnotetext{
${ }^{105}$ See Norman Abjorensen. 1992. ‘Australia’s Top 10 PM's.' 5 December. Canberra Times. p. 19. 106 Ibid.

${ }^{107}$ See Paul Strangio. 'Evaluating Prime Ministerial Performance: The Australian Experience.' In Paul Strangio, Paul 't Hart, \& James Walter (eds). Understanding Prime-Ministerial Performance: Comparative Perspectives. Oxford: Oxford University Press. p. 269.

108 Ibid.

${ }^{109}$ See Norman Abjorensen. 'Australia's Top 10 PM's.' p. 19.

${ }^{110}$ For further information, please refer to Table 2.8 (Results of Prime Ministerial Ranking Studies in Australia).
} 
respondents were asked to base their responses on a set of provided criteria. ${ }^{111}$ However, the results of the survey saw some respondents basing their responses along different sets of criteria than those provided, meaning that rankings between participants tended to differ slightly more than usual. ${ }^{112}$

The most recent exercise undertaken in Australia was conducted in 2010 by Paul Strangio at Monash University. As the first academic survey of its kind, this exercise has provided the foundations for further research in this field of political science. The Monash University exercise asked for the perceptions on prime ministerial leadership of 145 political scientists and historians who have specialised in areas of Australian politics and history. ${ }^{113}$ The survey asked respondents to rank Prime Ministers in two ways, first giving an overall appraisal of each Prime Minister's performance in office, and then ranking each in terms of performance categories. ${ }^{114}$ Of the initial 145 questionnaires that were distributed, 40 were returned to the author. Once again, the results of the survey placed Curtin and Deakin in the top three, with Bob Hawke in the second place position. ${ }^{115}$ The Monash University survey marked Hawke's highest ranking of all exercises, although he did gain the third place position in the exercise six years earlier. ${ }^{116}$

Despite a different methodology being used, and being the first academic survey of its kind, the Monash University exercise provided relatively similar results to its predecessors. It did not do so without criticism from participants, who argued that the survey was too time consuming and had too many complex categories that were hard to answer for many of the earlier Prime Ministers. ${ }^{117}$ Furthermore, it was argued that there were too many performance

\footnotetext{
111 The exercise suggested to participants that they base their responses on the following criteria: Leadership, Foreign Policy, Economic Management, Vision, Impact as an Agent of Change, and Relationship with the Electorate. See Michael Gordon and Michelle Grattan. 2004. 'Curtin: Our Greatest PM.' 18 December. Age. 112 Participants included different criteria, such as longevity and decisiveness, to aid their overall responses, which was said to alter the rankings of some Prime Minister compared to other responses. See Paul Strangio. 'Evaluating Prime Ministerial Performance: The Australian Experience.' p. 274.

113 Ibid., p. 276.

${ }^{114}$ Respondents were asked to give a ranking of each Prime Minister in the following categories: Management of Government, Party Leadership, Vision for Nation, Policy Legacy, Response to Governing Context, Economic Management, Management of Foreign Affairs, Management of Federal-State Relations, Communication Performance and Relationship with the Electorate. See Paul Strangio. 'Evaluating Prime Ministerial Performance: The Australian Experience.' p. 276.

115 Ibid., p. 279-280.

${ }^{116}$ See Michael Gordon and Michelle Grattan. 'Curtin: Our Greatest PM.' Age.

${ }^{117}$ See Paul Strangio. 'Evaluating Prime Ministerial Performance: The Australian Experience.’ p. 278.
} 
categories in general, as the survey required 23 former Prime Ministers to be ranked in each of these. ${ }^{118}$

Table 2.8. Results of Prime Ministerial Ranking Studies in Australia

\begin{tabular}{|c|c|c|c|c|c|c|}
\hline Prime Minister & Political Party & $\begin{array}{l}\text { Canberra } \\
\text { Times } \\
(1992)\end{array}$ & $\begin{array}{l}\text { Australian } \\
\text { Financial } \\
\text { Review: Best } \\
\text { PM's (2001) }\end{array}$ & $\begin{array}{l}\text { Australian } \\
\text { Financial } \\
\text { Review: } \\
\text { Worst PM's } \\
(2001)\end{array}$ & $\begin{array}{l}\text { Age } \\
(2004)\end{array}$ & $\begin{array}{l}\text { Monash } \\
\text { University } \\
(\mathbf{2 0 1 0})\end{array}$ \\
\hline $\begin{array}{l}\text { Sir Edmund } \\
\text { Barton }\end{array}$ & Protectionist & 11 & & 12 & & 10 \\
\hline Alfred Deakin & $\begin{array}{l}\text { Protectionist/ } \\
\text { Commonwealth Liberal }\end{array}$ & 3 & 1 & & & 3 \\
\hline $\begin{array}{l}\text { John (Chris) } \\
\text { Watson }\end{array}$ & Labor & 14 & & 9 & & 12 \\
\hline George Reid & Free Trade & & & $2=$ & & 19 \\
\hline And rew Fisher & Labor & 8 & $7=$ & 13 & & 7 \\
\hline Joseph Cook & Commonwealth Liberal & & & $4=$ & & 21 \\
\hline William Hughes & $\begin{array}{l}\text { Labor/ National-Labor/ } \\
\text { Nationalist }\end{array}$ & 6 & $7=$ & 8 & & 14 \\
\hline Stanley Bruce & Nationalist & 15 & 6 & $4=$ & & 15 \\
\hline James Scullin & Labor & 10 & & $2=$ & & 20 \\
\hline Joseph Lyons & United Australia & 13 & & 11 & & 11 \\
\hline Sir Earle Page & Country & & & & & \\
\hline Sir Robert Menzies & United Australia/Liberal & 5 & 2 & $\begin{array}{l}14(1939-41 \\
\text { term })\end{array}$ & 2 & 5 \\
\hline Arthur Fadden & Country & & & & & 22 \\
\hline John Curtin & Labor & 2 & 3 & & 1 & 1 \\
\hline Frank Forde & Labor & & & & & \\
\hline Ben Chifley & Labor & 1 & 4 & & 4 & 4 \\
\hline Harold Holt & Liberal & & & $4=$ & 10 & 18 \\
\hline John McEwen & Country & & & & & \\
\hline John Gorton & Liberal & 12 & & 10 & 9 & 16 \\
\hline William McMahon & Liberal & & & 1 & 11 & 23 \\
\hline Gough Whitlam & Labor & 4 & 5 & 7 & 6 & 6 \\
\hline Malcolm Fraser & Liberal & 9 & & & 8 & 13 \\
\hline Bob Hawke & Labor & 7 & $7=$ & & 3 & 2 \\
\hline Paul Keating & Labor & & 10 & & 7 & 8 \\
\hline John Howard & Liberal & & & & 5 & 9 \\
\hline Kevin Rudd & Labor & & & & & 17 \\
\hline Julia Gillard & Labor & & & & & \\
\hline Tony Abbott & Liberal & & & & & \\
\hline Malcolm Turnbull & Liberal & & & & & \\
\hline
\end{tabular}

${ }^{118}$ See Paul Strangio. 'Evaluating Prime Ministerial Performance: The Australian Experience.' p. 278. 


\section{Chapter Three: Methodology}

In order to fulfil my research aims, I organised a series of surveys designed to rank former New Zealand Prime Ministers. As displayed on a worldwide level, surveys appear to be the best way to gain information of this calibre. Whilst the idea of conducting qualitative interviews was suggested, I decided that it would be best to continue with the trend of surveying for quantitative data instead. The objective of this thesis is to investigate the changes that may arise from previous surveys conducted in New Zealand. Changing from quantitative to qualitative analysis would defeat such a purpose, and could garner extremely different results from what has been seen in New Zealand in the past. Moreover, due to the extremely small amount of existing scholarship, I felt that surveys also best allowed me to further explore this field of political science.

In order to best produce significant results, data needs to be gathered on as large a scale as possible, and surveys appear to be the best way to generate results. A simple survey, sent out to participants, which could be completed in their own time, was the most time efficient way to gather data from a sufficiently large sample.

Three surveys were conducted in order to gather data relevant to this topic. Each survey adopted a different methodology. The first two surveys were sent out to participants and followed on from the previous methods of data collection that have been seen in Prime Ministerial and Presidential rankings. ${ }^{119}$ Each survey was accompanied by an information sheet that was tailored to the methodology, giving the participants instructions on how the survey was to be completed. ${ }^{120}$ The surveys were emailed or hand delivered on 15 February 2018, and were returned by 15 March 2018. As opposed to interviews, surveys also allow the respondent to remain anonymous, a necessary option due to the high-profile status of some participants. Whilst anonymity can occur if interviews are held, a survey allows for data to be recorded in a more efficient manner. All participants had the option to remain anonymous.

\footnotetext{
119 See Appendices two and four for a copy of each survey

${ }^{120}$ See Appendices one and three for the information sheet that was provided with each survey
} 
In order to gather as much significant data as possible, 139 questionnaires were distributed to a sample consisting of academics in the fields of political science, international relations and history, alongside a range of journalists. ${ }^{121}$ In addition, the surveys were also distributed to the Association of Former Members of Parliament, allowing former MPs the opportunity to take part in this research. ${ }^{122}$ This sample was split in two, with half of the respondents receiving the exercise following the Sheppard and Johansson and Levine methodology, and the other half receiving questionnaires following the Schlesinger methodology. Following on from the approach taken in the Johansson and Levine exercise, current MPs were not included in the sample.

The first survey that was sent out was a replication of the study conducted by Simon Sheppard in 1998 and subsequently by Jon Johansson and Stephen Levine in 2011. This survey is the only known survey to have been conducted that formally ranks New Zealand Prime Ministers and was the inspiration for the further research carved out for this thesis. This survey takes on a multi-question format, firstly asking participants to rank each Prime Minister in five categories on a scale from 1-10 (with 1 being the worst, and 10 being the highest). ${ }^{123}$ Each participant was given explanatory information for each category when they received the survey. The five categories and their explanations were given to participants as seen below, following on from what has been in the previous exercises that have been undertaken.

- Leadership Qualities - how effective the Prime Minister was in motivating and inspiring the nation, bringing the people behind a legislative agenda, and winning an election.

- Parliamentary Skills - how effective the Prime Minister was in maintaining a parliamentary majority, dominating the opposition in parliament, setting the agenda in debate and 'question time', and managing news media coverage.

\footnotetext{
${ }^{121}$ See Appendix six for a full list of participants to whom surveys were distributed.

${ }^{122}$ These surveys were distributed by the convenor of the Association of Former Members of Parliament instead of participants being directly contacted. Therefore, the exact number of surveys distributed amongst the association is unknown.

${ }^{123}$ The five categories were as follows; Legislative Achievement, Party Management, Crisis Management, Leadership Qualities and Parliamentary Skills. See Simon Sheppard. 'Ranking New Zealand's Prime Ministers.' p. 75 .
} 
- Party Management - how effective the Prime Minister was in maintaining unity and purpose in their parliamentary caucus and cabinet, handling caucus dissent, and managing their relationship with the wider party organisation.

- Crisis Management - how effective the Prime Minister was in responding to unexpected developments (economic, political, military, natural disaster, and so on).

- Legislative Achievements - an assessment of the legacy for which the Prime Minister is responsible: the extent to which their term in office was a catalyst for positive change in New Zealand politics, economy and society.

Participants were also asked to give an overall appraisal of each Prime Minister, on an A-E scale (with A being outstanding and E being failure). In addition to these rankings, respondents were given the chance to answer two optional questions. The first asked for comments on their 'top' prime minister. The second asked who they believed to be the 'best prime minister New Zealand never had'. If participants chose to remain anonymous, they were asked to disregard the optional questions so there was no chance of being recognised.

The second survey that was sent out replicated the methodology that appeared in the Schlesinger ranking studies in the United States. Unlike the first survey, this instead adopted a single-question approach. Participants were asked to rank Prime Ministers on an overall scale, ranging from 'great' to 'failure'. The survey was slightly modified from its original form, also asking for optional comments of ones chosen 'top' Prime Minister. A survey of this nature has never been conducted in New Zealand, hence its inclusion in this research. The same anonymity clauses applied to this survey, with participants asked to refrain from completing optional questions to avoid identification.

Each survey provided guidelines for participants regarding the selection of Prime Ministers to be ranked for the survey. Participants were given a list of 34 Premiers and Prime Ministers to rank. Participants were also notified that Prime Ministers that had either served less than six months in office or had never fought an election were excluded from the survey in order to accurately replicate past exercises, and to simplify the questionnaires for 
participants. ${ }^{124}$ Furthermore, the current Prime Minister, Jacinda Ardern, was also excluded from the survey, as has been seen in previous exercises. ${ }^{125}$ Due to this clause, the following Premiers and Prime Ministers were excluded from this exercise.

Table 3.1. Premiers/Prime Ministers with less than six months in office or who never fought an election

\begin{tabular}{lll}
\hline Premier/Prime Minister & Period in office & Duration \\
\hline Henry Sewell & 7-20 May 1856 & 14 Days \\
George Waterhouse & 11 October 1872- 3 March 1873 & 144 Days \\
William Hall-Jones & 21 June 1906- 6 August 1906 & 47 Days \\
Thomas Mackenzie & 28 March 1912- 10 July 1912 & 105 Days \\
Francis Dillon Bell & 10 May 1925- 30 May 1925 & 21 Days
\end{tabular}

A third survey conducted purely for testing recall rates of participants was conducted in person at Victoria University of Wellington. ${ }^{126}$ This survey was also used to assess the possibility of generational shifts having an impact on results, with participants being mainly limited to the 18-25 age range. This survey remained fully anonymous, with no identifying elements for any written responses. Approximately 250 students at Victoria University of Wellington were surveyed across a range of undergraduate and postgraduate political science courses specialising in New Zealand politics. ${ }^{127}$ Unlike the first two surveys, this survey only consisted of two compulsory questions and one optional question, designed to test the recall rate of New Zealand political history. Participants were asked to name who they believed to be the best and the worst New Zealand Prime Ministers. Following this, they were given the option to provide reasons as to why they had chosen their selected Prime Ministers. Unlike the two larger surveys, participants were not given a list of those who had served in office, an intentional restriction designed to help test the recall rates of respondents. This survey was also conducted for a selected course twice, once at the beginning of trimester 1 (2018), and then

\footnotetext{
${ }^{124}$ Former Prime Minister Mike Moore was included on the ranking list, despite having served less than six months in office. However, due to the fact that he fought an election, albeit unsuccessfully, he was still eligible to be included in this exercise. Also included in this exercise is William Fox, due to serving multiple terms in office that totalled more than six months, despite the fact that his first term was only 14 days long.

${ }^{125}$ See Simon Sheppard. 'Ranking New Zealand's Prime Ministers. p. 77, and Jon Johansson and Stephen Levine. 'Evaluating Prime Ministerial Performance: The New Zealand Experience.' p. 301.

${ }^{126}$ See Appendix five for a copy of the survey.

${ }^{127}$ The three courses that the survey was administered across at Victoria University were Pols 111: Introduction to New Zealand Government and Politics; Pols 353: Growing Pains: New Zealand Politics between 1975 and present; and Pols 428: Parliamentary Internship Programme.
} 
again at the end of the trimester following the teaching of the course. ${ }^{128}$ The first round of surveys was administered in early March 2018, and the final round in June 2018.

${ }^{128}$ Because of the large sample size of Pols 111 (approximately 200) and the limited amount of time available to administer the survey, this class was excluded from being retested at the conclusion of the trimester and was instead used to simply test generational perceptions of New Zealand Prime Ministers. Subsequently, the same exclusion was applied to Pols 428 , but instead due to the extremely small sample (nine). Pols 353 was the only course that was tested at both the beginning and end of the trimester, to identify as to whether there was a shift in results following the students benefitting from more information over time. 


\section{Chapter Four: Data and Analysis}

\section{The initial responses}

Of the initial 139 questionnaires that were distributed, an overall total of 28 responses were completed and returned across the two surveys. A further two questionnaires were also returned but provided unusable data. ${ }^{129}$ The majority of these were returned by political science academics, although the perspectives of historians, journalists and members of the Association of Former Members of Parliament also contributed to the final sample. The survey that modelled the Sheppard and Johansson and Levine methodology received a total of 16 returned questionnaires, although this included the two responses that provided unusable data, bringing the count of total usable questionaries to 14 . The replication of the Schlesinger methodology bought forth 14 completed responses, rounding out the total of the 30 overall returned questionnaires.

Unlike the Sheppard and Johansson and Levine surveys that had taken place previously, the 2018 study achieved a smaller number of responses overall, with only 16 responses returned from the initial 69 that were sent out to participants. ${ }^{130}$ Furthermore, the replication of the Schlesinger study also bought forth a relatively small number of responses, with only 14 being returned from the initial 70 that were distributed. Sheppard's 1998 study produced 30 responses from the initial 75 questionnaires that were sent. ${ }^{131}$ In contrast, the 2011 exercise had 46 responses of the initial 245 questionnaires returned for a response rate of $18 \% .{ }^{132}$ The surveys that were returned have produced reliable and feasible data that have allowed the author to produce significant results, and despite the smaller number of responses returned to the researcher, the two surveys combined produced an overall response rate of $23 \%$.

\footnotetext{
${ }^{129}$ Some further surveys were received subsequent to the cut-off date, but their data has not been included in this research.

${ }^{130}$ For the purpose of this thesis, this survey will be referred to as the 2018 study. The surveys following the methodology of the Schlesinger surveys will be known as the Schlesinger replication.

${ }^{131}$ See Simon Sheppard. 'Ranking New Zealand's Prime Ministers.' p. 77.

132 See Jon Johansson and Stephen Levine. 'Evaluating Prime Ministerial Performance: The New Zealand Experience.' p. 301.
} 


\section{Calculation of results}

As previously mentioned, the surveys were divided and distributed under three different sets of methodology. However different the methodology proved, the surveys were calculated as similarly as possible in order to produce the most accurate results.

The results of the replication of studies produced by Sheppard and Johansson and Levine were calculated in the exact same way as what had been previously done in 1998 and 2011. Firstly, respondents were asked to give a ranking of 1-10 in five different categories. These numbers were then added up and divided by the number of responses for each Prime Minister in each category in order to provide each Prime Minister with a mean 'average' score for each category. By giving each Prime Minister a mean score as opposed to a tallied-up number, it allowed an even balance between those who were mentioned in every survey and those who were less frequently given a ranking. Once the mean score for each category was calculated, they were then added together to give each Prime Minister an overall score for each of the five categories.

Following this, respondents were asked to give each Prime Minister an overall ranking on a scale of A-E (with A being outstanding, E being failure). When calculating the results for this part of the survey, each letter was assigned a corresponding number. Those Prime Ministers given an 'A' ranking were assigned five points, whereas those given an ' $E$ ' were assigned one point. Each ranking from each survey was totalled up, and the final score of points was then divided by the number of rankings for each Prime Minister to form an overall score. Both overall scores have been displayed individually in two different tables, one representing rankings by categories and the other representing overall rankings.

Unlike the replication of the Sheppard and Johansson and Levine studies, the survey that replicated the Schlesinger methodology was able to be calculated in one overall table, as opposed to two different subsections. This particular survey has been calculated in the same way as the overall appraisal of Prime Ministers in the Sheppard and Johansson and Levine studies. The rankings of 'great' to 'failure' were assigned a corresponding number (from 5 to 1). The scores were totalled and divided by the number of mentions to give an overall mean. In the United States, the Schlesinger surveys were calculated in the same way, although the rankings were given the numbers of $4,3,2,1$ and -2 instead. However, due to the smaller 
sample size and the lack of mentions for some Prime Ministers, having -2 represent the failure category caused some of the overall mean scores to fall under the value of zero. In order to properly contrast this survey with the results of the Sheppard and Johansson and Levine studies, each survey was assigned the same values so as to produce statistically meaningful results.

The 2018 study: A replication of the Sheppard (1998) and Johansson and Levine (2011) methodology

Table 4.1. Results of 2018 survey by overall appraisal of performance

\begin{tabular}{|c|c|c|c|c|c|c|c|c|c|}
\hline Rank & Prime Minister & A & $\mathrm{B}$ & $\mathrm{C}$ & $\mathrm{D}$ & $\mathrm{E}$ & $\begin{array}{l}\text { Total } \\
\text { Score }\end{array}$ & Mentions & Mean \\
\hline \multirow[t]{2}{*}{$1=$} & Fraser, Peter & 35 & 8 & & & & 43 & 9 & 4.78 \\
\hline & Savage, Michael & 35 & 8 & & & & 43 & 9 & 4.78 \\
\hline 3 & Seddon, Richard & 30 & 8 & & & & 38 & 8 & 4.75 \\
\hline 4 & Kirk, Norman & 30 & 20 & & & & 50 & 11 & 4.55 \\
\hline 5 & Clark, Helen & 40 & 20 & 3 & & & 63 & 14 & 4.50 \\
\hline 6 & Vogel, Julius & 5 & 12 & & & & 17 & 4 & 4.25 \\
\hline \multirow[t]{2}{*}{$7=$} & Holyoake, Keith & 10 & 32 & & & & 42 & 10 & 4.20 \\
\hline & Massey, William & 10 & 8 & 3 & & & 21 & 5 & 4.20 \\
\hline \multirow[t]{4}{*}{$9=$} & Ballance, John & 5 & 12 & 3 & & & 20 & 5 & 4.00 \\
\hline & Lange, David & 15 & 32 & 9 & & & 56 & 14 & 4.00 \\
\hline & Stafford, Edward & & 8 & & & & 8 & 2 & 4.00 \\
\hline & Stout, Robert & & 12 & & & & 12 & 3 & 4.00 \\
\hline 13 & Key, John & 10 & 36 & 9 & & & 55 & 14 & 3.93 \\
\hline 14 & Ward, Joseph & & 12 & 3 & & & 15 & 4 & 3.75 \\
\hline 15 & Bolger, Jim & & 40 & 9 & 2 & & 51 & 14 & 3.64 \\
\hline 16 & Holland, Sidney & 5 & 12 & 15 & & & 32 & 9 & 3.56 \\
\hline 17 & Muldoon, Robert & 5 & 32 & 9 & 2 & 1 & 49 & 14 & 3.50 \\
\hline 18 & Coates, Gordon & & 8 & 9 & & & 17 & 5 & 3.40 \\
\hline 19 & Weld, Frederick & & 4 & 6 & & & 10 & 3 & 3.33 \\
\hline 20 & Atkinson, Harry & & 8 & 3 & 2 & & 13 & 4 & 3.25 \\
\hline 21 & Nash, Walter & 5 & 4 & 9 & 4 & & 22 & 7 & 3.14 \\
\hline 22 & English, Bill & & 8 & 33 & 2 & & 43 & 14 & 3.07 \\
\hline \multirow[t]{3}{*}{$23=$} & Domett, Alfred & & & 6 & & & 6 & 2 & 3.00 \\
\hline & Grey, George & & 8 & 3 & & 1 & 12 & 4 & 3.00 \\
\hline & Hall, John & & 4 & 9 & 2 & & 15 & 5 & 3.00 \\
\hline 26 & Palmer, Geoffrey & & 12 & 21 & 4 & 1 & 38 & 13 & 2.92 \\
\hline 27 & Marshall, John & & 4 & 9 & 4 & & 17 & 6 & 2.83 \\
\hline 28 & Rowling, Wallace & & 8 & 12 & 10 & & 30 & 11 & 2.73 \\
\hline 29 & Whitaker, Frederick & & & 3 & 2 & & 5 & 2 & 2.50 \\
\hline \multirow[t]{2}{*}{$30=$} & Moore, Mike & & 4 & 18 & 10 & 2 & 34 & 14 & 2.43 \\
\hline & Shipley, Jenny & & 4 & 18 & 10 & 2 & 34 & 14 & 2.43 \\
\hline 32 & Fox, William & & & 6 & 2 & 1 & 9 & 4 & 2.25 \\
\hline 33 & Pollen, Daniel & & & & 4 & & 4 & 2 & 2.00 \\
\hline \multirow[t]{2}{*}{34} & Forbes, George & & & & 6 & 2 & 8 & 5 & 1.60 \\
\hline & Average & & & & & & & & 3.45 \\
\hline
\end{tabular}


When observing the results of the 2018 study, interesting trends can be noted. Michael Joseph Savage tops both components of the survey, with the top overall score for categories and the top mark for the overall appraisal section, albeit sharing an equal placing with Peter Fraser in this section. Peter Fraser drops in terms of the overall score for categories, coming in $5^{\text {th }}$ place in contrast to his $2^{\text {nd }}$ place position in the 2011 exercise. Savage holds an almost three-point margin for his top placing in the overall score for categories section, whereas the $2^{\text {nd }}$ to $5^{\text {th }}$ place holders have less than a point between them. Helen Clark follows Savage in second place, with Richard Seddon trailing very closely behind.

In an unexpected move, Sir Keith Holyoake rises into the top five in $4^{\text {th }}$ place, with an overall mean score of 39.04. In contrast to the overall appraisal section, Holyoake shares the $7^{\text {th }}$ equal position with William Massey. Both Richard Seddon and Helen Clark maintain their top 5 status in the overall appraisal section, entering in $3^{\text {rd }}$ and $5^{\text {th }}$ place respectively, only to be broken up by Norman Kirk in $4^{\text {th }}$ place.

When looking at the lowest ranked Prime Ministers in the 2018 study, George Forbes takes out the lowest placing in both components of the survey, with an overall mean of 21.30 for category rankings and 1.60 for overall appraisal. William Fox and Daniel Pollen both fall into the bottom three Prime Ministers, faring not a lot higher than Forbes. Mike Moore is the most recent Prime Minister to be included in the lowest rankings of former office holders, with a $4^{\text {th }}$ to last placing in both components, although he does share his ranking in the overall appraisal section with Jenny Shipley.

Six Prime Ministers in the 2018 study received three or less mentions. These tended to be earlier serving Prime Ministers, where less knowledge of their time in office by respondents may be a prevailing factor as to why such a lack of responses has occurred. In contrast, the most recent serving Prime Ministers of the past three decades, namely Bill English, John Key, Helen Clark, Jenny Shipley, Jim Bolger and Mike Moore were mentioned in every response received. 
Table 4.2. Results of 2018 survey by mean score of performance categories

\begin{tabular}{|c|c|c|c|c|c|c|c|c|}
\hline Rank & Prime Minister & $\begin{array}{l}\text { Mean } \\
\text { Leadership } \\
\text { Qualities }\end{array}$ & $\begin{array}{l}\text { Mean } \\
\text { Parliamentary } \\
\text { Skills }\end{array}$ & $\begin{array}{l}\text { Mean Party } \\
\text { Management }\end{array}$ & $\begin{array}{l}\text { Mean Crisis } \\
\text { Management }\end{array}$ & $\begin{array}{l}\text { Mean } \\
\text { Legislative } \\
\text { Achievements }\end{array}$ & Overall Mean & $\begin{array}{l}\text { Ranking change } \\
\text { from Johansson and } \\
\text { Levine } 2011\end{array}$ \\
\hline 1 & Savage, Michael & 8.40 & 8.11 & 7.88 & 8.69 & 9.00 & 42.07 & +2 \\
\hline 2 & Clark, Helen & 7.93 & 8.00 & 8.57 & 7.50 & 7.29 & 39.29 & +2 \\
\hline 3 & Seddon, Richard & 7.94 & 7.81 & 7.79 & 7.43 & 8.13 & 39.09 & -2 \\
\hline 4 & Holyoake, Keith & 8.20 & 8.20 & 8.00 & 7.39 & 7.25 & 39.04 & +2 \\
\hline 5 & Fraser, Peter & 8.00 & 8.00 & 7.38 & 7.50 & 8.11 & 38.99 & -3 \\
\hline 6 & Massey, William & 6.20 & 9.20 & 7.40 & 7.90 & 6.80 & 37.50 & +3 \\
\hline 7 & Kirk, Norman & 8.17 & 7.82 & 7.40 & 6.55 & 7.45 & 37.38 & $N C$ \\
\hline 8 & Vogel, Julius & 7.00 & 7.20 & 6.40 & 6.80 & 9.80 & 37.20 & +2 \\
\hline 9 & Key, John & 7.75 & 7.46 & 8.18 & 7.39 & 6.07 & 36.86 & New entrant \\
\hline 10 & Ballance, John & 6.60 & 7.20 & 7.40 & 8.25 & 7.40 & 36.85 & -2 \\
\hline 11 & Lange, David & 7.64 & 8.36 & 5.57 & 6.21 & 8.00 & 35.79 & +2 \\
\hline 12 & Muldoon, Robert & 7.00 & 8.14 & 7.43 & 6.29 & 5.86 & 34.71 & -1 \\
\hline 13 & Stafford, Edward & 7.00 & 7.00 & 7.00 & 7.00 & 6.50 & 34.50 & +2 \\
\hline 14 & Holland, Sidney & 7.00 & 7.00 & 7.00 & 7.25 & 6.00 & 34.25 & -2 \\
\hline \multirow{2}{*}{$15=$} & Bolger, Jim & 6.64 & 7.07 & 6.46 & 6.43 & 6.89 & 33.50 & -10 \\
\hline & Stout, Robert & 6.50 & 6.67 & 6.50 & 6.50 & 7.33 & 33.50 & +9 \\
\hline 17 & Ward, Joseph & 6.25 & 7.00 & 6.67 & 6.25 & 6.33 & 32.50 & $N C$ \\
\hline 18 & Nash, Walter & 6.14 & 6.71 & 6.36 & 6.43 & 5.94 & 31.58 & -4 \\
\hline \multirow[t]{2}{*}{$19=$} & English, Bill & 5.50 & 6.54 & 6.64 & 6.39 & 5.50 & 30.57 & New entrant \\
\hline & Marshall, John & 6.00 & 6.50 & 6.17 & 6.40 & 5.50 & 30.57 & $N C$ \\
\hline 21 & Palmer, Geoffrey & 5.15 & 6.77 & 5.62 & 5.62 & 6.92 & 30.08 & +4 \\
\hline 22 & Coates, Gordon & 5.80 & 6.50 & 5.60 & 5.25 & 6.00 & 29.15 & -7 \\
\hline 23 & Rowling, Wallace & 5.27 & 6.27 & 6.18 & 5.64 & 5.73 & 29.09 & -6 \\
\hline 24 & Weld, Frederick & 5.33 & 6.00 & 7.00 & 5.50 & 5.00 & 28.83 & +5 \\
\hline 25 & Atkinson, Harry & 6.25 & 6.50 & 6.00 & 5.33 & 4.50 & 28.58 & -4 \\
\hline 26 & Shipley, Jenny & 5.50 & 6.00 & 5.86 & 5.71 & 5.07 & 28.14 & -1 \\
\hline \multirow[t]{2}{*}{$27=$} & Domett, Alfred & 6.00 & 6.00 & 6.00 & 5.00 & 5.00 & 28.00 & +5 \\
\hline & Whitaker, Frederick & 5.00 & 6.00 & 6.50 & 5.00 & 5.50 & 28.00 & +2 \\
\hline 29 & Hall, John & 5.80 & 6.00 & 5.00 & 4.50 & 6.50 & 27.80 & -9 \\
\hline 30 & Grey, George & 5.50 & 6.25 & 5.67 & 5.00 & 4.67 & 27.08 & -10 \\
\hline 31 & Moore, Mike & 5.21 & 6.00 & 5.43 & 5.14 & 4.07 & 25.86 & -5 \\
\hline 32 & Pollen, Daniel & 4.00 & 5.00 & 6.00 & 5.00 & 3.00 & 23.00 & $N C$ \\
\hline 33 & Fox, William & 4.25 & 6.00 & 3.50 & 4.00 & 5.00 & 22.75 & -8 \\
\hline 34 & Forbes, George & 3.80 & 5.00 & 4.80 & 4.20 & 3.50 & 21.30 & $N C$ \\
\hline
\end{tabular}


Table 4.3. Results of 2018 survey following the Schlesinger method

\begin{tabular}{|c|c|c|c|c|c|c|c|c|c|}
\hline Rank & Prime Minister & Great & $\begin{array}{l}\text { Near } \\
\text { Great }\end{array}$ & Average & $\begin{array}{c}\text { Below } \\
\text { Average }\end{array}$ & Failure & $\begin{array}{l}\text { Total } \\
\text { Score }\end{array}$ & Mentions & Mean \\
\hline 1 & Savage, Michael & 50 & 8 & 3 & & & 61 & 13 & 4.69 \\
\hline 2 & Seddon, Richard & 35 & 8 & 3 & & & 46 & 10 & 4.60 \\
\hline 3 & Fraser, Peter & 40 & 12 & & 2 & & 54 & 12 & 4.50 \\
\hline 4 & Clark, Helen & 10 & 44 & 6 & & & 60 & 14 & 4.29 \\
\hline 5 & Kirk, Norman & 20 & 32 & 3 & & & 55 & 13 & 4.23 \\
\hline 6 & Stafford, Edward & & 8 & & & & 8 & 2 & 4.00 \\
\hline 7 & Lange, David & 20 & 16 & 6 & 4 & & 46 & 12 & 3.83 \\
\hline \multirow[t]{2}{*}{$8=$} & Ballance, John & 5 & 8 & 9 & & & 22 & 6 & 3.67 \\
\hline & Ward, Joseph & & 8 & 3 & & & 11 & 3 & 3.67 \\
\hline \multirow[t]{2}{*}{$10=$} & Holyoake, Keith & 5 & 24 & 12 & 2 & & 43 & 12 & 3.58 \\
\hline & Bolger, Jim & & 20 & 24 & & & 44 & 13 & 3.38 \\
\hline 12 & Coates, Gordon & & 8 & 12 & & & 20 & 6 & 3.33 \\
\hline 13 & Massey, William & 5 & 8 & 9 & 4 & & 26 & 8 & 3.25 \\
\hline 14 & Key, John & 5 & 12 & 24 & 4 & & 45 & 14 & 3.21 \\
\hline 15 & Vogel, Julius & & 8 & 6 & 2 & & 16 & 5 & 3.20 \\
\hline \multirow[t]{2}{*}{$16=$} & Marshall, John & & 4 & 12 & 2 & & 18 & 6 & 3.00 \\
\hline & Nash, Walter & & 16 & 15 & 4 & 1 & 36 & 12 & 3.00 \\
\hline 18 & Grey, George & 5 & 4 & 6 & & 2 & 17 & 6 & 2.83 \\
\hline \multirow[t]{2}{*}{$19=$} & Holland, Sidney & & 4 & 18 & 6 & & 28 & 10 & 2.80 \\
\hline & Stout, Robert & & 4 & 6 & 4 & & 14 & 5 & 2.80 \\
\hline 21 & Atkinson, Harry & & & 9 & 2 & & 11 & 4 & 2.75 \\
\hline 22 & Rowling, Wallace & & 8 & 15 & 6 & 1 & 30 & 11 & 2.73 \\
\hline 23 & English, Bill & & 12 & 15 & 8 & 2 & 37 & 14 & 2.64 \\
\hline 24 & Palmer, Geoffrey & & 12 & 9 & 12 & 1 & 34 & 13 & 2.62 \\
\hline 25 & Fox, William & & & 9 & & 1 & 10 & 4 & 2.50 \\
\hline 26 & Hall, John & & & 3 & 4 & & 7 & 3 & 2.33 \\
\hline 27 & Moore, Mike & & 4 & 9 & 10 & 3 & 26 & 12 & 2.17 \\
\hline 28 & Shipley, Jenny & & 8 & 6 & 8 & 5 & 27 & 13 & 2.08 \\
\hline \multirow[t]{2}{*}{$29=$} & Domett, Alfred & & & 3 & & 1 & 4 & 2 & 2.00 \\
\hline & Forbes, George & & & 6 & 4 & 2 & 12 & 6 & 2.00 \\
\hline 31 & Muldoon, Robert & & 4 & 6 & 8 & 5 & 23 & 12 & 1.92 \\
\hline 32 & Pollen, Daniel & & & 3 & & 2 & 5 & 3 & 1.67 \\
\hline 33 & Weld, Frederick & & & & 2 & 1 & 3 & 2 & 1.50 \\
\hline \multirow[t]{2}{*}{34} & Whitaker, Frederick & & & & & 2 & 2 & 2 & 1.00 \\
\hline & Average & & & & & & & & 3.05 \\
\hline
\end{tabular}

In the survey following the Schlesinger method, results tended to be more or less similar to those in the replication of the 1998 and 2011 studies. Once again, Michael Savage took out the top spot, with Richard Seddon and Peter Fraser ranking in the second and third spots respectively. The top five tends to replicate what is seen in the overall appraisal section of the 2018 study, with Norman Kirk and Helen Clark once again taking out a highly coveted spot. 
However, unlike the 2018 study, Clark manages to take out $4^{\text {th }}$ place, whereas Kirk falls into the $5^{\text {th }}$ place spot.

The Schlesinger replication differs significantly from the 2018 study in terms of the lowest ranked Prime Ministers. Daniel Pollen and George Forbes are once again in the bottom five, although it is Frederick Whittaker who takes out the bottom placing. Mike Moore rises slightly from his rankings in the 2018 study, with a ranking of 27 . However, one of the biggest falls in contrast to the 2018 study is that of Robert Muldoon, who ranks at place number 31 with an overall mean of 1.92. In the 2018 study, Muldoon ranked in the top half of Prime Ministers, coming in at place number 12 in the overall score of mean categories section, and in $17^{\text {th }}$ in the overall appraisal component of the survey.

David Lange ranked higher in this survey than in any other, taking out the $7^{\text {th }}$ place position. When looking at his overall score of categories he instead ranked somewhat lower in the 2018 study, coming in at $11^{\text {th }}$ place. When looking at him in regards to the ranking criteria in the 2018 study, it appears that respondents tended to rank him lower, whereas he tends to bring forth a higher ranking in terms of his overall appraisal.

The Schlesinger replication had seven Prime Ministers that received three or less mentions, one more than that of the other study. However, in contrast to the 2018 study, there were far fewer Prime Ministers mentioned in every response, with only Bill English, John Key and Helen Clark receiving the full number of 14 responses each. 


\section{A new survey: the analysis of generational shifts and recall rates}

As noted, in addition to the replication of the Sheppard and Johansson and Levine rankings, as well as the new study basing itself upon the Schlesinger methods, a third survey method was also designed and carried out. Purposefully designed to look at testing recall rates and the analysis of whether a generational shift was evident amongst results, this survey was administered to students at Victoria University of Wellington. A total of 235 questionnaires were completed across three political science classes and returned to the author. If students felt that they were lacking in knowledge to provide usable answers, they were given the option to refrain from completing the survey. Unlike the other surveys, students were not provided with a list of former New Zealand Prime Ministers. Instead, they were asked to recall to the best of their ability who they believed to be New Zealand's best and worst Prime Ministers, and to give a reason as to why they thought that.

The calculation of results for these surveys was far more straightforward than in the other surveys. Due to students not having to rank each Prime Minister individually, this survey was not calculated as a mean score. Instead, the number of mentions were added up to determine who received the most mentions. Results for both best and worst Prime Ministers have been displayed in the following tables, indicating how many responses were given for each individual across the different classes.

\section{Pols 111: The entry level student perspective}

The first survey was administered to Pols 111, the entry level New Zealand political science class at Victoria University of Wellington. The majority of these students were only in the first few weeks of their Bachelor's degrees at the time of the survey being completed, although a small number of mature students were also in attendance in the class. ${ }^{133}$ The first year New Zealand politics class provided 152 responses overall (in addition to a further three which provided unusable data).

\footnotetext{
${ }^{133}$ It must be taken into consideration when analysing the results that not everyone was aged 18 and in their first year of tertiary study, meaning that some respondents may have had a higher level of knowledge when completing the survey. This could also be the explanation as to why Pols 111 mentioned a higher number of Prime Ministers than Pols 353, despite a potential deeper level of understanding in the 300-level class. This will be addressed further in the limitations section of this thesis.
} 
When looking at the 100-level students' responses for New Zealand's best Prime Minister, Helen Clark dominated this category with 67 responses, quite a large margin over the second-place holder, John Key, with 33 responses. Michael Savage, David Lange and Robert Muldoon rounded out the top five, with 18,11, and 6 responses respectively.

Table 4.4. Pols 111: Best and Worst Prime Ministers (March 2018)

\begin{tabular}{|c|c|c|}
\hline Prime Minister & Best & Worst \\
\hline \multicolumn{3}{|l|}{ Atkinson, Harry } \\
\hline Ballance, John & 2 & \\
\hline Bolger, Jim & & 2 \\
\hline Clark, Helen & 67 & 10 \\
\hline \multicolumn{3}{|l|}{ Coates, Gordon } \\
\hline \multicolumn{3}{|l|}{ Domett, Alfred } \\
\hline English, Bill & 3 & 12 \\
\hline Forbes, George & & 1 \\
\hline Fox, William & & 4 \\
\hline \multicolumn{3}{|l|}{ Fraser, Peter } \\
\hline Grey, George & & 2 \\
\hline \multicolumn{3}{|l|}{ Hall, John } \\
\hline \multicolumn{3}{|l|}{ Holland, Sidney } \\
\hline Holyoake, Keith & 1 & 2 \\
\hline Key, John & 33 & 24 \\
\hline Kirk, Norman & 3 & \\
\hline Lange, David & 11 & 2 \\
\hline \multicolumn{3}{|l|}{ Marshall, John } \\
\hline Massey, William & & 1 \\
\hline Moore, Mike & 1 & \\
\hline Muldoon, Robert & 6 & 74 \\
\hline \multicolumn{3}{|l|}{ Nash, Walter } \\
\hline Palmer, Geoffrey & 4 & 3 \\
\hline \multicolumn{3}{|l|}{ Pollen, Daniel } \\
\hline \multicolumn{3}{|l|}{ Rowling, Wallace } \\
\hline Savage, Michael & 18 & \\
\hline Seddon, Richard & 4 & 1 \\
\hline Shipley, Jenny & & 7 \\
\hline \multicolumn{3}{|l|}{ Stafford, Edward } \\
\hline \multicolumn{3}{|l|}{ Stout, Robert } \\
\hline \multicolumn{3}{|l|}{ Vogel, Julius } \\
\hline \multicolumn{3}{|l|}{ Ward, Joseph } \\
\hline Weld, Frederick & & \\
\hline Whitaker, Frederi & & \\
\hline
\end{tabular}

Robert Muldoon was clearly the worst ranked Prime Minister, with 74 responses. John Key once again took the second-place position, following significantly behind Muldoon with 24 responses. The bottom five was finished with Bill English, Helen Clark and Jenny Shipley, with each Prime Minister bringing forth relatively few responses in comparison to Muldoon. 
A total of 18 Prime Ministers were mentioned. Mentions tended to gravitate towards more recent Prime Ministers as opposed to those who served in office in earlier years, which could indicate to some extent the impact of the recency effect.

\section{Pols 353: The final year Bachelor's student perspective}

Table 4.5. Pols 353: Best and Worst Prime Ministers (March 2018)

\begin{tabular}{|c|c|c|}
\hline Prime Minister & Best & Worst \\
\hline \multicolumn{3}{|l|}{ Atkinson, Harry } \\
\hline \multicolumn{3}{|l|}{ Ballance, John } \\
\hline Bolger, Jim & 1 & \\
\hline Clark, Helen & 13 & 3 \\
\hline \multicolumn{3}{|l|}{ Coates, Gordon } \\
\hline \multicolumn{3}{|l|}{ Domett, Alfred } \\
\hline English, Bill & 1 & 2 \\
\hline Forbes, George & & 1 \\
\hline Fox, William & & 1 \\
\hline Fraser, Peter & 2 & \\
\hline \multicolumn{3}{|l|}{ Grey, George } \\
\hline \multicolumn{3}{|l|}{ Hall, John } \\
\hline \multicolumn{3}{|l|}{ Holland, Sidney } \\
\hline \multicolumn{3}{|l|}{ Holyoake, Keith } \\
\hline Key, John & 2 & 4 \\
\hline \multicolumn{3}{|l|}{ Kirk, Norman } \\
\hline Lange, David & 6 & 1 \\
\hline \multicolumn{3}{|l|}{ Marshall, John } \\
\hline Massey, William & & 1 \\
\hline \multicolumn{3}{|l|}{ Moore, Mike } \\
\hline Muldoon, Robert & 1 & 19 \\
\hline Nash, Walter & & 3 \\
\hline Palmer, Geoffrey & 2 & \\
\hline \multicolumn{3}{|l|}{ Pollen, Daniel } \\
\hline \multicolumn{3}{|l|}{ Rowling, Wallace } \\
\hline Savage, Michael & 7 & \\
\hline Seddon, Richard & 4 & \\
\hline Shipley, Jenny & & 4 \\
\hline \multicolumn{3}{|l|}{ Stafford, Edward } \\
\hline \multicolumn{3}{|l|}{ Stout, Robert } \\
\hline \multicolumn{3}{|l|}{ Vogel, Julius } \\
\hline \multicolumn{3}{|l|}{ Ward, Joseph } \\
\hline Weld, Frederick & & \\
\hline Whitaker, Frederi & & \\
\hline
\end{tabular}

Despite possible further knowledge and a more comprehensive understanding of former Prime Ministers, the 300-level class produced near-identical results in the form of Helen Clark being rated as the best Prime Minister and Robert Muldoon the worst. Helen Clark once again led the best Prime Minister category, although with a slightly smaller margin than in the Pols 111 results. In total, she gained 13 responses in favour of her being the best Prime Minister. 
Following Clark and rounding out the top four was Michael Savage, David Lange and Richard Seddon with 7, 6 and 4 responses respectively. The fifth-place position was taken equally by Peter Fraser, John Key and Geoffrey Palmer, each gaining two mentions from students.

Once again, Robert Muldoon topped the worst Prime Minister category, with 19 mentions overall. John Key and Jenny Shipley fell into the second-place position, with four mentions each - a rather significant difference between that and the mentions that Muldoon received. Helen Clark and Walter Nash took the third-place position, with three ratings each.

In this sample, a total of 15 Prime Ministers were rated. ${ }^{134}$ Once again, ratings tended to favour the more recent prime ministers as opposed to those earlier serving individuals, although this sample tended to include some Prime Ministers not mentioned in the Pols 111 results. ${ }^{135}$

In conjunction with undertaking the survey in March 2018, the 300-level political science class also completed the survey again in June 2018 following the completion of the course, in order to further investigate whether time was a factor in producing different results. Whilst the March survey had a total of 39 completed responses, the exercise undertaken in June was slightly smaller, with a total of 24 completed surveys. Despite the smaller sample size, results were relatively similar to those seen in the data that had been collected in March 2018 . Once again, Helen Clark took out the top spot as the 'best' prime minister, although by a far smaller margin, with seven responses compared to her original 13. David Lange follows close behind in second place, with five responses, one less than his original rating given by the class in the first exercise. Small differences in results occurred further down the rankings, with Michael Savage moving from second place in the earlier exercise with seven responses, to the lowest ranked 'best' position, with only one response. Keith Holyoake, John Hall and Mike Moore gained 'best' rankings, with no mentions in the first exercise compared to receiving mentions in the June rankings. Likewise, the best rankings that were received by Jim Bolger, Bill English and Robert Muldoon were not replicated in the second exercise, with each Prime Minister receiving no best mentions in the June rankings.

\footnotetext{
${ }^{134}$ Compared to Pols 111, the Pols 353 class had a smaller number of former Prime Ministers mentioned. This could be due to Pols 111 having a far larger sample size, resulting in more Prime Ministers being mentioned overall.

${ }^{135}$ Peter Fraser and Walter Nash received no mentions in the Pols 111 survey although they were included in the Pols 353 results, with 5 mentions between them.
} 
Table 4.6. Pols 353: Best and Worst Prime Ministers (June 2018)

\begin{tabular}{|c|c|c|}
\hline Prime Minister & Best & Worst \\
\hline \multicolumn{3}{|l|}{ Atkinson, Harry } \\
\hline \multicolumn{3}{|l|}{ Ballance, John } \\
\hline Bolger, Jim & & 2 \\
\hline Clark, Helen & 7 & \\
\hline \multicolumn{3}{|l|}{ Coates, Gordon } \\
\hline \multicolumn{3}{|l|}{ Domett, Alfred } \\
\hline \multicolumn{3}{|l|}{ English, Bill } \\
\hline Forbes, George & & 1 \\
\hline \multicolumn{3}{|l|}{ Fox, William } \\
\hline Fraser, Peter & 2 & \\
\hline Grey, George & & 1 \\
\hline Hall, John & 1 & \\
\hline \multicolumn{3}{|l|}{ Holland, Sidney } \\
\hline Holyoake, Keith & 1 & \\
\hline Key, John & 1 & 2 \\
\hline \multicolumn{3}{|l|}{ Kirk, Norman } \\
\hline Lange, David & 5 & 2 \\
\hline \multicolumn{3}{|l|}{ Marshall, John } \\
\hline \multicolumn{3}{|l|}{ Massey, William } \\
\hline Moore, Mike & 2 & \\
\hline Muldoon, Robert & & 12 \\
\hline Nash, Walter & & 1 \\
\hline Palmer, Geoffrey & 1 & \\
\hline \multicolumn{3}{|l|}{ Pollen, Daniel } \\
\hline \multicolumn{3}{|l|}{ Rowling, Wallace } \\
\hline Savage, Mich ael & 1 & \\
\hline Seddon, Richard & 2 & 1 \\
\hline Shipley, Jenny & & 2 \\
\hline \multicolumn{3}{|l|}{ Stafford, Edward } \\
\hline \multicolumn{3}{|l|}{ Stout, Robert } \\
\hline \multicolumn{3}{|l|}{ Vogel, Julius } \\
\hline \multicolumn{3}{|l|}{ Ward, Joseph } \\
\hline Weld, Frederick & & \\
\hline Whitaker, Frederick & & \\
\hline
\end{tabular}

When looking at the rankings that determined the 'worst' prime minister, results once again remained very similar to the exercise that was undertaken by the class in March. Robert Muldoon took out the top spot again, with 12 'worst' responses. All other Prime Ministers that received 'worst' mentions only gained either one or two responses, with no one coming close to Muldoon's score. However, in contrast to the first exercise completed by the 300 -level class, multiple Prime Ministers either gained or lost their 'worst' rankings in the June survey. Jim Bolger, George Grey and Richard Seddon each received one 'worst' ranking, compared to none in the earlier exercise. Helen Clark, William Fox, Bill English and William Massey all lost their 'worst' rankings in the June exercise, resulting in Fox, English and Massey not being mentioned in the second survey whatsoever. In this exercise, a total of 16 Prime Ministers were rated, one more than in the previous survey that was conducted with the 300-level class. 
Furthermore, this survey included rankings for four Prime Ministers not mentioned in the March exercise (Grey, Hall, Holyoake and Moore) and excluded three mentioned in the original survey (English, Fox and Massey).

\section{Pols 428: The postgraduate perspective}

The third and final sample of this survey was administered to Pols 428, the parliamentary internship class at Victoria University of Wellington.

Each student has inner workings of knowledge towards the New Zealand parliamentary system, as they are each undertaking a year-long internship with a current sitting MP in a party of their choice. Furthermore, each student in this class has completed some form of Bachelor's degree and is enrolled in postgraduate study to further their education in Political Science, International Relations or Strategic Studies.

A total of nine students were surveyed. This was also the only class where every student present completed a survey. In addition, this was also the only class where electronic devices (cell phones, laptops etc.) were not used when completing the survey, meaning that responses were not influenced by this in any way, and were rather based on the student's existing knowledge instead. ${ }^{136}$

Unlike the undergraduate classes that were surveyed, Pols 428 delivered a far more spread out rating of individuals, particularly when assessing who they believed to be the best Prime Minister. Whilst Helen Clark dominated the responses in both Pols 111 and Pols 353, she only received one 'best' rating in this class. Michael Savage received three ratings as the best Prime Minister, followed by David Lange with two mentions. Norman Kirk, John Key, and Richard Seddon received one mention each, rounding out the nine mentions in total.

\footnotetext{
${ }^{136}$ Due to the large samples of Pols 111 and Pols 353, the researcher had no control as to whether electronic devices were used to aid responses for those who had limited knowledge. This aspect of surveying will be further addressed in Chapter Six of this thesis.
} 
Table 4.7. Pols 428: Best and Worst Prime Ministers (March 2018)

\begin{tabular}{|c|c|c|}
\hline Prime Minister & Best & Worst \\
\hline \multicolumn{3}{|l|}{ Atkinson, Harry } \\
\hline \multicolumn{3}{|l|}{ Ballance, John } \\
\hline Bolger, Jim & & 1 \\
\hline Clark, Helen & 1 & \\
\hline \multicolumn{3}{|l|}{ Coates, Gordon } \\
\hline \multicolumn{3}{|l|}{ Domett, Alfred } \\
\hline \multicolumn{3}{|l|}{ English, Bill } \\
\hline \multicolumn{3}{|l|}{ Forbes, George } \\
\hline \multicolumn{3}{|l|}{ Fox, William } \\
\hline \multicolumn{3}{|l|}{ Fraser, Peter } \\
\hline \multicolumn{3}{|l|}{ Grey, George } \\
\hline \multicolumn{3}{|l|}{ Hall, John } \\
\hline \multicolumn{3}{|l|}{ Holland, Sidney } \\
\hline \multicolumn{3}{|l|}{ Holyoake, Keith } \\
\hline Key, John & 1 & 1 \\
\hline Kirk, Norman & 1 & \\
\hline Lange, David & 2 & \\
\hline \multicolumn{3}{|l|}{ Marshall, John } \\
\hline \multicolumn{3}{|l|}{ Massey, William } \\
\hline \multicolumn{3}{|l|}{ Moore, Mike } \\
\hline Muldoon, Robert & & 7 \\
\hline \multicolumn{3}{|l|}{ Nash, Walter } \\
\hline \multicolumn{3}{|l|}{ Palmer, Geoffrey } \\
\hline \multicolumn{3}{|l|}{ Pollen, Daniel } \\
\hline \multicolumn{3}{|l|}{ Rowling, Wallace } \\
\hline Savage, Michael & 3 & \\
\hline Seddon, Richard & 1 & \\
\hline \multicolumn{3}{|l|}{ Shipley, Jenny } \\
\hline \multicolumn{3}{|l|}{ Stafford, Edward } \\
\hline \multicolumn{3}{|l|}{ Stout, Robert } \\
\hline \multicolumn{3}{|l|}{ Vogel, Julius } \\
\hline \multicolumn{3}{|l|}{ Ward, Joseph } \\
\hline Weld, Frederick & & \\
\hline Whitaker, Frederi & & \\
\hline
\end{tabular}

In terms of the worst Prime Minister, Pols 428 followed in the footsteps of the undergraduate classes in clearly believing that Robert Muldoon was the worst Prime Minister that New Zealand has had. Overall, he received seven mentions in this category, by far the largest majority of the entire survey. Rounding out the nine responses were John Key and Jim Bolger with one mention each.

In total, eight Prime Ministers were mentioned in the survey completed by the students of Pols 428. However, unlike the undergraduate classes, this class tended to value Michael Joseph Savage more so than the more recent Prime Ministers. 


\section{Chapter Five: Discussion}

\section{Replication of multi question methods}

N.B. Following on from the previous analysis by the authors of the 1998 and the 2011 exercises, this discussion predominately refers to the overall rankings of performance categories unless stated otherwise. When observing the results of the survey following the Schlesinger methodology, this discussion contrasts them with the results of the overall appraisal component of the 2018 survey, due to being the most similar results to compare.

Contrast with 1998 and 2011 results

In the 1998 study, Sheppard noted that the results of the exercise were flexible and provided an accurate reflection of general consensus at the time. ${ }^{137}$ The introduction of ranking studies in New Zealand has allowed for the tracking of fluctuating perceptions and revised interpretations of former leaders (and the parties and policies that they were associated with). ${ }^{138}$ The completion of the 2011 exercise illustrated a similar point, with the authors anticipating that the survey instrument would 'be sensitive to shifting historical judgements on primeministerial leadership as contexts change and reassessments are made.'139

On the whole, the results of the 2018 exercise capture the former trends that were witnessed in both the 1998 and 2011 studies. Three distinctive factors are correlated with being considered a 'great' Prime Minister: longevity, death in office, and 'big change' or crisis leadership.

Johansson and Levine noted in their exercise that respondents deemed longevity as one of the defining factors of an excellent prime minister, with the exercise showing nearly all longserving prime ministers in the top ten. ${ }^{140}$ Likewise, Sheppard also noted the influence of

\footnotetext{
${ }^{137}$ See Simon Sheppard. 'Ranking New Zealand's Prime Ministers.' p. 89.

138 Ibid.

${ }^{139}$ See Johansson and Levine. 'Evaluating Prime Ministerial Performance: The New Zealand Experience.' p. 310 .

${ }^{140}$ Johansson and Levine defined long-serving Prime Ministers as those who had served longer than nine years or won at least three general elections. The 2011 results saw these prime ministers dominate in the top tier, with Seddon, Fraser, Massey, Holyoake, Bolger and Clark each placing in the top tier. Muldoon was the only exception, placing just outside the top ten in $11^{\text {th }}$ place. See Jon Johansson and Stephen Levine. 'Evaluating Prime Ministerial Performance: The New Zealand Experience.' p. 312.
} 
longevity as a ranking guide, with all five of the long-serving Prime Ministers at the time appearing in the top ten. ${ }^{141}$

Table 5.1. Comparison of 1998, 2011 and 2018 results by overall appraisal of performance

\begin{tabular}{|c|c|c|c|}
\hline \multirow{2}{*}{ Prime Minister } & 1998 & 2011 & 2018 \\
\hline & Rank & Rank & Rank \\
\hline Atkinson, Harry & 11 & 21 & 20 \\
\hline Ballance, John & 5 & 7 & $9=$ \\
\hline Bolger, Jim & 12 & 10 & 15 \\
\hline Clark, Helen & - & 4 & 5 \\
\hline Coates, Gordon & $14=$ & 12 & 18 \\
\hline Domett, Alfred & $28=$ & 31 & $23=$ \\
\hline English, Bill & - & - & 22 \\
\hline Forbes, George & 30 & 32 & 34 \\
\hline Fox, William & 27 & 28 & 32 \\
\hline Fraser, Peter & 2 & 1 & $1=$ \\
\hline Grey, George & 21 & 25 & $23=$ \\
\hline Hall, John & 18 & $16=$ & $23=$ \\
\hline Holland, Sidney & 16 & 11 & 16 \\
\hline Holyoake, Keith & 6 & 5 & $7=$ \\
\hline Key, John & - & - & 13 \\
\hline Kirk, Norman & 3 & 6 & 4 \\
\hline Lange, David & 13 & 14 & $9=$ \\
\hline Marshall, John & 23 & 22 & 27 \\
\hline Massey, William & 8 & 8 & $7=$ \\
\hline Moore, Mike & 24 & 27 & $30=$ \\
\hline Muldoon, Robert & 9 & $16=$ & 17 \\
\hline Nash, Walter & $14=$ & $18=$ & 21 \\
\hline Palmer, Geoffrey & 22 & 15 & 26 \\
\hline Pollen, Daniel & $28=$ & 30 & 33 \\
\hline Rowling, Wallace & 19 & 23 & 28 \\
\hline Savage, Michael & 4 & 3 & $1=$ \\
\hline Seddon, Richard & 1 & 2 & 3 \\
\hline Shipley, Jenny & - & 26 & $30=$ \\
\hline Stafford, Edward & 10 & 13 & $9=$ \\
\hline Stout, Robert & 20 & 20 & $9=$ \\
\hline Vogel, Julius & 7 & 9 & 6 \\
\hline Ward, Joseph & 17 & $18=$ & 14 \\
\hline Weld, Frederick & 25 & 24 & 19 \\
\hline Whitaker, Frederick & 26 & 29 & 29 \\
\hline
\end{tabular}

In the 2018 survey, longevity again influenced results. Most long-serving Prime Ministers were staggered throughout the top tier, with Clark, Fraser, Holyoake, Massey and Seddon all ranking within the top ten. Muldoon and Bolger proved to be the only exceptions

\footnotetext{
${ }^{141}$ Sheppard defined long-serving Prime Ministers as those who had served 'nine or more years - or the equivalent of three full consecutive terms in office.' Those Prime Ministers included as long-serving Prime Ministers were Seddon, Massey, Stafford, Holyoake and Fraser, who all ranked in the top 10 of the 1998 study. See Simon Sheppard. 'Ranking New Zealand's Prime Ministers.' p. 82.
} 
amongst such a trend, ranking in $12^{\text {th }}$ and $15^{\text {th }}=$ respectively. ${ }^{142}$ Multiple respondents noted in their the influence of longevity on the rankings of Prime Ministers such as Fraser and Seddon, with one noting that Fraser 'benefitted from his long tenure (9 years) and the legislative achievements of his predecessor, when he effectively acted as deputy.' Some respondents also refused to rank certain Prime Ministers due to longevity, arguing that the only way to best assess performance was based on how many times a Prime Minister had been re-elected.

The second link that the 2018 survey results provide toward Prime Ministerial greatness appears to be more of a speculative one, observing the perceptions of 'what could have been'. As noted in the 2011 results, the sympathetic notion of New Zealanders appears prevalent in the rankings of Prime Ministers, with prematurely terminated leadership (through death in office) being indicated as a link to elevated reputation in the exercise. ${ }^{143}$ The death of a prominent figure in New Zealand can bring forth large public displays of grief and sorrow and has done so prominently with political figureheads in the past. The sudden death of Savage in 1940 elicited an unprecedented response from thousands. ${ }^{144}$ An estimated 200,000 people were said to have lined along Queen Street in Auckland, as Savage made his way to his temporary resting place at Fort Bastion as a 'last gesture of respect and affection.' 145 In addition, an enormous tribute took place along 20 stops on a 720 kilometre route on Savage's final journey from Wellington to Auckland, and 50,000 people were estimated to have filed past the body as it lay in state in the vestibule of Parliament. ${ }^{146}$ Similar displays of public mourning and gratitude took place when Kirk passed away in 1974, with Jim Anderton noting that such an outpouring of public grief had not been seen since Savage's passing. ${ }^{147}$ The prospect of 'what could have been' is prominent in the 2011 survey results, with all five Prime Ministers who died in office placing in the top ten positions (Seddon $1^{\text {st }}$, Savage $3^{\text {rd }}$, Kirk $7^{\text {th }}$, Ballance $8^{\text {th }}$ and

\footnotetext{
${ }^{142}$ The 2011 survey excluded Sidney Holland as being deemed a long-serving Prime Minister due to the fact that he never completed his third term and resigned early from office. Likewise, for the 2018 study John Key has also been excluded from this category, due to also not completing his third term in office.

${ }^{143}$ See Jon Johansson and Stephen Levine. 'Evaluating Prime Ministerial Performance: The New Zealand Experience.' p. 312.

${ }^{144}$ See Barry Gustafson. 1986. From the Cradle to the Grave: A Biography of Michael Joseph Savage. Auckland: Reed Methuen. p. 271.

${ }^{145}$ Savage's body remained in the Fort Bastion burial vault until June 1941, where he was removed for a further two years to St Patricks Cathedral until the Savage Memorial was completed in 1943. He was laid to rest for the final time before a crowd of 10,000 people on 28 March 1943. See Barry Gustafson. From the Cradle to the Grave: A Biography of Michael Joseph Savage. p. 271.

146 Ibid.

${ }^{147}$ See Jim Anderton. 2001. 'Kirk and Rowling: Recollections and Significance.' In Margaret Clark (ed). Three Labour Leaders. 50-58. Palmerston North: Dunmore. p. 51.
} 
Massey $\left.9^{\text {th }}\right) .{ }^{148}$ Likewise, the trend is replicated in the results of the 2018 survey, with all five Prime Ministers appearing once again, indicating the attitudes of New Zealanders following the death of a public figure, and the feeling of uncertainty when observing what the future could have held should these political leaders not have died in office. Whilst the trend was never analysed by Sheppard in the initial 1998 survey, Kirk's premature passing was mentioned in another aspect of the exercise, with one respondent noting him as the best Prime Minister New Zealand never had, writing 'I would say Norman Kirk, not because he wasn't but because he was cut so short. If he had lived New Zealand would be a very different place.' 149

Like the initial surveys, the last factor that provides a connection to Prime Ministerial greatness is the idea of 'big change' or crisis leadership. In his book The Politics of Possibility: Leadership in Changing Times, Jon Johansson argues that a big change period is a "political transformation that has fundamentally changed the direction of, and produced a defining impact on, the conduct of our politics.' ${ }^{150}$ Since the signing of the Te Tiriti o Waitangi in 1840, there have been four big-change moments that have had a defining impact on domestic politics, each attributed to the performance of specific Prime Ministers. ${ }^{151}$ The 2011 survey analysed the positioning of those deemed 'big change' or crisis Prime Ministers, with the authors considering eight of the assessed leaders as falling into this category. ${ }^{152}$ Of these eight figures, seven were included in the top ten positions, allowing a link to be formed between being considered a big change or crisis Prime Minister, and having an elevated reputation in performance rankings. The 2018 survey again shows the same trend. Of the Prime Ministers that can be considered in this category, six of them are ranked by respondents in the top ten (Savage $1^{\text {st }}$, Seddon $3^{\text {rd }}$, Fraser $5^{\text {th }}$, Massey $6^{\text {th }}$, Vogel $8^{\text {th }}$ and Ballance $10^{\text {th }}$.)

\footnotetext{
${ }^{148}$ See Jon Johansson and Stephen Levine. 'Evaluating Prime Ministerial Performance: The New Zealand Experience.' p. 312.

${ }_{149}$ See Simon Sheppard. 'Ranking New Zealand's Prime Ministers.' p. 88.

${ }^{150}$ See Jon Johansson. 2009. The Politics of Possibility: Leadership in Changing Times. Wellington: Dunmore. p. 55.

${ }^{151}$ Johansson lists the four big change periods as Vogel and the centralisation of New Zealand politics, Seddon's enduring administration and their response to post-Vogel expansionism, Savage and Fraser's First Labour Government, and Lange's Fourth Labour Government. See Jon Johansson. The Politics of Possibility: Leadership in Changing Times. p. 55, 58, 62 and 70.

${ }^{152}$ The authors of the 2011 survey determined that Vogel, Ballance, Seddon, Massey, Savage, Fraser, Lange and Bolger were those considered 'big change' or crisis Prime Ministers. See Jon Johansson and Stephen Levine.

'Evaluating Prime Ministerial Performance: The New Zealand Experience.' p. 312.
} 
Table 5.2. Comparison of 1998, 2011 and 2018 results by overall mean score of performance categories

\begin{tabular}{lcccccc}
\hline Prime Minister & 1998 Mean & 1998 & 2011 Mean & 2011 & 2018 Mean & 2018 \\
& Score & Rank & Score & Rank & Score & Rank \\
\hline Atkinson, Harry & 30.37 & 13 & 27.10 & 22 & 28.58 & 25 \\
Ballance, John & 35.86 & 4 & 35.55 & 8 & 36.85 & 10 \\
Bolger, Jim & 29.93 & 15 & 36.98 & 5 & 33.50 & $15=$ \\
Clark, Helen & - & - & 37.44 & 4 & 39.29 & 2 \\
Coates, Gordon & 27.75 & 17 & 29.85 & 16 & 29.15 & 22 \\
Domett, Alfred & 15.99 & 30 & 18.64 & 31 & 28.00 & $27=$ \\
English, Bill & - & - & - & - & 30.57 & $19=$ \\
Forbes, George & 18.39 & 29 & 18.32 & 32 & 21.30 & 34 \\
Fox, William & 23.01 & 26 & 24.96 & 26 & 22.75 & 33 \\
Fraser, Peter & 38.61 & 2 & 40.69 & 2 & 38.99 & 5 \\
Grey, George & 27.11 & 18 & 27.67 & 20 & 27.08 & 30 \\
Hall, John & 23.08 & 25 & 27.27 & 21 & 27.80 & 29 \\
Holland, Sidney & 30.48 & 12 & 33.47 & 12 & 34.25 & 14 \\
Holyoake, Keith & 35.34 & 5 & 36.95 & 6 & 39.04 & 4 \\
Key, John & - & - & - & - & 36.86 & 9 \\
Kirk, Norman & 35.07 & 6 & 36.95 & 7 & 37.38 & 7 \\
Lange, David & 31.06 & 11 & 31.68 & 13 & 35.79 & 11 \\
Marshall, John & 24.08 & 21 & 28.24 & 19 & 30.57 & $19=$ \\
Massey, William & 33.84 & 7 & 35.54 & 9 & 37.50 & 6 \\
Moore, Mike & 20.65 & 28 & 24.81 & 27 & 25.86 & 31 \\
Muldoon, Robert & 32.88 & 9 & 34.99 & 11 & 34.71 & 12 \\
Nash, Walter & 29.92 & 16 & 31.51 & 14 & 31.58 & 18 \\
Palmer, Geoffrey & 23.83 & 23 & 26.36 & 24 & 30.08 & 21 \\
Pollen, Daniel & 24.00 & 22 & 18.68 & 30 & 23.00 & 32 \\
Rowling, Wallace & 24.80 & 20 & 28.27 & 18 & 29.09 & 23 \\
Savage, Michael & 36.63 & 3 & 38.48 & 3 & 42.07 & 1 \\
Seddon, Richard & 41.71 & 1 & 41.37 & 1 & 39.09 & 3 \\
Shipley, Jenny & - & - & 25.99 & 25 & 28.14 & 26 \\
Stafford, Edward & 31.48 & 10 & 31.19 & 15 & 34.50 & 13 \\
Stout, Robert & 26.80 & 19 & 26.67 & 23 & 33.50 & $15=$ \\
Vogel, Julius & 33.28 & 8 & 35.02 & 10 & 37.20 & 8 \\
Ward, Joseph & 30.31 & 14 & 29.60 & 17 & 32.50 & 17 \\
Weld, Frederick & 21.62 & 27 & 24.40 & 28 & 28.83 & 24 \\
Whitaker, Frederick & 23.69 & 24 & 21.75 & 29 & 28.00 & $27=$ \\
\hline & & & & & &
\end{tabular}

It was argued in 2011 that William Massey provided a curious perspective on such a link to Prime Ministerial greatness. Whilst he led for thirteen years, including during the Great War, and subsequently died in office, the authors noted that Massey never managed to attract the same level of respect that Seddon or Fraser did, nor did he encapsulate Savage's emotional legacy. ${ }^{153}$ The 2018 results contradict this analysis. Massey rises three places to $6^{\text {th }}$ place overall, and subsequently gained the highest score of all Prime Ministers in regard to his parliamentary skills, with a ranking of 9.20. His placing between Fraser and Kirk shows the increase in awareness of the legacy of Massey, and the consolidation and elevation of his

\footnotetext{
${ }^{153}$ See Jon Johansson and Stephen Levine. 'Evaluating Prime Ministerial Performance: The New Zealand Experience.' p. 313.
} 
leadership in a time of crisis. Whilst Massey still struggles to attract the same level of respect as Seddon, his edging closer to Fraser in the rankings indicates a shift in the public perception of his leadership, something that may develop further as knowledge is interpreted over time. Additionally, the heightening of Massey's legacy can further reflect a rise in the interest in World War I, which has become especially prominent amongst New Zealanders following the commencement of its centenary in 2014.

David Lange, responsible for New Zealand's fourth transformational period, rises two places from the 2011 results. He rises from $13^{\text {th }}$ to $11^{\text {th }}$ place in the results of the 2018 survey (returning to his original ranking seen in the 1997 results). In 2011, it was argued by the authors that Lange's fall to $13^{\text {th }}$ place reflected the 'reality that the Prime Minister who led during New Zealand's most recent transformational cycle of politics was not regarded by respondents as effectively in charge.' ${ }^{154}$ The 2018 results contradict such a statement, with the current public perception of Lange's performance being heightened, regardless of him placing outside of the top ten. Such an elevation plays on the current domestic political context, with Lange's left leaning principles and ideas being prevalent in politics currently.

The results of the 2018 survey, when compared with its predecessors, shows very little fluctuation. The heightened rankings of Labour stalwarts Savage and Clark may reflect the attitude of the nation at the present time, creating a snapshot of a general consensus similar to what is being seen in current domestic politics. In some cases, there is a slight movement of rankings, with perceptions of Prime Ministers such as Holyoake and Lange continuing to rise. Bolger takes a big fall, moving from $5^{\text {th }}$ position in the 2011 study to $15^{\text {th }}=$ in the current rankings. However, such a fall may be a result of left-wing bias amongst participants, or simply Bolger's time in office being pushed aside to favour Clark and Key. Fraser also takes a significant fall - not in size, but rather in the fact that he drops out of the top three positions. However, Fraser's performance and legacy is still recognised highly by respondents, as he still manages to retain a place in the top five, and in the top three by overall appraisal. Despite slight shifts, the rankings remain relatively similar for the most part, and continue to show and track the perceptions of the New Zealand public towards Prime Ministerial leadership.

\section{The top three}

\footnotetext{
${ }^{154}$ See Jon Johansson and Stephen Levine. 'Evaluating Prime Ministerial Performance: The New Zealand Experience.' p. 313.
} 
To define those who embody the criteria of outstanding political leadership may appear difficult at first glance, but the results of the survey say otherwise. The 2018 survey sees Savage, Clark and Seddon in the top three positions, reflecting on their perceived high standard of leadership and exceptional overall performance in office. The three Prime Ministers raise the bar high for future successors and embody the New Zealand political system at its finest.

Throughout the surveys that have been undertaken in the past, Michael Joseph Savage has been consistent in retaining a top three position - indicating an exceptional level of performance and significant public appreciation and respect. The results of the 2018 survey see his ranking rise to the top position. Savage began his term in office in 1935 and went on to lead through one of the most transformational and crucial periods in New Zealand's domestic politics. Defined as being 'charismatic before the term was even invented', Savage has since been regarded as being like no other Prime Minister in New Zealand's history. ${ }^{155}$

Table 5.3. Comparison of Savage Rankings 1998/2011/2018

\begin{tabular}{lccc}
\hline & $\begin{array}{c}\text { Sheppard } \\
(1998)\end{array}$ & $\begin{array}{c}\text { Johansson and } \\
\text { Levine (2011) }\end{array}$ & 2018 \\
\hline Overall Ranking (by & 3 & 3 & 1 \\
categories) & 2 & 4 & 1 \\
Leadership Qualities & 10 & 10 & 4 \\
Parliamentary Skills & 7 & 6 & 4 \\
Party Management & 8 & 5 & 1 \\
Crisis Management & 2 & 2 & 2 \\
Legislative Achievements & & 3 & 1 \\
Overall Appraisal & 4 & &
\end{tabular}

In conjunction with shaping the future of social welfare for generations to come, Savage embodied many of the components of successful political leadership. He had a special relationship with many New Zealanders - something that many Prime Ministers have failed to achieve. As noted by Keith Sinclair, Savage was '... a benign political uncle, cosy, a good mixer, with a warmly emotional appeal.' 156 Savage's revolutionary social welfare policy helped to show his empathy and compassion for all New Zealanders. His decisiveness and intelligence - especially whilst responding to the society-wide crisis of the Great Depression,

\footnotetext{
155 See Ian Grant. Public Lives: New Zealand's Premiers and Prime Ministers 1856-2003. p. 108.

${ }^{156}$ See Keith Sinclair. 1959. A History of New Zealand. $5^{\text {th }}$ Ed. Auckland: Penguin. p. 275.
} 
and subsequently leading the nation into World War II - is said to have given him 'a special place in New Zealanders memories. ${ }^{157}$

Overwhelmingly, the public support for Savage appears evident in the 2018 survey. Ranking no lower than $4^{\text {th }}$ place in any of the performance categories and taking out the number one place in both the overall appraisal and the overall ranking reinforces the idea that the political and academic elite reflect highly on his performance in office, to which no other Prime Minister can compare. Savage is regarded highest by respondents for his leadership qualities and crisis management where he led the country with ease and professionalism, and subsequently retains his second-place position for legislative achievements - namely as a result of his ground-breaking welfare policies. One response noted the following.

'Without contest, the highest ranked Prime Minister would be Michael Savage. His policies have managed to frame the national debate in regards to the role of the state, more so than any other Prime Minister.'

The placement of Savage in the top position proves significant, particularly due to his short time in office. With the top position being previously held by Seddon - who served for over a decade - Savage's four-year stint pales in comparison. In some senses, Savage's high ranking may be a result of respondents wondering what could have been and showing great respect for his legacy. However, Savage's compassion, empathy and relationship with the nation propel him deservedly into the top position.

The authors of the 2011 study raised the question of whether Helen Clark's high standing would be maintained, or whether the Global Financial crisis coinciding with the change of government in 2008 would act against Clark's legacy - similarly to the public perception of the Holyoake years with the economic shocks of the 1970's and 1980's. ${ }^{158}$ Clark not only manages to maintain her high standing but advances even further to second place.

As the second female Prime Minister in New Zealand, Clark made her mark on domestic politics in her nine years in office through her formidable character. Clark was

\footnotetext{
${ }^{157}$ See Jon Johansson and Stephen Levine. 'Evaluating Prime Ministerial Performance: The New Zealand Experience.' p. 306.

${ }^{158}$ Ibid., p. 309.
} 
succinct, strategic and intelligent, and had a hand on all her political matters. Clark was said to have learned from the mistakes of the fourth Labour Government and was focused on maintaining cabinet unity within her party - which was demonstrated particularly through her relationship with her Minister of Finance, Michael Cullen. ${ }^{159}$ Clark sought to regain legitimacy and the trust of the public through a 'rock-solid platform', argued to have been a contributing factor towards her longevity in office. ${ }^{160}$ Her political stability and changing the game for female representation were regarded as pivotal moments in New Zealand by survey respondents.

Table 5.4. Comparison of Clark Rankings 2011/2018

\begin{tabular}{lccc}
\hline & $\begin{array}{c}\text { Sheppard } \\
(1998)\end{array}$ & $\begin{array}{c}\text { Johansson } \\
\text { and Levine } \\
(2011)\end{array}$ & 2018 \\
\hline Overall Ranking (by & - & 4 & 2 \\
categories) & - & 5 & 6 \\
Leadership Qualities & - & 9 & 6 \\
Parliamentary Skills & - & 2 & 1 \\
Party Management & - & 4 & 7 \\
Crisis Management & - & 7 & 11 \\
Legislative Achievements & - & 4 & 5 \\
& - & & \\
Overall Appraisal & & &
\end{tabular}

Clark ranks in the top tier in all areas of the survey bar one - her legislative achievements. Many of the Clark era achievements are credited to her senior ministers - Steve Maharey, Michael Cullen and Annette King all provided a massive contribution towards the legislative accomplishment. ${ }^{161}$ However, it is her party management where Clark manages to shine, gaining the top score of all Prime Ministers assessed in the survey. Clark was regarded as a highly effective manager - in stark contrast to the Prime Ministers of the fourth Labour government. Her control over her party asserted her authority in the House and against her opposition through a period of politics filled with broken promises and policy upheaval, and bought forth a new echelon of leadership - never seen before by a female in domestic politics, and certainly one that had not been seen by any Prime Minister since the early 1980's.

One of the most compelling factors to explain the momentum in rankings for Clark is assessing to what extent her career post-office has had an influence on her placing. As the only

\footnotetext{
${ }^{159}$ See Jon Johansson. The Politics of Possibility: Leadership in Changing Times. p. 104.

160 Ibid., p. 105.

${ }^{161}$ See Michael Bassett. 2017. New Zealand's Prime Ministers: From Dick Seddon to John Key. Mangawhai: David Ling. p. 467-469.
} 
Prime Minister of the top three still living, Clark has an advantage in the fact that she is a Prime Minister that all respondents would have lived through and will still continue to observe throughout her political career. Through her high profile post-office career with the United Nations, and her subsequent work on gender equality in leadership, Clark has managed to capture the values of modern day politics in New Zealand, heightening her appeal amongst those more liberal leaning citizens. ${ }^{162}$

The ranking of Seddon in third place provides possibly the biggest and most unexpected surprise of the 2018 study, even more so than Savage placing in the top position. In the 2011 survey, the authors noted that it was 'unsurprising given the arch-command of his political environment for well over a decade that Seddon has maintained his standing as New Zealand's top-ranked prime minister. ${ }^{\text {'63 }}$ However, the rise of Savage and Clark as the top two Prime Ministers has prevented Seddon from having a clean sweep over the three consecutive studies that have now been conducted. Additionally, the recency of both Prime Ministers in contrast to Seddon may be playing a part - as the generations further from Seddon's time in office become the participants of this research, there is a chance that Seddon's domination of power is being underappreciated by respondents as newer, more easily remembered Prime Ministers move into the top tier.

Table 5.5. Comparison of Seddon Rankings 1998/2011/2018

\begin{tabular}{lccc}
\hline & $\begin{array}{c}\text { Sheppard } \\
(1998)\end{array}$ & $\begin{array}{c}\text { Johansson } \\
\text { and Levine } \\
(2011)\end{array}$ & 2018 \\
\hline $\begin{array}{l}\text { Overall Ranking (by } \\
\text { categories) }\end{array}$ & 1 & 1 & 3 \\
Leadership Qualities & 1 & 1 & 5 \\
Parliamentary Skills & 1 & 1 & 8 \\
Party Management & 1 & 1 & 5 \\
Crisis Management & 2 & 2 & 7 \\
Legislative Achievements & 1 & 1 & 3 \\
Overall Appraisal & 1 & 2 & 3 \\
\hline
\end{tabular}

Despite Seddon's slight fall, he still embodies an extremely high depiction of political leadership that will not soon be forgotten. Seddon was blunt, and was not one to be

\footnotetext{
${ }^{162}$ For more information on Clark's work on gender equality, her latest book can be referred to. See Helen Clark. 2018. Women, Equality, Power. Allen \& Unwin: Auckland.

${ }^{163}$ See Jon Johansson and Stephen Levine. 'Evaluating Prime Ministerial Performance: The New Zealand Experience.' p. 302.
} 
'encumbered with either theories or ideals.' 164 Seddon saw what needed to happen, and did everything in his power to get there without vying off course. His domination of power has never been reached by any other Prime Minister - with no leader ever meeting his achievement of winning five consecutive general elections. Seddon's drive and efficient methods in office allowed him to achieve results that others would have not even thought to attempt. ${ }^{165}$ To sum up the character of Seddon in one paragraph, Sinclair notes the following.

'Seddon was shrewd, resilient, devious in method, straightforward in speech, conciliatory to his foes. He grew in political stature as well as authority. One after another he surmounted crises which would probably have led to the defeat of any previous Premier. Most of the Liberal legislation might never have reached the statute book but for his astute leadership.' 166

Seddon's death in office from a heart attack allows him to be the only Prime Minister in the top three to meet all the trends associated with an elevated reputation - being a big change Prime Minister, serving for a long period of time, and passing whilst still holding office. Seddon built upon the existing policies of John Ballance when assuming the top job, and subsequently took them further than the architect may have been able to. He redefined the Liberal Party and policy in ways that never could have been imagined, all whilst retaining the elements of a pragmatic and genuine humanitarian. ${ }^{167}$ Should future generations perceive Seddon in the same way as what has been seen previously, he will continue to be remembered as one of the transformational figures in New Zealand's domestic politics, and subsequently be amongst the top tier in terms of Prime Ministerial performance.

\footnotetext{
${ }^{164}$ See Jon Johansson and Stephen Levine. 'Evaluating Prime Ministerial Performance: The New Zealand Experience.' p. 302.

165 See G. H Scholefield, 1946. Notable New Zealand Statesmen: Twelve Prime Ministers. Auckland:

Whitcombe \& Tombs. p. 176.

${ }^{166}$ See Keith Sinclair. A History of New Zealand. p. 194.

${ }^{167}$ Such a statement regarding Seddon's performance in office was made 70 years later by Robert Muldoon, and Seddon was viewed by him as 'the very exemplar of New Zealand-style prime ministerial leadership'. See Jon Johansson and Stephen Levine. 'Evaluating Prime Ministerial Performance: The New Zealand Experience.' p. 302.
} 
The 2018 exercise saw the entrance of two new Prime Ministers, John Key (2008-2016) and Bill English (2016-2017). As the two most recent Prime Ministers to serve, it was anticipated that such a factor could influence their rankings. However, such a trend does not seem to be overtly present.

The first new entrant, John Key, enters the rankings in $9^{\text {th }}$ place overall. Beginning his term in 2008, Key led the fifth National Government until his unexpected resignation in 2016, less than a year out from the 2017 general election. Key provides an intriguing analysis towards his leadership in office. As one of the shortest serving Members of Parliament prior to holding office, Key had been in Parliament for just six years before being elected Prime Minister. ${ }^{168}$ Fulfilling a childhood dream of being in the top job, Key has been said to have been the most 'comfortable in his skin as Prime Minister since Gordon Coates'. ${ }^{169}$ Throughout his leadership, Key was well-received by much of the nation, and came across as very straightforward and open towards both citizens and the media. ${ }^{170}$ Key was a very charismatic leader, and was considered to have the same levels of engagement as Savage. ${ }^{171}$

Key presented an extremely unified front towards the nation, and managed to garner and maintain high levels of public support during his time in office. Additionally, Key deserves an honourable mention for the crisis periods in which he held office. To some extent he could be considered a crisis Prime Minister. Inheriting the fallout from the Fifth Labour Government regarding the Global Financial Crisis in his election in 2008, Key managed to navigate the nation through these events with relatively little disruption. Subsequently, Key went on to govern through a series of disasters, including multiple major South Island earthquakes and the 2010 Pike River mining disaster.

Despite the significant public appreciation that Key held, his rankings of performance categories differ across the board. Key was ranked well across the top and middle tiers by respondents, with an impressive standout in the performance category of party management. Key entered in second place, behind his predecessor Helen Clark. Despite this, Key was also

\footnotetext{
${ }^{168}$ See Michael Bassett. 2017. New Zealand's Prime Ministers: From Dick Seddon to John Key. p. 494.

${ }^{169}$ Ibid., p. 495

${ }^{170}$ Ibid.

${ }^{171}$ Ibid.
} 
ranked towards the lower end of the spectrum in some categories, with a $17^{\text {th }}$ place ranking in the category of legislative achievements. Whilst the level of respect and appreciation that Key held from the public should have seen him enter rankings higher than what he did - much like what was seen by the likes of Savage, Fraser and Seddon - his unexpected resignation could have played a part in causing him to enter lower than anticipated. Leaving his party in the lurch, with no real explanation for his resignation whilst National was polling at an all-time high, Key's lower overall ranking in the top tier and in some performance categories could be a result of a slight public backlash for failing to secure the National Party a fourth term.

The second new entrant of the 2018 study was Bill English, who ranked $19^{\text {th }}=$ in the survey. Despite being the most recent prime minister in the survey, English was ranked poorly by most respondents, with no major standouts in any of the performance categories unlike his predecessor. English shares his $19^{\text {th }}$ place ranking with two other short-term Prime Ministers, Geoffrey Palmer and John Marshall (best known for his contribution to the economic survival of New Zealand when Britain joined the European Economic Community (EEC), as opposed to his brief tenure of being Prime Minister). ${ }^{172}$ In the overall appraisal of performance, English slipped further down the rankings, placing in $22^{\text {nd }}$.

Whilst English was ranked below-average in most of the performance categories, he was given some credit by respondents in the party management category, ranking in $15^{\text {th }}$ place. Although not ranking in the top tier for this category, English is recognised by respondents for his ability to keep the National Party in shape compared to a failing Labour Party, despite an unexpected leadership change and subsequent party reshuffle just nine months out from the general election. ${ }^{173}$ Furthermore, English managed to maintain a united party front to the public, with poll results barely moving in the months following the resignation of Key. Despite his inability to negotiate a successful coalition government with New Zealand First following the election, English must be given credit for maintaining high support for his party through until his resignation in February 2018.

\footnotetext{
172 See Ian Grant. Public Lives: New Zealand's Premiers and Prime Ministers 1856-2003. p. 135.

${ }^{173}$ See Morgan, Gary, and Michele Levine. 2017. 'National Party Support up Slightly in January as New Prime Minister Bill English Returns from 'Introductory Tour' to Europe: Roy Morgan Poll January 2017. Melbourne. Roy Morgan and One News. 2017. ‘One News Colmar Brunton Poll 11-15 February 2017.’ Auckland. Colmar Brunton.
} 
Although English proved not to be a standout Prime Minister with respondents, one noted that his previous tenure of Deputy Prime Minister under Key will be what he is remembered for. The respondent regarded that his 'performance after John Key was abysmal, and he will be instead best known as an outstanding deputy.' English's involvement in a range of roles prior to being Prime Minister, including the Minister of Health (16 December 1996 2 February 1999) and Minister of Finance (19 November 2008 - 12 November 2016), have shaped his legacy and will continue to do so for years to come.

\section{The best Prime Minister New Zealand 'never had'}

The final component of the survey, which acted as a more speculative section, provided an insight into who respondents believed was the best Prime Minister New Zealand never had. Whilst this section elicited fewer responses than the main components of the survey, those that were provided gave a greater insight into who participants believed to be potential political leaders. One respondent questioned what the performance of Sir Michael Cullen would have been like had he been Prime Minister, asking if he would have performed as well in the top spot as he did as the deputy. Subsequently, another respondent suggested John A. Lee due to his 'dynamic, colourful character', but then went on to argue that his autocratic tendencies probably would have resulted in him being a terrible Prime Minister. Former Green Party co-leader Meteria Turei received multiple mentions from respondents, with some mentioning the importance of having a female Māori Prime Minister, which could indicate a significant shift in radical attitudes. Others mentioned included David Shearer (Labour), Brian Tallboys (National), Jim Anderton (Labour) and Sir Edmund Hillary (a non-politician, the conqueror of Mt. Everest).

\section{The Schlesinger Models}

For the first time in New Zealand, research was conducted for this thesis that takes on a complete replication of the Schlesinger surveys. Whilst these surveys have inspired elements of the previous academic exercises that have been conducted, there has been no known exact replication until now. 


\section{Single question methods versus multi question methods}

As stated earlier, this research investigates a set of aims and factors that may have an impact on the performance rankings of former Prime Ministers. This research has assessed a claim made by Arthur Schlesinger Jr. in 'Rating the Presidents: Washington to Clinton', in which he made the claim that a more complex survey will produce the same results as a more simplified one, despite a more comprehensive set of methodology. ${ }^{174}$ To support his hypothesis, Schlesinger investigates the results of his own survey conducted on the performance of US Presidents in 1997, with others conducted in the 1970's and 1980's with more pretentious methodologies. With scholars stating that the Schlesinger surveys were too 'impressionistic and subjective', many turned to the introduction of criteria and yardsticks to rank performance against. ${ }^{175}$ The intention behind such changes in methodology would be that the results would be more accurate and scientific. ${ }^{176}$ However, Schlesinger argued that the yardsticks and criteria proved too general, and that the surveys as a whole appeared too lengthy and intimidating for respondents to complete. ${ }^{177}$ Schlesinger notes the critiques of Thomas A. Bailey, who regarded the two earlier Schlesinger polls as a 'Harvard-eastern elitist-democratic plot'. ${ }^{178}$ Bailey went on to create his own survey ranking Presidents in 1966, in which he emerged with results similar to those seen in the Schlesinger rankings, despite using 43 different yardsticks for respondents to judge a president's performance against. ${ }^{179}$

With this research undertaking multiple surveys with different methodologies, it was anticipated that Schlesinger's claim would be false in this context, and that different results would arise from each survey. This cannot be further from the truth. Despite such differences in methodology, the survey that replicated the Schlesinger model has produced near similar results to the 2018 survey, and once again proves Schlesinger's claim to have been sound.

When observing the results of the survey using the Schlesinger methodology, similar comparisons can be made to the 2018 survey. The top three Prime Ministers remain the same

\footnotetext{
${ }^{174}$ See Arthur. M. Schlesinger Jr. 'Rating the Presidents: Washington to Clinton.' p. 181-182.

175 Ibid., p. 181.

176 Ibid.

177 Ibid. p. 182.

178 Ibid. p. 181.

${ }^{179}$ See Kenney, Patrick J. and Tom W. Rice. 1998. 'The Contextual Determinants of Presidential Greatness.' Presidential Studies Quarterly. 18. (1): p. 161-69, and Arthur. M. Schlesinger Jr. 'Rating the Presidents: Washington to Clinton.' p. 181-182.
} 
as in the overall appraisal of the 2018 survey, although rankings are slightly shuffled. Savage once again takes the top spot, reaffirming the notion of Savage being regarded as New Zealand's greatest Prime Minister, and again alluding to the high levels of respect directed by the public towards him. Savage was noted by respondents as great for 'breaking the mould of conservatism and austerity imposed by his United-Reform Coalition predecessors, and redefining New Zealand under his leadership of the First Labour Government during the Great Depression.' Seddon enters in second place, up one position from his ranking in the 2018 survey, noted for overseeing many transformational and foundational reforms, and for both leading and following the popular politics of his time.

Table 5.6. Comparison of 2018 results with results following Schlesinger methodology

\begin{tabular}{|c|c|c|c|}
\hline Prime Minister & 2018 results & $\begin{array}{l}\text { Schlesinger } \\
\text { replication results }\end{array}$ & $\begin{array}{c}\text { Difference } \\
\text { from } 2018 \\
\text { results }\end{array}$ \\
\hline Atkinson, Harry & 20 & 21 & -1 \\
\hline Ballance, John & $9=$ & $8=$ & +1 \\
\hline Bolger, Jim & 15 & $10=$ & +5 \\
\hline Clark, Helen & 5 & 4 & +1 \\
\hline Coates, Gordon & 18 & 12 & +6 \\
\hline Domett, Alfred & $23=$ & $29=$ & -6 \\
\hline English, Bill & 22 & 23 & -1 \\
\hline Forbes, George & 34 & $29=$ & +5 \\
\hline Fox, William & 32 & 25 & +7 \\
\hline Fraser, Peter & $1=$ & 3 & -2 \\
\hline Grey, George & $23=$ & 18 & +5 \\
\hline Hall, John & $23=$ & 26 & -3 \\
\hline Holland, Sidney & 16 & $19=$ & -3 \\
\hline Holyoake, Keith & $7=$ & $10=$ & -3 \\
\hline Key, John & 13 & 14 & -1 \\
\hline Kirk, Norman & 4 & 5 & -1 \\
\hline Lange, David & $9=$ & 7 & +2 \\
\hline Marshall, John & 27 & $16=$ & +11 \\
\hline Massey, William & $7=$ & 13 & -6 \\
\hline Moore, Mike & $30=$ & 27 & +3 \\
\hline Muldoon, Robert & 17 & 31 & -14 \\
\hline Nash, Walter & 21 & $16=$ & +5 \\
\hline Palmer, Geoffrey & 26 & 24 & +2 \\
\hline Pollen, Daniel & 33 & 32 & +1 \\
\hline Rowling, Wallace & 28 & 22 & +6 \\
\hline Savage, Michael & $1=$ & 1 & $\mathrm{NC}$ \\
\hline Seddon, Richard & 3 & 2 & +1 \\
\hline Shipley, Jenny & $30=$ & 28 & +2 \\
\hline Stafford, Edward & $9=$ & 6 & +3 \\
\hline Stout, Robert & $9=$ & $19=$ & -10 \\
\hline Vogel, Julius & 6 & 15 & -9 \\
\hline Ward, Joseph & 14 & $8=$ & +6 \\
\hline Weld, Frederick & 19 & 33 & -14 \\
\hline Whitaker, Frederick & 29 & 34 & -5 \\
\hline
\end{tabular}


Fraser drops two positions from his first equal ranking alongside Savage to the third place position. Described by a respondent as a 'principle [sic] architect of a policy regime that lasted more than half a century', Fraser embodied many of the characteristics of a successful leader, both in his role as Prime Minister and as Minister of Education. A factor that could point to his slight drop in ranking from the 2018 results was noted by multiple respondents, who stated that Fraser was a great innovator in, and achieved more, in his role as Minister of Education than he did during his time as Prime Minister. Furthermore, one respondent noted that whilst Fraser did embody the qualities of a great leader, he was severely let down by being unable to ensure a credible successor and coming to the realisation too late that that successor should have been Sir Arnold Nordmeyer.

Despite the slight shuffling in rankings, the results of the survey once again reaffirm the status of Savage, Seddon and Fraser as the faces of exceptional leadership in New Zealand. As mentioned in the 2011 survey, if New Zealand were to have its own Mount Rushmore, it would be these three faces carved upon it. ${ }^{180}$ This remains true seven years later, regardless of a changing political context. Whilst some subsequent Prime Ministers may come close to reaching the same performance levels as Savage, Seddon and Fraser, none - with the exception of Clark - have managed yet to have been regarded as such an esteemed figure in New Zealand politics. They each go above and beyond at fulfilling the criteria given for being a successful political leader, each delivering a pragmatic, charismatic and intelligent persona, and adapting well towards the contexts in which they held office. As one respondent noted on their survey, each managed to 'change the way New Zealanders saw themselves, saw government, and saw the country.'

As seen in the results of the 2018 survey, a series of factors appeared prevalent in responses determining the rankings of former Prime Ministers: longevity, death in office and 'big change' or crisis Prime Ministers. Similar trends can be noted in these survey results, with each factor also playing a part in determining Prime Ministerial greatness. Once again, five of the seven long-serving Prime Ministers appear in the top ten (Seddon $2^{\text {nd }}$, Fraser $3^{\text {rd }}$, Clark $4^{\text {th }}$, Bolger $10^{\text {th }}=$ and Holyoake $10^{\text {th }}=$ ), with only Massey and Muldoon outside of the top tier.

\footnotetext{
${ }^{180}$ See Jon Johansson and Stephen Levine. 'Evaluating Prime Ministerial Performance: The New Zealand Experience.' p. 314.
} 
Despite the results proving that longevity remains a factor in being classified as an 'excellent' Prime Minister, some respondents also noted the fact that time in office did not play a part in their rankings. One respondent noted the following on their response.

'Electoral success or length of time in office is not the overwhelming criteria for greatness: in fact, of my three 'great' prime ministers, two (Savage and Lange) only won two elections, and the other (Ballance) only one. On the other hand, it has to be taken into account: almost all of our longer-serving prime ministers are in the 'near great' category, with the exception of Robert Muldoon.'

Death in office also prevailed once again in the Schlesinger replication, with four of the five Prime Ministers who died in office appearing in the top ten (Savage $1^{\text {st }}$, Seddon $2^{\text {nd }}$, Kirk $5^{\text {th }}$ and Ballance $\left.8^{\text {th }}=\right)$. Massey was the only Prime Minister who died in office to fall outside of this category, unlike his position in the 2018 survey. Such a trend once again indicates the sympathetic notion of New Zealanders overall, rather than changes in different methods in surveying. Additionally, the third trend of being a big change or crisis Prime Minister dominates the top ten again, with seven of the nine Prime Ministers considered in this category entering in the top tier. Vogel, Lange and Bolger provide the biggest changes in this trend, with Vogel falling out of the top ten, despite being considered the architect of the first transformational period in domestic politics. Lange and Bolger move into the top tier, with the former entering in $7^{\text {th }}$ place, and the latter in $10^{\text {th }}=$.

For most former Prime Ministers, their rankings tend to only differ marginally from those seen in the 2018 survey. Savage is the only Prime Minister to remain in the same position as the 2018 results, with other Prime Ministers moving only slightly in their rankings across the two different surveys. Twenty-two Prime Ministers moved five places or less, indicating a somewhat similar stance from respondents across the two surveys. Seven Prime Ministers moved between six and nine places in comparison to the 2018 results. When observing the Prime Ministers included in the top ten in contrast to the 2018 survey, the results show that nine Prime Ministers appear in the top tier of both surveys (Ballance, Clark, Fraser, Holyoake, Kirk, Lange, Savage, Seddon and Stafford). Bolger and Ward also fall into the top ten in the 
Schlesinger exercise, in contrast to Massey, Stout and Vogel in the 2018 survey. ${ }^{181}$ The two new entrants, John Key and Bill English, slip one place each in this survey to $14^{\text {th }}$ and $23^{\text {rd }}$ place respectively, indicating a similar perception of performance from respondents across both surveys.

Four Prime Ministers had changes of 10 places or more in comparison to the 2018 results. Robert Stout falls 10 places, from $9^{\text {th }}=$ to $19^{\text {th }}=$, whereas both Frederick Weld and Robert Muldoon fall 14 places each. John Marshall moves up 11 places, from $27^{\text {th }}$ in the 2018 survey to $16^{\text {th }}=$. Serving only briefly as Prime Minister, Marshall took office in February 1972 following the resignation of Holyoake, after a successful contest of the position against Robert Muldoon. Stepping into the leadership of a party that the public were becoming tired of, Marshall only served as Prime Minister for a brief period of time, with the Labour Party proving victorious in the November election under the leadership of Norman Kirk. Whilst Marshall had grand ideas for the reformation of the National Party, believing it had become stagnated and inflexible in its 12 years in power, the public perceived such reforms as insufficient, and grew tired of the worn out and out-of-touch government. ${ }^{182}$ The rise of Marshall provides a curious insight to Prime Ministerial performance rankings, one that could be attributed to the different methodology of each survey. As mentioned earlier, Marshall was best known for his role ensuring the economic survival of New Zealand following Great Britain joining the EEC. Whilst regarded as a great communicator and a tough negotiator during such a process, Marshall failed to take such skills across into his prime ministership. ${ }^{183}$ However, this survey asked respondents to rank each Prime Minister on a scale of great to failure, with no benchmarks to guide them on how to best do so. In contrast to the 2018 survey, where Marshall's ranking was dictated by five different performance categories detrimental to his time in the top office, these results could be reflecting his career in politics prior to being Prime Minister.

Regardless of relatively similar results to the 2018 survey, the replication of the Schlesinger surveys bought forth far more criticism and uncertainty from respondents. Multiple respondents noted the difficulty of assessing Prime Ministers without categories, comparable

\footnotetext{
${ }^{181}$ Due to some Prime Ministers gaining an equal placing with one another, the 2018 survey sees 12 Prime Ministers fall into the top 10 positions, whereas the Schlesinger exercise sees 11 Prime Ministers in this category. See Table 4.1 and Table 4.3 for further details.

182 See Ian Grant. Public Lives: New Zealand's Premiers and Prime Ministers 1856-2003. p. 138. and Michael Bassett. New Zealand's Prime Ministers: From Dick Seddon to John Key. p. 282.

${ }^{183}$ See Ian Grant. Public Lives: New Zealand's Premiers and Prime Ministers 1856-2003. p. 139.
} 
to the criticism seen towards the original Schlesinger surveys. Respondents noted the importance of the categories of political and electoral success, policy reform, popularity, competence, and managing difficult events, and argued that in some cases it proves too challenging to rank a leader's performance on an overall scale when attempting to take such different criteria into consideration. One respondent noted the following on their response.

'For me it is difficult to rank without any more granulated criteria. For example if one is ranking based on 'telegenic' appeal then David Lange could be ranked quite highly. But if the ranking criteria is the capacity to manage a Cabinet and to forge a consensus in the context of competing views then Lange does not rate as highly as the person who succeeded him. Then there is the relevance of electoral success - does one rank a Prime Minister in terms of how many elections she or he 'wins'? We also have the fact that a Prime Minister is the Head of Government, the chair of Cabinet, and the Leader of his or her Partyso we have a role that has multiple dimensions to it and we need to determine what weighting to give to each. My sense is that to be great one needs to be great at all three. Clark was an effective Leader of her Party but her approach to Cabinet was - in the view of some - characteristic of a martinet more than a leader per se.'

The wildcard: Robert Muldoon

Regarded as one of New Zealand's most controversial Prime Ministers and known for his unconventional way of leading the nation, Robert Muldoon provides a unique case of rankings across both surveys. ${ }^{184}$ Muldoon has had an interesting appraisal of his performance since his time in office, with many being deeply opposed to his politics. Despite this, some assessments show the opposite. Keith Jackson regarded Muldoon as one of two Prime Ministers to make the greatest impression on New Zealand, for his 'Napoleonic' approach to winning politically. ${ }^{185}$ The other was Kirk - a Prime Minister on the polar opposite side of the political spectrum. Muldoon has had further praise from Barry Gustafson, who considered him one of the eight great political figures in New Zealand, whilst former Speaker of the House of

\footnotetext{
${ }^{184}$ See Ian Grant. Public Lives: New Zealand's Premiers and Prime Ministers 1856-2003. p. 152.

${ }^{185}$ See David Gee. 1993. 'Keith Jackson: Analyst of New Zealand Political Leaders.' 21 July. The Press: Christchurch. p. 13.
} 
Representatives Jonathan Hunt considered Muldoon in the top five Prime Ministers he has seen in office. ${ }^{186}$

Previous scholarly assessment has consistently ranked Muldoon in the top or mid-tier, with him placing in $9^{\text {th }}$ place in the 1998 survey and $11^{\text {th }}$ place in the 2011 exercise (each by overall ranking of performance categories). From the perspective of overall appraisal, Muldoon ranked similarly - in $9^{\text {th }}$ place in the former study and $16^{\text {th }}=$ in the latter. Asserting himself solidly amongst the mid-tier of Prime Ministers, the 2018 survey consistently followed suit, with Muldoon placing in $12^{\text {th }}$ place by overall ranking of performance categories, and $17^{\text {th }}$ place by overall appraisal. As time goes on, the survey results have shown Muldoon's rankings decreasing - a reflection of possibly ongoing public disdain towards his actions in office, and showing a consensus of political context at the time. As the liberal generation moves further through into political engagement, it would be expected to see Muldoon's ranking suffer even more in further research as a result of his disruptive actions and policies.

The replication of the Schlesinger surveys provides the most surprising ranking towards Muldoon's leadership. Muldoon was ranked in $31^{\text {st }}$ place - 14 places lower than what was seen in the overall appraisal of the 2018 survey, and a drop in rankings that only one other Prime Minister managed to achieve, with Weld falling the same amount of places. When ranked on an overall scale, Muldoon enters further into the low-tier, in contrast to his higher rankings when observing set criteria. Where Muldoon had lesser known achievements that ranking by criteria allowed appropriate responses for, ranking on an overall scale causes respondents to focus solely on his negative leadership - namely his disruption towards the economy, his electoral manipulation and his disruption of the Springbok tour, and his overall irrationality and combativeness. One respondent noted the following on their response.

'I regard Robert Muldoon as our worst Prime Minister. His cynical manipulation of the Springbok tour for electoral advantage, and refusal to confront economic realities, putting New Zealand deeply into debt, left scars on the country's economy and social fabric that have still not completely disappeared more than 30 years later. But for the quirks of the first-past-the-post electoral system, he would have been ejected from office after only three years.'

${ }^{186}$ See Ian Grant. Public Lives: New Zealand's Premiers and Prime Ministers 1856-2003. p. 21. 
Muldoon provides the greatest amount of fluctuation in perceptions of political leadership, with some regarding him as great, and others the complete opposite. Whilst he did manage to fulfil some of the components of a successful leader - he was considered a master of television, and his ability to communicate with 'the ordinary bloke' made him both mesmerising and a television and radio favourite - he was also regarded as one of the biggest and most dangerous threats to New Zealand's democratic traditions. ${ }^{187}$ Although his leadership was forceful unique in the sense that power was centralised to a degree that had never been seen before (he served both as Prime Minister and as Minister of Finance) - his recklessness, impetuosity and ruthlessness make it hard to overlook his failures in office. ${ }^{188}$ Of all former Prime Ministers, no one can fulfil the title of 'wildcard' as much as Muldoon.

\section{The generational shift: a new survey}

The idea of age-based politics provides another outlook on the results of this research, and the third survey was created purely to investigate this phenomenon. Regarded as one of the 'most basic social categories of human existence and a primary factor in all societies for assigning roles and granting prestige and power', age has become prominent in politics,

particularly in regard to participation and activism. ${ }^{189}$ Age is becoming increasingly popular in determining political outcomes, with scholars noting that the more traditional explanations of political behaviour, such as social class, political party and personality, are 'losing their potency', and age is instead being used to determine and understand political behaviour. ${ }^{190}$ It is noted that age holds an impact on voting rates, with there being greater political involvement as people age and 'begin to assume family and career responsibilities and become more integrated into their communities.' ${ }^{191}$ Subsequently, age can be attributed to the level of political knowledge one holds. Scholars state that political knowledge can be defined as either factual knowledge, which covers information about events, personalities or institutions, or background knowledge, which refers to political concepts, ideological terms and the

\footnotetext{
187 See Ian Grant. Public Lives: New Zealand's Premiers and Prime Ministers 1856-2003. p. 154-155.

${ }^{188}$ See Jon Johansson. 2004. 'Muldoon and Character.' In Margaret Clark (ed). 2004. Muldoon Revisited. Palmerston North: Dunmore. p. 269- 271.

${ }^{189}$ See Richard G. Braungart and Margaret M. Braungart. 1986. 'Life-Course and Generational Politics.' Annual Review of Sociology. Vol. 12. p. 205.

190 Ibid., p. 208.

${ }^{191}$ See Russell J. Dalton. 2008. Citizen Politics: Public Opinion and Political Parties in Advanced Industrial Democracies. $5^{\text {th }}$ Ed. Washington D.C: CQ Press. p. 60.
} 
procedures in which political institutions operate. ${ }^{192}$ For the purpose of this research, the third survey has been conducted in order to test the levels of factual knowledge of participants. ${ }^{193}$

The third survey was implemented in order to assess levels of political knowledge through recall rates amongst participants, and to observe whether significant trends can be attributed to generational differences. With the third survey adopting a very different methodology in contrast to the 2018 survey and the Schlesinger replication, it becomes increasingly difficult to assess whether the same trends of longevity, time in office and being a big change or crisis Prime Minister appear obvious in results. Instead, two prominent movements can be observed in the results of the third survey: one attributed to the factual knowledge of young people, and the other indicating a political shift on the political position spectrum within the demographic, both of which are undetectable in the 2018 study and the Schlesinger replication.

By testing recall rates using the third survey, an indication of the levels of factual political knowledge is able to be explored. As outlined earlier, this survey was administered by asking respondents to name who they believed to be the best and worst Prime Ministers New Zealand has had. No participant was given a list of former Prime Ministers, and they were asked to exclude the current Prime Minister from their mentions. When observing the results from each survey, the levels of political knowledge remain similar over the three university courses. The more recent Prime Ministers who have served in office appear more prominent in survey mentions, alluding somewhat to the impact of the recency effect, and indicating a higher level of knowledge towards those Prime Ministers who have served most recently in office, in contrast to those who have served earlier. Scholars have argued that each different age demographic has 'come into existence within a certain historical and political setting', which supports the idea of having political figures that a particular demographic is drawn closer to. ${ }^{194}$ In this case, the Prime Ministers who have served in office since the 1970's appear more prominent in a student's political knowledge due to it being closer to the era in which they came into existence. In contrast, those Prime Ministers who were deemed to reflect the top tier

\footnotetext{
192 See Ian McAllister. 1998. 'Civic Education and Political Knowledge in Australia.' Australian Journal of Political Science. 33 (1): p. 11.

${ }^{193}$ See Ian McAllister. 1998. 'Civic Education and Political Knowledge in Australia.' p. 11, and David Denver and Gordon Hands. 1990. 'Does Studying Politics Make a Difference? The Political Knowledge, Attitudes and Perceptions of School Students.’ British Journal of Political Science. 20 (2): p. 265.

${ }^{194}$ See Richard G. Braungart and Margaret M. Braungart. 'Life-Course and Generational Politics.' p. 206.
} 
of leadership in both the 2018 survey and the Schlesinger replication (Savage, Fraser and Seddon), were infrequently mentioned by students in the third survey, indicating lower levels of knowledge towards the earlier serving Premiers and Prime Ministers.

Of all the $19^{\text {th }}$ century Premiers that held office, no more than four were given a mention in each of the surveys. The first year New Zealand politics class mentioned four $19^{\text {th }}$ century Premiers - Ballance, Fox, Grey and Seddon - although the number of mentions of these four figures was minuscule. With 152 surveys completed, there were a possible 304 mentions that could be gained (Prime Ministers could be mentioned up to twice on each survey - either as 'best' or 'worst'). However, the four $19^{\text {th }}$ century Premiers only gained 13 mentions between them (six 'best' and seven 'worst'). In contrast, the five most recent Prime Ministers who have held office - English, Key, Clark, Shipley and Bolger - received over half of the available mentions, with 158 between them. Similar patterns occurred in the surveys distributed to other classes, with the third year class mentioning two $19^{\text {th }}$ century Premiers in the results from March 2018, followed by three in the June 2018 results, and the postgraduate class only mentioning Seddon. Nearly every Prime Minister from Muldoon onwards is mentioned at least once across the third year and postgraduate results. Such a pattern points towards a more significant database of knowledge of the more recent Prime Minsters - which could well be attributed to the age demographic.

The second trend prominent in the third survey indicates a political shift in ideologies amongst the demographic. Research has shown that, in general, youth tend to lean towards centre or left of centre on the political positioning spectrum. ${ }^{195}$ It is argued by scholars comparing different demographics in politics that young people are more likely to be politically liberal than those of older demographics. ${ }^{196}$ The outcomes of the third survey can attest to such claims across the results from all three courses. Whilst no student was asked to give any identifying notions on their response, including their political inclination, the breakdown of survey results show the left leaning tendencies of the more recent generations.

\footnotetext{
${ }^{195}$ See Richard G. Braungart and Margaret M. Braungart. 'Life-Course and Generational Politics.' p. 210. ${ }^{196}$ Ibid.
} 
Table 5.7. Breakdown of student assessment by position of political party

\begin{tabular}{l|cc|cc|cc|cc}
\hline Political Position & \multicolumn{2}{|c|}{ Pols 111 (March) } & \multicolumn{2}{|l|}{ Pols 353 (March) } & Pols 353 (June) & \multicolumn{2}{l|}{ Pols 428 (March) } \\
\hline & Best & Worst & Best & Worst & Best & Worst & Best & Worst \\
Center-Right & 4 & 8 & 4 & 6 & 2 & 5 & 1 & 3 \\
Centre & 1 & 1 & 1 & 0 & 1 & 1 & 1 & 0 \\
Centre-Left & 6 & 3 & 5 & 3 & 6 & 2 & 4 & 0 \\
Independent & 1 & 2 & 0 & 1 & 1 & 1 & 0 & 0 \\
\hline
\end{tabular}

Table 5.7 shows the breakdown of Prime Ministers mentioned by position of political party. In every survey, the Prime Ministers from political parties identifying as left of centre were mentioned most as 'best' Prime Ministers, whereas those from political parties identifying as right of centre were mentioned most as 'worst' Prime Ministers. ${ }^{197}$ On the whole, the third survey shows a lean towards the left in the surveys in all three political science courses.

In contrast to the results of the 2018 survey and the Schlesinger replication, a slight political shift towards the left can be witnessed. Whilst many of the Prime Ministers from parties identifying as left of centre were highly ranked, such as Savage, Clark and Fraser, many of those from parties right of centre were also highly regarded by participants. Robert Muldoon provides the most obvious contrast. Where he ranked in $12^{\text {th }}$ position in the 2018 survey, he was ranked overwhelmingly poorly in the third survey, receiving the most 'worst' mentions of any Prime Minister by a significant margin. Respondents noted him as being far too narrow minded and unpredictable, and leaving the New Zealand economy in a very troubled position. David Lange provides a similar comparison. Whilst noted in previous surveys that Lange's leadership was somewhat unstable and ineffective in charge of his own party, Lange was steadily mentioned as one of the 'best' Prime Ministers in the third survey. Respondents overwhelmingly mentioned his anti-nuclear policy as their reasoning behind their rankings, which could somewhat be attributed to a left-leaning generational shift, with many liberals supporting the eradication of nuclear weapons across the globe.

\section{The impact of the 'recency effect'}

In addition to observing the effects of differences in methodology on ranking results, the idea of the recency effect is observed in this research, to determine whether it may have had an

\footnotetext{
${ }^{197}$ Parties identifying as right of centre include the National Party, the United Party and the Reform Party. The Labour Party is the only party identifying as left of centre, and the Liberal Party is the only centre party. For those who held office as an independent, they are included in their own category of 'independent' as opposed to being categorised.
} 
impact on results. As mentioned earlier, the recency effect refers to a psychological idea that forms part of the serial-position effect. ${ }^{198}$ The recency effect supports the idea that when recalling a list of items that have been read by a participant, those items towards the end of the list are recalled first as they are the most recent in the participant's mind. ${ }^{199}$

When investigating a possible recency effect in each survey, slight observations can be made, including across the surveys conducted in 1998 and 2011. The recency effect could be said to have come into play when observing the mentions that each Prime Minister has received, with those serving later in office receiving more mentions in most cases than those who served earlier. However, the recency effect has had very little impact on the positioning of Prime Ministers in the rankings as a whole. The 1998 survey saw Jim Bolger, David Lange and Geoffrey Palmer each receive the most mentions from respondents, with 28 mentions each. ${ }^{200}$ Despite this, each of these Prime Ministers ranked outside of the top ten, indicating that being more well known by the public has little to no influence over their place in the results. In contrast, the three earliest Prime Ministers assessed received far fewer mentions from respondents, with Fox receiving six, Stafford eight and Domett four. ${ }^{201}$ Once again, no impact on results can be linked to having fewer mentions, with Stafford still managing to place in $10^{\text {th }}$ place in the rankings. Likewise, when observing Stafford's positioning in the 2011 survey, the same trend has also occurred. ${ }^{202}$

Both the 2018 survey and the Schlesinger replication mimic the recency trends seen in the existing studies conducted in New Zealand. The more recent Prime Ministers - those who have held office in the last 40 years - gained the most mentions in each survey from respondents, and the $19^{\text {th }}$ century Premiers were frequently overlooked. In contrast, the survey used to test the understanding and knowledge of students at Victoria University of Wellington

\footnotetext{
${ }^{198}$ Also coined by Herman Ebbinghaus, the serial-position effect refers to the overall concept of recall accuracy, encompassing both the recency effect (to recall that at the bottom of a list first) and the primary effect (to recall that at the top of a list first). See Herman Ebbinghaus. 2013. 'Memory: A Contribution to Experimental Psychology.'

${ }^{199}$ See Herman Ebbinghaus. 2013. 'Memory: A Contribution to Experimental Psychology.' and James Deese \& Roger A. Kaufman. 'Serial Effects in Recall of Unorganized and Sequentially Organized Verbal Material.' p. 180.

${ }^{200}$ See Simon Sheppard. 'Ranking New Zealand's Prime Ministers.' p. 87.

${ }^{201}$ Ibid.

202 The 2011 survey saw the most recent Prime Ministers (Clark, Shipley, Bolger, Palmer, Lange, Muldoon) receive more than 40 mentions from respondents, and the earliest Prime Ministers (Fox, Stafford, Domett, Whitaker and Weld) receive less than 12. See Jon Johansson and Stephen Levine. 'Evaluating Prime Ministerial Performance: The New Zealand Experience.' p. 305.
} 
was where the possible implications of the recency effect proved most prominent. As previously observed, each survey tended to move further towards more recent Prime Ministers in comparison to those who served earlier in office. The levels of political knowledge for those earlier serving Prime Ministers is limited, and a recency effect prevails to some extent. Overall, whilst a recency effect exists slightly across results, it does not do so in the way that experiments testing the theory have seen before, and its hypothesis does not prove true in this context.

\section{'The first class, the familiar and the forgettable': A new way of ranking}

Although this research has assessed scholarly ways of ranking the performance of Prime Ministers, the title of this thesis allows an alternative, more generalised approach towards assessing leadership.

To be considered as 'first-class' embodies the highest standard of leadership, and those included in this category display numerous qualities and dimensions associated with outstanding performance in office. Those Prime Ministers assessed as first-class follow on from the results of the three surveys that have been conducted, with all Prime Ministers included in the top tiers displaying leadership in office that will allow them to continue to be remembered by the New Zealand public.

Table 5.8. 'The First-Class, the Familiar, and the Forgettable'

\begin{tabular}{lll}
\hline The First-Class & The Familiar & The Forgettable \\
\hline John Ballance & Jim Bolger & Harry Atkinson \\
Helen Clark & Bill English & Gordon Coates \\
Peter Fraser & Sidney Holland & Francis Dillon Bell \\
Keith Holyoake & Geoffrey Palmer & Alfred Domett \\
John Key & Bill Rowling & George Forbes \\
Norman Kirk & Jenny Shipley & William Fox \\
David Lange & Robert Stout & George Grey \\
William Massey & Joseph Ward & John Hall \\
Robert Muldoon & & William Hall-Jones \\
Michael Savage & & Thomas Mackenzie \\
Richard Seddon & & John Marshall \\
Edward Stafford & & Mike Moore \\
Julius Vogel & & Walter Nash \\
& & Henry Sewell \\
& & George Waterhouse \\
& & Daniel Pollen \\
& & Frederick Weld \\
& & Frederick Whitaker
\end{tabular}


The first-class category fairly represents Prime Ministers considered responsible for transformational periods in domestic politics. Additionally, those Prime Ministers who served during preparatory phases for said transformational periods are also acknowledged, with both Kirk and Ballance falling into this category. The Prime Ministers who ranked highly across all surveys - Clark, Holyoake, Massey and Stafford - are also seen, each providing a first-class standard of leadership for successive Prime Ministers to live up to. Likewise, Key is included for his outstanding ability to unify both his party and the nation to a great degree, and his subsequent leadership through various crises throughout his time in office.

As in various other aspects of this research, Robert Muldoon provides one of the most conflicting cases to assess. Whilst not first-class in his policies, it is only fair that Muldoon be considered in this category purely because of his way of leading. No other recent Prime Minister can compare to having the centralised power that Muldoon had, and to assess him as anything other than first-class would be a disservice to his time in office.

The familiar allows for the categorisation of Prime Ministers who did not reach the same levels of leadership that those in the first-class did, but still manage to hold some influence over the New Zealand public that will cause them to be remembered more than others. Jenny Shipley provides the most obvious case of a familiar Prime Minister - whilst not overly outstanding at any point during her time in office, Shipley will be remembered by generations to come as the first female Prime Minister. Bolger also provides a sound example of a familiar Prime Minister - whilst his survey rankings do not qualify him as first-class, his significant period in office causes him to hold a substantial amount of influence over political history.

Much like Muldoon, the positioning of English also provides a conflicting case, with uncertainty over whether he should be considered 'familiar' or 'forgettable'. At the present time, English can be deemed familiar due to being the most recent Prime Minister to leave office. However, with no defining moments during his Prime Ministership that propelled him to greatness, and having more influence during his previous tenures as Minister of Health and Minister of Finance, it can be argued that his time in office could evidently become forgettable. Future studies could see him fall further down the ladder as new and more memorable talent 
moves into the rankings, and cause his lacklustre time as Prime Minister to become forgotten over time.

The forgettable sums up those Prime Ministers on the lowest, most uninfluential tier of political leadership in office - those who have already been forgotten or will eventually be forgotten as Prime Ministers. Nearly all of the earlier serving $19^{\text {th }}$ century Premiers appear in this category, as an accurate depiction of how their time in office has already been forgotten by the public. Prime Ministers such as Coates, Nash and Rowling also fall into this category, as their influence over rankings falls due to new talent rising through the ranks, and their periods in office being considered less significant in the current political context. Likewise, most short-term Prime Ministers additionally fall into this category, with each having not enough time to do something significant that will allow them to be honoured and remembered.

Additionally, the forgettable includes those who are completely forgotten by this survey - namely, those who did not meet the criteria to be considered as part of the rankings (excluding the current Prime Minister). With those excluded from the survey doing so due to never fighting an election or having served less than six months in office, it appears evident that the five Prime Ministers (Bell, Hall-Jones, Mackenzie, Sewell and Waterhouse) omitted from the surveys are almost completely forgotten. In addition to each being a short-term Prime Minister, none managed to produce any notable or memorable moments in office, and largely fail to be remembered. 


\section{Chapter Six: Limitations and future studies}

\section{Limitations}

Naturally, there are a significant number of limitations that must be acknowledged in regard to this research. These limitations can be divided into three different categories - cultural limitations, data limitations and methodological limitations.

\section{Cultural Limitations}

One of the biggest issues that must be addressed when undertaking surveys of this nature is the influence of partisan bias. An increasingly worrying trend in the political realm, scholars are noting the impact that partisan bias is beginning to have. In some cases in the United States, partisan bias has been noted to be becoming stronger than racial bias. ${ }^{203}$ Furthermore, the idea of partisan bias is said to be 'reinforcing our already strong tendency to reflexively dismiss ideas associated with political adversaries. ${ }^{204}$ As a result, people with strong levels of partisan bias are known to pre-emptively reject different political attitudes without giving them any serious consideration on a far more frequent basis than what they once would. ${ }^{205}$

When observing the results of this survey, the influence of partisan bias must be taken into consideration. Whilst no participants were asked to declare their party allegiance or political position on their responses, there is no doubt that some may have struggled to remain objective towards some Prime Ministers whilst grading their performance. One respondent noted the following on their response.

'One issue is one of objectivity but may also be one of culture. For example, I find it difficult as a social democrat/democratic socialist to be objective about Michael Joseph Savage (and, to widen the discussion, I see no conflict between my partisan values and beliefs and my responsibility to the discipline of Political Science).

\footnotetext{
${ }^{203}$ See David Brooks. 2014. 'Why Partyism Is Wrong.' 27 October. The New York Times,

${ }^{204}$ See Ilya Somin. 2015. 'The Disturbing Growth of Partisan Bias.' 9 December. The Washington Post, Washington D.C.

${ }^{205}$ Ibid.
} 
Equally I find it difficult to be objective about Massey, or about Holland given their respective roles in New Zealand Labour History.'

In addition to the concern that potential partisan bias may have on the survey results, there lies an additional issue in regard to the way participants answer a survey. Whilst not as influential on producing skewed results, it must be noted that the researcher had no way of recording what respondents were basing their perceptions of performance on. There was no way to observe whether respondents were basing their perceptions on Prime Ministers that they had experienced, or whether they were primarily basing their rankings of Prime Ministers on what they had read or researched. Such a limitation could have been avoided by asking respondents to only rank those Prime Ministers whose time in office they had personally experienced; however, this would have resulted in no $19^{\text {th }}$ century Premiers or early $20^{\text {th }}$ century Prime Ministers being ranked, hindering the survey results and the purpose of this research. Additionally, there was no way to control the use of electronic devices from participants - an issue that may have had particular influence over the results of the third survey. With the third survey being designed to test recalling Prime Ministers, with no list of those who held office being given to participants, there was no way to tell if respondents were using internet sources to assist their mentions.

A further cultural limitation that needs to be addressed concerns the development of technology over time, and the influence that social media may have over survey results. Particularly in the last decade, social media has increased the transparency between a Prime Minister and the public. Where Prime Ministers were once only seen in newspapers, and eventually evolving to radio and television, they are now extremely accessible to the public on a wide range of various additional platforms, such as Facebook, Twitter, Snapchat and podcasts. Politicians - including Prime Ministers and other political leaders across the globe have become widely known for participating in such platforms, with it becoming common for them to reply to questions on Twitter, to document their days and policy progress, or even to livestream events to their followers. In conjunction, the public have near instant access to news stories on the internet and news streaming sites, as opposed to having to wait for specific newspapers or bulletins at designated times throughout the week. Such instant access allows the public an extra level of accountability unheard of 30 years ago.

Whilst the influence of social media and technology is hard to measure, there lies a possibility that results may be skewed towards favouring those who are exposed to social 
media. Somewhat associated with a recency effect, the modern-day technology platforms allow for greater visibility and transparency and could increase the knowledge that one knows about a Prime Minister. For example, our three most recent Prime Ministers - English, Key and Clark, who each have a high presence on Twitter and directly associate with the public - were more frequently recalled by participants (more so than those recent Prime Ministers who were not exposed to high levels of social media activity). Likewise, the same situation applies to current Prime Minister Jacinda Ardern, who could have an increased level of interest in future studies due to her high impact on social media and her association with 'Jacindamania'. ${ }^{206}$ As social media presence increases over time, it will be interesting to observe whether the earlier serving Prime Ministers fall further off the radar in performance rankings due to their lack of exposure to the public, and whether those who are exposed to social media tend to have higher and more frequent rankings.

\section{Data Limitations}

The forthcoming limitations are directly related to the data that the survey responses produced. In some cases, these limitations are used to explain why these results appeared.

The first limitation towards the survey data that needs to be addressed is the overall lack of responses and lack of interest - particularly for those Premiers and Prime Ministers who held office during the $19^{\text {th }}$ and early $20^{\text {th }}$ centuries. Together both the 2018 survey and the Schlesinger replication produced a similar response rate to the 1998 and 2011 studies, but individually they garnered little interest. The few responses received by these Premiers and Prime Ministers in each survey show the dwindling interest in domestic politics. Furthermore, it illustrates a lack of emphasis in New Zealand on the topic of political history, despite the fact that domestic politics and elections are becoming gradually 'presidentialised'. The political history of New Zealand is slowly being forgotten, and emphasis is no longer being directed to it.

\footnotetext{
${ }^{206}$ Following her takeover as the leader of the New Zealand Labour Party in the lead-up to the 2017 election, and the party surging 19 points in the polls in a month, news outlets began using the term 'Jacindamania', which has been referred to heavily during her first year as Prime Minister in both the domestic and international news and on social media platforms, and has since been regarded as a phenomenon. See Kate Shuttleworth. 2017. “'Jacindamania": Rocketing Rise of New Zealand Labour's Fresh Political Hope.' 2 September. The Guardian: London.
} 
There were very few responses that rated our earlier serving Premiers and Prime Ministers, which can indicate a lack of interest in (and knowledge about) New Zealand political history. This can somewhat be attributed to the lack of accessible knowledge that one can read about all New Zealand Prime Ministers. Whilst there remain a large number of political biographies and autobiographies on former Prime Ministers, and various scholarly assessments of political events and policies, there is lacklustre research on all New Zealand Prime Ministers as a group. For a citizen not well versed in New Zealand's political history, it becomes difficult to gain succinct and concise information, with few non-academic sources available. ${ }^{207}$ Of the few sources that are available, even less are able to provide background for the earlier serving Premiers and Prime Ministers, causing it to become increasingly difficult to gain information outside of the academic sphere. One respondent noted the concern of having little knowledge of said Premiers and Prime Ministers and said the following on their survey.

'For the Political Scientist who is not as well versed in history as she or he might be, how to assess someone of whom they have little knowledge is an issue. Here the 'no response' option is helpful. And perhaps the morally appropriate course is to default to that if one feels that subjectivity is the enemy of a more dispassionate assessment.'

Despite the issues of skewed data results that such a limitation raises, this factor was countered by using a formula to gain a mean result that fairly assessed each Prime Minister, irrespective of the number of responses that each received. However, this limitation still needs to be addressed due to the concern it raises towards New Zealanders' dwindling knowledge of their country's political history.

From an educational perspective, the data produced is further compromised, particularly in the third survey that was conducted. New Zealand lacks a strong civics education programme in both primary and secondary schools, meaning that many students leave school lacking political knowledge and with little understanding of the country's political history. Whilst university allows students to build on the little existing knowledge, it remains limited

\footnotetext{
${ }^{207}$ The Te Ara website provides one of the few easily accessible sources with a biographical entry on all former New Zealand Premiers and Prime Ministers. Additionally, there are few books and resources that biographically assess nearly all former Premiers and Prime Ministers, although the works by Ian Grant and Michael Bassett provide a significant contribution. See McLean, Gavin. 2012. 'Premiers and Prime Ministers.' 20 June. Te Ara: The Encyclopedia of New Zealand.
} 
in what capacity they can do so. Professor Stephen Levine of Victoria University of Wellington previously taught a course in American Politics, that analysed every single President that had held office in the United States. There is no course within New Zealand universities that allows students to learn about every single Premier or Prime Minister that has held office, and instead courses on New Zealand politics tend to focus on specific office holders or policy achievements. In order to best interpret New Zealand history, there needs to be an increased understanding of former office holders. Such a lack of accessibility for both school and university students can contribute to low knowledge rates, and subsequently youth holding little interest in domestic politics. When observing the results of the third survey, such a limitation may be responsible for explaining why data tended to be further skewed towards more recent Prime Ministers as opposed to earlier ones.

\section{Methodological Limitations}

The final category of limitations that need to be addressed are the ones that directly concern the methodology and samples of this research. With the methodology playing a crucial part in producing valid results, measures were taken to ensure the methods chosen were able to do this. However, in some cases, there are issues related to the methodology that were unavoidable for these particular surveys and must be taken into account.

Respondents noted the concern of ranking Prime Ministers under the chosen methodology and questioned that the methods did not necessarily take some situations into account. For example, one respondent questioned how to rank Prime Ministers who served in office more than once over non-consecutive periods - a common occurrence with earlier serving Premiers and Prime Ministers. The case of Joseph Ward provides an example. Ward initially served from 1906-1912 under the Liberal Party and returned to office in 1928 as leader of the United Party. Whilst his first occasion in office was deemed somewhat successful, his subsequent return to office was considered a failure. The methodology did not allow for respondents to rank each period in office separately, and instead required them to rank his performance as a whole. Whilst this was easily overcome, it may have skewed the rankings of some Prime Ministers to being better or worse than what they should have been, as respondents may have only focused on one period in office. 
A subsequent issue following on from Prime Ministers having multiple stints in office, and raised multiple times by respondents, concerns those who had other significant roles in parliament outside of being Prime Minister. Many noted that Prime Ministers such as Marshall, Grey and Palmer all had significant careers as cabinet ministers or in other posts but were mediocre Prime Ministers at best. Subsequently, one respondent noted concern over the perception of Peter Fraser being changed due to his highly successful and transformational period as Minister of Education. Although the surveys explicitly asked respondents to comment on the time one held in the top job, there was no way to control whether perceptions were altered by former or future roles that a Prime Minister may have had.

A small range of possible sampling issues were identified, although none have had any significant impact on the results of any surveys. Firstly, it should be noted that this research sought to achieve as balanced a sample as possible, with an even distribution between males and females. However, due to an imbalance in the political science profession towards males, the initial sample of 139 potential participants had more males, with 86 being invited to complete a response. ${ }^{208}$ Due to the issue of anonymity in the return of the surveys, it was difficult to determine whether the responses were balanced in terms of gender.

Whilst having a gender balance is not a necessity when conducting surveys of this nature, it needs to be considered as to whether it could have an influence over results. As previously identified, such a trend was witnessed in the United Kingdom, with the Theakston and Gill survey noting that females tended to rank Margaret Thatcher more highly than Atlee or Churchill. ${ }^{209}$ One must consider the possibility of female Prime Ministers emerging higher in the results if the female participants outweighed their male counterparts in the studies. Whilst New Zealand has only had three female Prime Ministers, both were of recent times and may have had a higher position in rankings if only female participants were involved.

An additional sampling issue concerns the third survey that was conducted. With the survey designed to test three different university levels of study over three different courses, it must be noted that there was no control over who was included in these courses. In some cases, classes had a small sample of mature students - often older adults returning to university study

\footnotetext{
208 See Danielle Kurtzleben. 2016. 'Why Aren't There More Women In Politics?'. 11 June. National Public Radio: Washington D.C. and Sidney Verba, Nancy Burns, and Kay Lehman Schlozman. 1997. 'Knowing and Caring About Politics: Gender and Political Engagement.' The Journal of Politics 59 (4). P. 1051.

${ }^{209}$ See Kevin Theakston and Mark Gill. 'Rating 20 2 -Century British Prime Ministers.' p. 199.
} 
- or students in courses above or below their actual year level. However, with such students being limited in numbers in the overall sample, this limitation would have had very little influence over the overall final results.

\section{Future Studies}

With scholarship in this field lacking on both a domestic and international scale, it remains important that further research is undertaken in order to persist and expand on the already existing literature. There are various paths that this research can take in future studies, in ways that will support and enhance the exploration of New Zealand's political history.

The entrance of Jacinda Ardern in a later set of rankings will provide an interesting analysis. As New Zealand's third female Prime Minister, it will be interesting to observe her place in future rankings, particularly following her shock rise to power. Additionally, with her government rapidly designing and implementing new policy in the modern day economy to support areas such as social welfare, housing, health and education -something that was somewhat limited under the Fifth National Government - it will be alluring to see whether she enters into the category of being a 'big change' Prime Minister. Regardless of whether Ardern manages to make a somewhat transformational impact on domestic politics, she will provide a curious case for scholars to observe in regard to her unexpected alteration of the Labour Party in the 2017 general election, leading it to grow in support, surge in the polls and become a viable contender for government - something Labour had been unable to do for the previous nine years.

Further research can take different forms, and an intriguing way to expand on the literature is to investigate some of the limitations that have been identified in this study. With the limitations allowing multiple avenues of areas to research, they provide a unique way of assessing Prime Ministerial performance. For example, further research could be conducted with more control over variables associated with participants, such as age, occupation, political preference or gender. Research in New Zealand has already shown that during the 2005 election, women were more likely to vote for a Labour Party led by Helen Clark than they were for a male candidate. ${ }^{210}$ A survey with specific variables controlling the gender of participants

${ }^{210}$ See Jennifer Curtin. 2018. 'Introduction'. In Helen Clark. Women, Equality, Power. p. 17-18. 
could build upon this research, and investigate how women or men tend to rank the performance of Prime Ministers, and whether specific trends appear within the results.

Subsequently, questions were raised by participants who took part in this research as to where the list of Prime Ministers assessed should be commencing from. As seen in other nations across the world, surveys have been conducted that assess political leaders across different time periods, whether it be of the last fifty years, or those leaders that served before or after specific wars. In New Zealand this has never been investigated, and the growing realm of political leadership allows a future researcher to assess Prime Ministers from a specific time frame, such as those who have served under the title of Prime Minister, or those who served during the $19^{\text {th }}$ century. An expansion into such a subfield of leadership assessment could allow for further ways of assessing Prime Ministerial performance.

The scope of this research allows for multiple pathways to be pursued by future researchers and scholars. Expanding on the existing literature will only continue to develop knowledge regarding the public perceptions of Prime Ministerial performance, and will allow future generations to benefit from such research. In conjunction with understanding the field of political leadership in New Zealand more so than at present, the expansion of this area of research can enhance our understanding of our political history and will continue to develop New Zealand's place in the game of ranking political leaders. 


\section{Chapter Seven: Conclusion}

This thesis has served to garner a further understanding of political performance and leadership in New Zealand. Through a series of surveys, this thesis has been able to analyse and discuss the performance of former Premiers and Prime Ministers, identifying those who fulfil the components associated with a great leader, and those who do not. Complementing the ranking exercises conducted in 1998 by Simon Sheppard, and again in 2011 by Jon Johansson and Stephen Levine, this thesis has allowed for further insight into performance in the top office, and has provided an enhanced understanding of political leadership in New Zealand.

By undertaking this research, this thesis has also allowed individuals (with a professional interest in New Zealand politics and history) to think about former Premiers and Prime Ministers in a different way, and to determine what they believe distinguishes exceptional leadership from the more lacklustre and ordinary. This research has shown what individuals identify as the various leadership dimensions correlated with successful political performance. Whilst such dimensions may not necessarily embody successful political leadership on a global scale, it identifies the qualities that New Zealanders prize in their Premiers and Prime Ministers.

The findings of this thesis have been clear and consistent across the series of surveys that were conducted. The performance of Michael J. Savage, Richard Seddon, Helen Clark and Peter Fraser can be observed to best reflect upon what New Zealanders perceive to be successful political leadership. Each of these Prime Ministers has been perceived to embody the highest calibre of successful leadership in New Zealand. With few changes in the public perception of each leader over the past two decades, each provides the benchmark for outstanding political leadership, successfully meeting the criteria associated with it, which has been identified throughout chapters two and five of this thesis.

This research was also conducted with a set of aims to best expand upon this field of political leadership. Alongside executing a series of viable surveys to provide a current list of rankings of former office holders, this thesis has used various aims to best approach this 
research. The subset of these aims was to explore if specific variables play a role in influencing the results of each ranking study: namely the role that time plays (and if an appearance of a recency effect appears evident), and whether different sets of methodology provide different results. In both cases, this thesis has identified that each variable has proven to have had little influence over ranking results. Differences in results over time have proven to have had little variation, with perceptions changing only slightly. Whilst a recency effect was somewhat identified through the third survey, it has proven to have had miniscule influence over the results of the 2018 survey and the Schlesinger replication. Subsequently, this thesis has identified that there are few differences that arise from different methodologies, with each survey that was conducted aligning closely to each other despite such factors. Each survey allows a different pathway for this research to be continued upon, all whilst still contributing towards overall perceptions of Prime Ministerial performance in New Zealand.

As noted in the introduction of this thesis, research of this sub-field of political leadership proves limited, and is thinly conducted in New Zealand. Thus, this research aimed to further explore the history of political performance in New Zealand, and promote the expansion in a sparse field of literature. Further research in this area of political leadership in New Zealand is important, and will allow for future generations to gain an enhanced understanding of political performance, as well as contribute towards a path-dependency that allows future scholars to compare New Zealand Premiers and Prime Ministers with earlier data.

It should be noted, much as in both the 1998 and 2011 surveys, that these results are transferable; rather than providing an overall consensus of the performance of Premiers and Prime Ministers, the findings of this thesis provide a snapshot of the political context at the present time. By contributing towards the path-dependency established by Simon Sheppard, and built upon by Jon Johansson and Stephen Levine, this research provides a glimpse towards the continuation of assessment by future generations. As it stands, the dimensions that the political and academic elite believe to be linked to elevated reputation have remained near identical over the past two decades. However, with the ever changing context of politics in New Zealand, the next survey conducted may provide an entirely different snapshot, and may see those regarded as great leaders fall further down the ladder as newer Prime Ministers enter the rankings. As reforms, policies, and transformational periods are assessed by a different generation with different values to those in the earlier exercises, future surveys could see a vastly different set of results. Further exercises, in perhaps 10 to 15 years, may see participants 
refer to other variables and qualities that they believe best embody successful political leadership, providing a further glimpse into how the performance of New Zealand Premiers and Prime Ministers might be best assessed. 


\section{Appendices}

Appendix 1: Information Sheet for Participants (Survey 1)

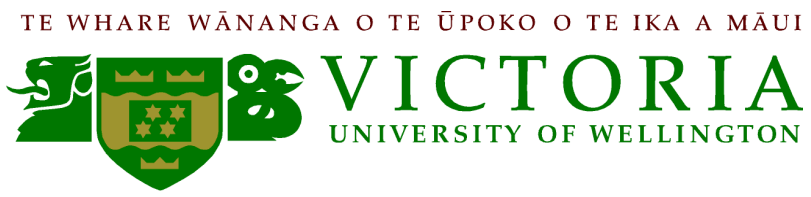

\section{The first-class, the familiar and the forgettable: Exploring Prime \\ Ministerial performance in New Zealand}

Dear

In 1998, and again in 2011, political scientists Simon Sheppard, Jon Johansson and Stephen Levine surveyed historians, political scientists, journalists and former Members of Parliament to produce a ranking of New Zealand's prime ministers. These much-cited surveys are now being carried out for the third time. In addition to being reported in New Zealand, the results of this study will be published as part of a Master of Arts degree in Political Science at Victoria University of Wellington.

While assessing the performance of prime ministers is inevitably somewhat subjective, these studies provide opportunities to reassess (and compare) political leadership, while observing changes over time in perceptions about political leadership and the accomplishments in office of a nation's top political figures.

I am inviting a group with particular interests in New Zealand history, politics and political leadership to take part in this new study. I hope that you will be able to participate and to share your perceptions, in the hopes of providing a valuable contribution towards the research of my thesis.

As you will see, the survey is not very time-consuming and should take no longer than approximately 30 minutes to complete.

The first part asks respondents to give each of the listed Prime Ministers in the attached Table a rank from 0 to 10 in the five categories beside their name. The five categories are:

- Leadership Qualities - how effective the Prime Minister was in motivating and inspiring the nation, bringing the people behind a legislative agenda, and winning an election.

- Parliamentary Skills - how effective the Prime Minister was in maintaining a parliamentary majority, dominating the opposition in parliament, setting the agenda in debate and 'question time', and managing news media coverage. 
- Party Management - how effective the Prime Minister was in maintaining unity and purpose in their parliamentary caucus and cabinet, handling caucus dissent, and managing their relationship with the wider party organisation.

- Crisis Management - how effective the Prime Minister was in responding to unexpected developments (economic, political, military, natural disaster, and so on).

- Legislative Achievements - an assessment of the legacy for which the Prime Minister is responsible: the extent to which their term in office was a catalyst for positive change in New Zealand politics, economy and society.

The second part of the survey asks for an overall appraisal of the performance of each Prime Minister according to one of the following five options:
A) Outstanding
B) Above Average
C) Average
D) Below Average
E) Failure

The premiers and prime ministers covered in this survey include only those who held office for more than six months or who fought a general election while in office. The incumbent prime minister has also been excluded from this survey (as Jenny Shipley was excluded from Sheppard's 1998 study and John Key from the 2011 assessment).

It is appreciated that many of New Zealand's earlier prime ministers remain fairly obscure figures. In completing the survey, please feel free to leave category and rating boxes blank for those premiers and prime ministers about whom you feel unable to offer an assessment. Similarly, premiers and prime ministers can be given rankings in some of the categories (e.g., 'leadership qualities') even when you feel unable to do so for other categories (e.g., 'crisis management').

Finally, the survey offers an opportunity for you to suggest the name of a person whom you feel would have been a fine prime minister - 'the best Prime Minister New Zealand never had': any individual, not necessarily a politician, who never served in the office but whom you feel might well have made a significant positive contribution in the role had that individual done so.

As noted, the results of the survey are intended to be published as part of a thesis, and may also be used in future conference presentations and publications. Your contribution can be made strictly anonymous if you so wish. If you have no objections to being quoted, however, there is space in the survey for you offer particular comments on your choice of New Zealand's 'top' Prime Minister, and your comments may be published in the study. However, if you wish to remain anonymous whilst completing this survey, you may do so by returning your response by post to address given below in the next paragraph, and ignoring the comments section so your response is unidentifiable. (Please note that if you chose to submit your survey anonymously, your response will be unable to be withdrawn from this study.) For those that consent to having their responses quoted, a consent form has been attached, and must be returned with your final response. Non-confidential submissions can either be returned by email or post (and are able to be withdrawn if you so wish). If you wish for your response to 
be withdrawn for any reason, please inform the researcher at the below contact details by $\mathbf{3 1}^{\text {st }}$ March, 2018. All responses gathered for this research will be destroyed following the completion of this thesis, on 1 September 2018.

Please return your completed responses either via email (for non-confidential respondents), or by post to Kate Smith, c/- Professor Stephen Levine, School of History, Philosophy, Political Science and International Relations, Victoria University of Wellington, (P.O. Box 600, Wellington 6140, New Zealand). Responses are required to be returned 15 March, 2018. by If you would like a copy of the results of the study when published, please indicate this on your consent form and a copy will be sent to you.

Any questions regarding this research can be directed to either myself or my supervisor. If you have any concerns about the ethical conduct of the research you may contact the Victoria University HEC Convenor Associate Professor Susan Corbett, at susan.corbett@vuw.ac.nz or telephone +64-4-463 5480 .

\section{Student:}

Name: Kate Smith

kate.smith@vuw.ac.nz

\section{Supervisor:}

Name: Professor Stephen Levine

School of History, Philosophy, Political Science and International Relations

Phone: 044636099

stephen.levine@vuw.ac.nz

Thank you very much for contributing to what I believe will be a useful and thought-provoking discussion about trends in leadership and prime ministerial performance in New Zealand, and providing valuable insight towards this research

Kate Smith

Victoria University of Wellington 


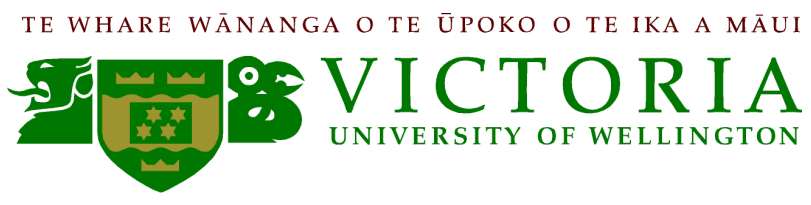

\section{The first-class, the familiar, and the forgettable: Exploring Prime-Ministerial performance in New Zealand}

\section{CONSENT TO SURVEY}

This consent form will be held for 1 year.

Researcher: Kate Smith, School of History, Philosophy, Political Science and International Relations, Victoria University of Wellington.

- I have read the attached letter and the project has been explained to me. My questions have been answered to my satisfaction. I understand that I can ask further questions at any time.

- I agree to take part in a survey.

I understand that:

- I may withdraw from this study at any point before 31 March 2018, and any information that I have provided will be returned to me or destroyed.

- $\quad$ The identifiable information I have provided will be destroyed on 1 September 2018

- Any information I provide will be kept confidential to the researcher and the supervisor, Professor Stephen Levine.

- I understand that the results will be used for a Masters of Arts thesis and academic publications.

- I consent to information or opinions which I have given being attributed to me in any reports on this research:

Yes $\square \quad$ No

- $\quad$ I would like to receive a copy of the final report and have added my email

Yes $\square \quad$ No address below.

Signature of participant:

Name of participant:

Date:

Contact details: 
Appendix 2: Survey 1: Replication of Sheppard (1997), and Johansson and Levine (2011)

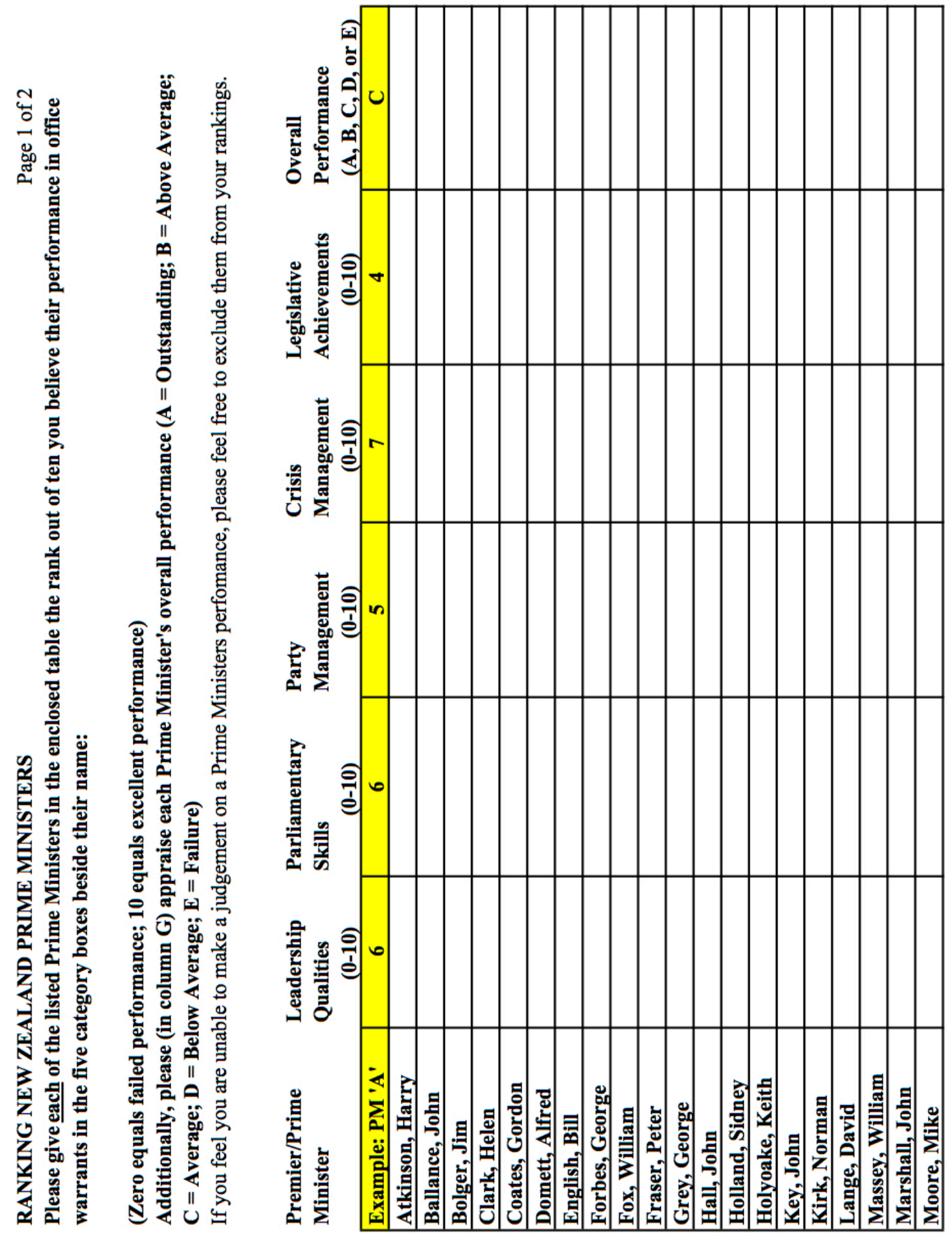




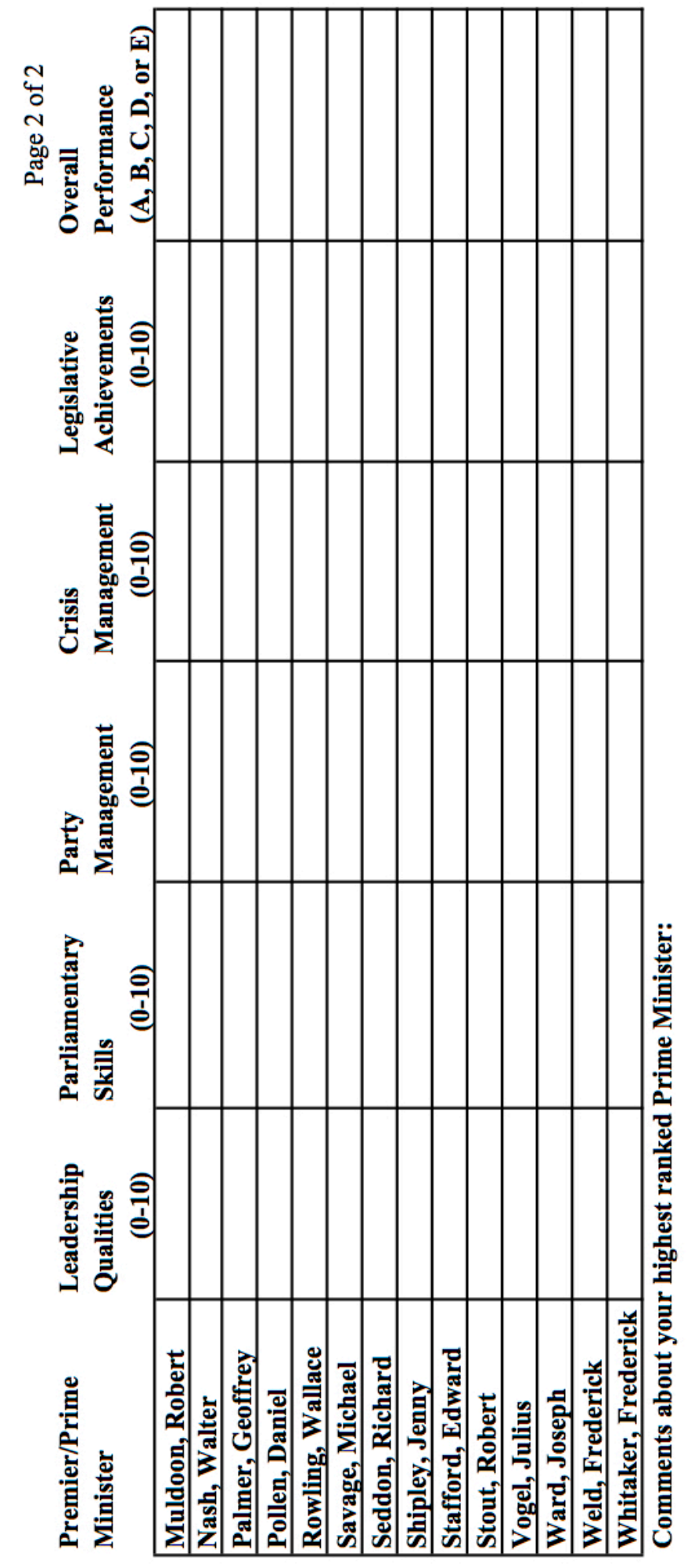

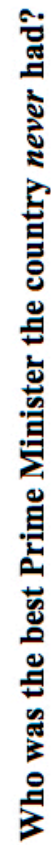




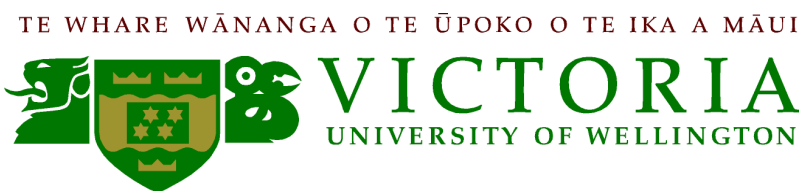

\section{The first-class, the familiar and the forgettable: Exploring Prime Ministerial performance in New Zealand}

Dear

In 1948, 1962, and again in 1997, a series of surveys were conducted in the USA by historian Arthur Schlesinger (1948, 1962), and by his son, Arthur Schlesinger Jr. (1997). The surveys were designed to produce a comprehensive ranking of American Presidents and have been cited since their completion. These surveys, believed to be the first of their kind, have been replicated across the world.

Whilst previous studies ranking Prime Ministers have been conducted in New Zealand in the past, none have ever taken on the methodology and analysis used in the Schlesinger surveys. Therefore, this survey is being conducted for the first time in New Zealand. In addition to being reported in New Zealand, the results of this study will be published as part of a Master of Arts degree in Political Science at Victoria University of Wellington.

While assessing the performance of prime ministers is inevitably somewhat subjective, these studies provide opportunities to reassess (and compare) political leadership, while observing changes over time in perceptions about political leadership and the accomplishments in office of a nation's top political figures.

I am inviting a group with particular interests in New Zealand history, politics and political leadership to take part in this new study. I hope that you will be able to participate and to share your perceptions, in the hopes of providing a valuable contribution towards the research of my thesis.

As you will see, the survey is not very time-consuming, and should take no longer than approximately 30 minutes to complete.

The survey is very simple and asks respondents to rank former Prime Ministers on a five-fold scale- Great, Near-Great, Average, Below Average and Failure. Respondents may rank each Prime Minster in terms of how they best view their time in office.

The premiers and prime ministers covered in this survey include only those who held office for more than six months $o r$ who fought a general election while in office. The incumbent prime minister has also been excluded from this survey.

It is appreciated that many of New Zealand's earlier prime ministers remain fairly obscure figures. In completing the survey, please feel free to leave boxes blank for those premiers and prime ministers about whom you feel unable to offer an assessment. 
As noted, the results of the survey are intended to be published as part of a thesis, and may also be used in future conference presentations and publications. Your contribution can be made strictly anonymous if you so wish. If you have no objections to being quoted, however, there is space in the survey for you offer particular comments on your choice of New Zealand's 'top' prime minister, and your comments may be published in the study. However, if you wish to remain anonymous whilst completing this survey, you may do so by returning your response by post to address given below in the next paragraph, and ignoring the comments section so your response is unidentifiable. (Please note that if you chose to submit your survey anonymously, your response will be unable to be withdrawn from this study.) For those that consent to having their responses quoted, a consent form has been attached, and must be returned with your final response. Non-confidential submissions can either be returned by email or post (and are able to be withdrawn if you so wish). If you wish for your response to be withdrawn for any reason, please inform the researcher at the below contact details by $\mathbf{3 1}$ March 2018. All responses gathered for this research will be destroyed following the completion of this thesis, on 1 September 2018.

Please return your completed responses either via email (for non-confidential respondents), or by post to Kate Smith, c/- Professor Stephen Levine, School of History, Philosophy, Political Science and International Relations, Victoria University of Wellington, (P.O. Box 600, Wellington 6140, New Zealand). Responses are required to be returned 15 March 2018. by If you would like a copy of the results of the study when published, please indicate this on your consent form and a copy will be sent to you.

Any questions regarding this research can be directed either to myself or my supervisor. If you have any concerns about the ethical conduct of the research you may contact the Victoria University HEC Convenor Associate Professor Susan Corbett at susan.corbett@vuw.ac.nz or telephone +64-4-463 5480 .

\section{Student:}

Name: Kate Smith

kate.smith@vuw.ac.nz

\section{Supervisor:}

Name: Professor Stephen Levine

School of History, Philosophy, Political

Science and International Relations

Phone: 044636099

stephen.levine@vuw.ac.nz

Thank you very much for contributing to what I believe will be a useful and thought-provoking discussion about trends in leadership and prime ministerial performance in New Zealand, and providing valuable insight towards this research.

Kate Smith

Victoria University of Wellington 


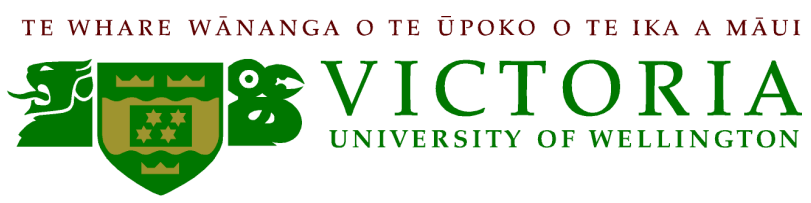

\section{The first-class, the familiar, and the forgettable: Exploring Prime-Ministerial performance in New Zealand}

\section{CONSENT TO SURVEY}

This consent form will be held for 1 year.

Researcher: Kate Smith, School of History, Philosophy, Political Science and International Relations, Victoria University of Wellington.

- I have read the attached letter and the project has been explained to me. My questions have been answered to my satisfaction. I understand that I can ask further questions at any time.

- $\quad$ I agree to take part in a survey.

I understand that:

- I may withdraw from this study at any point before 31 March 2018, and any information that I have provided will be returned to me or destroyed.

- $\quad$ The identifiable information I have provided will be destroyed on 1 September 2018

- Any information I provide will be kept confidential to the researcher and the supervisor, Professor Stephen Levine.

- I understand that the results will be used for a Masters of Arts thesis and academic publications.

- I consent to information or opinions which I have given being attributed to me in any reports on this research:

Yes $\square \quad$ No

I would like to receive a copy of the final report and have added my email

Yes $\square \quad$ No address below.

Signature of participant:

Name of participant:

Date:

Contact details: 
Appendix 4: Survey 2: Replication of Schlesinger methods

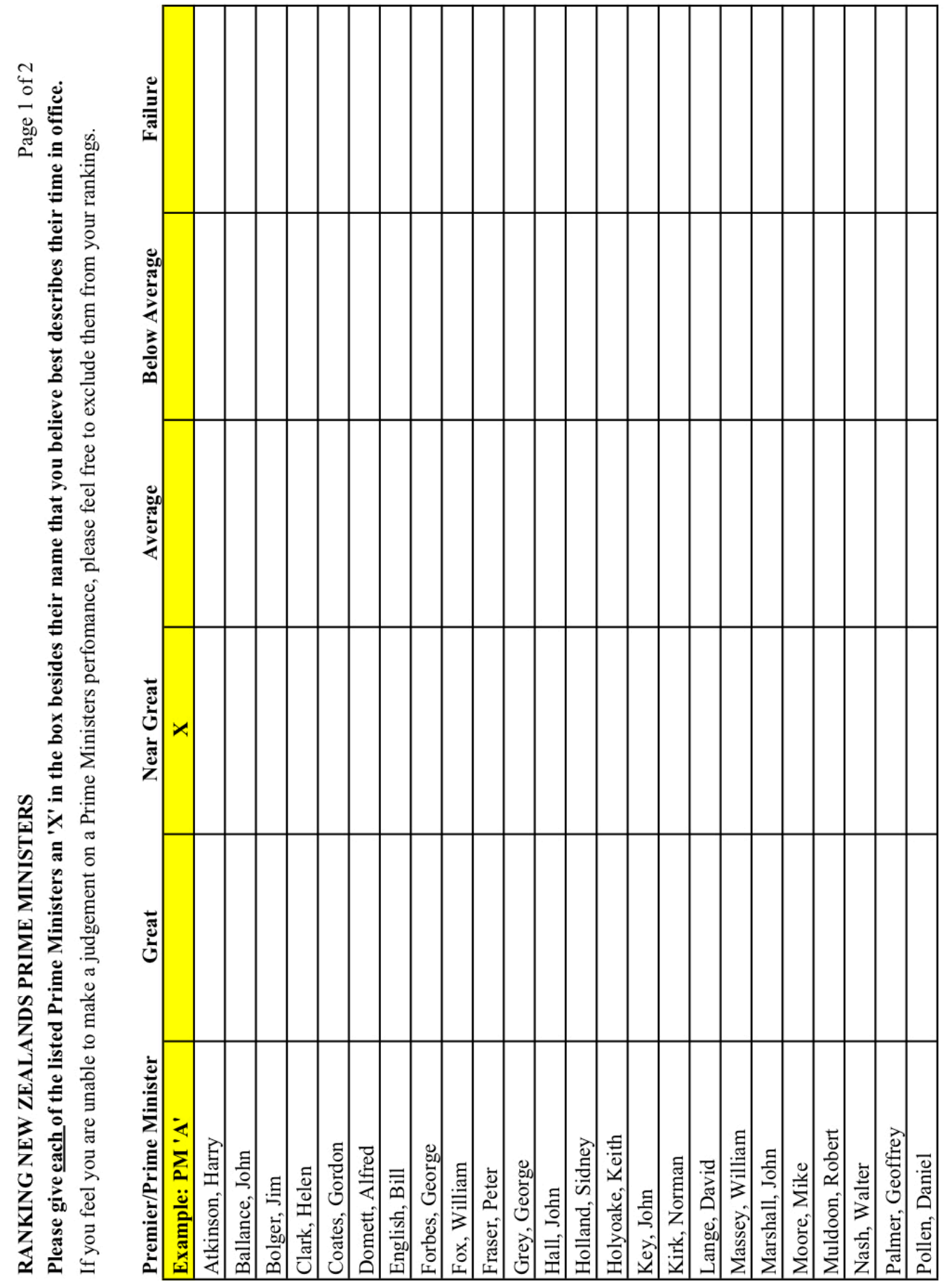




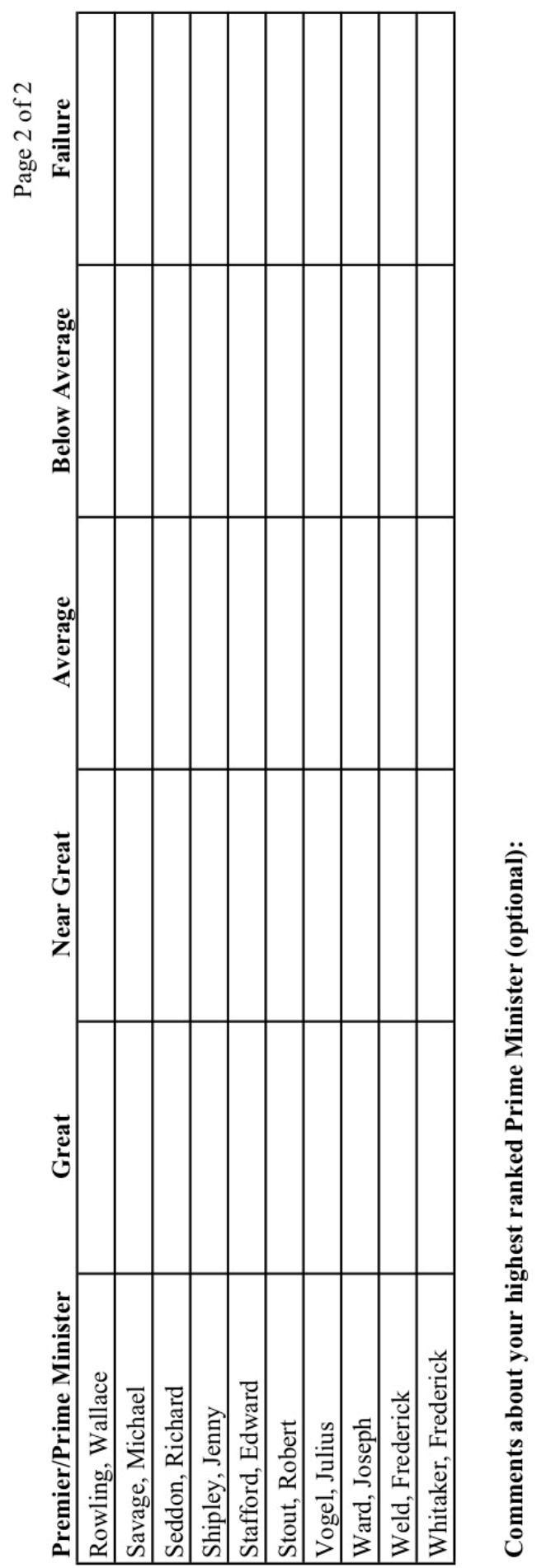


TE WHARE WĀNANGA O TE ŪPOKO O TE IKA A MĀUI

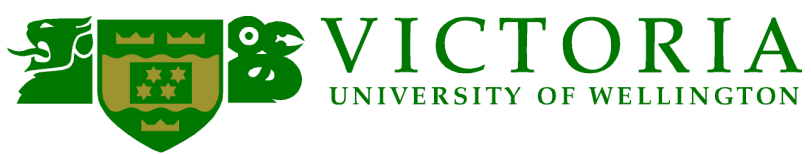

\section{The first-class, the familiar and the forgettable: Exploring Prime Ministerial performance in New Zealand}

This research has been approved by the Human Ethics Committee of Victoria University of Wellington as part of a Master of Arts degree in Political Science (0000025351). Please note that due to anonymity, once your survey has been received it will be unable to be withdrawn. If you do not wish to participate in this research, please do not complete a survey.

Please answer the following questions to the best of your ability. Please note that the questions are related to all of New Zealand's Premiers (19 $9^{\text {th }}$ century) and Prime Ministers $\left(20^{\text {th }}-21^{\text {st }}\right.$ century) EXCLUDING the current Prime Minister.

1.) Who do you believe to be the best Prime Minister (or Premier) New Zealand has ever had?

2.) Who do you believe to be the worst Prime Minister (or Premier) New Zealand has ever had?

3.) Please give a reason for your choice of best and worst Prime Ministers (or Premiers) Best:

Worst: 
Copies of the surveys were sent to the following groups and people:

Jim McAloon

Kate Hunter

Arini Loader

Adrian Muckle

Fiona Barker

David Capie

Van Jackson

Warren Feek

Kate Schick

Jack Vowles

Jonathan Boston

Matthew Nicoll

Dolores Janiewski

Cybele Locke

Valerie Wallace

Alexander Bukh

Xiaoming Huang

Stephen Levine

Greta Snyder

Nigel Roberts

Michael Bassett

Anna Bracewell-Worrall

Nick Perry

Henry Cooke

Ripeka Timutimu

Grant Walker

John E Martin

Brent Edwards

Katrina Bennett

Claire Trevett

Peter Wilson

Chris Bramwell

Gyles Beckford

Patrick O’Meara

Whena Owen

Corin Dann

Katie Bradford

Andrea Vance

Mark Boyd

Thomas Gregory

Anita Lacey

Stephen Noakes

Stephen Winter

Priya Kurian

Mike Hosking

William Harris
Sekhar Bandyopadhyay

Rebecca Lenihan

Charlotte Macdonald

Hilde Coffe

Margaret Clark

Jon Fraenkel

Xavier Marquez

Kate McMillan

Ben Thirkell-White

Chris Eichbaum

Catherine Abou-Nemeh

Steve Behrendt

Giacomo Lichtner

Alexander Maxwell

Robert Ayson

Giacomo Chiozza

Jon Johansson

Manjeet Pardesi

Jason Young

Neill Atkinson

Patrick Gower

Dene Mackenzie

Tracy Watkins

Stacey Kirk

Rob Hosking

Jenny Ruth

Gavin McLean

Barry Soper

Audrey Young

Fran O'Sullivan

Kris Dando

Jane Patterson

Kathryn Ryan

Guyon Espiner

Katie Stevenson

Jessica Roden

Anna Harcourt

Joe Atkinson

Gerard Cotterell

Stephen Hoadley

Julie MacArthur

Martin Wilkinson

Joe Burton

Dan Zirker

Brad Jackson

Nicholas Khoo 
Phillip Nel

Lena Tan

Amy Fletcher

Lea Kortman

Bronwyn Hayward

Grant Duncan

Maria Armoudian

Jennifer Curtin

Jennifer Lees-Marshment

Katherine Smits

Patrick Barrett

Geoffrey Cupit

Brodie Fraser

Joshua James

Carla Lam

Chris Rudd

Anne-Marie Brady

James Ockey

Richard Shaw

Bethan Greene

Claire Timperley

Peter Cozens

Ian Grant

Jane Clifton
Brian Roper

Alex Tan

Lindsey MacDonald

Mark Francis

Toby Boraman

Nigel Parsons

Gerald Chan

Geoff Kemp

Raymond Miller

Chris Wilson

Colm McKeogh

Reuben Steff

Janine Hayward

James Headly

Robert Patman

Jim Flynn

Jeremy Moses

Pascale Hatcher

Emily Beausoleil

Robin Peace

Simon Smith

Malcolm McKinnon

Simon Sheppard

Members of the Association of Former Members of Parliament

Students of Pols 111: Introduction to New Zealand Government and Politics

Students of Pols 353: Growing Pains: New Zealand Politics from 1975 to Present

Students of Pols 428: Directed Individual Study: Parliamentary Internship 
13 February 2018

Dear ......

My name is Kate Smith and I am a postgraduate student at Victoria University of Wellington. I am currently undertaking my Master of Arts (by thesis) in Political Science under the supervision of Professor Stephen Levine.

My research looks at political leadership, and in particular focuses on Prime Ministerial performance in New Zealand. As part of my thesis, I am undertaking a series of surveys that are designed to produce a ranking of New Zealand's former Prime Ministers and Premiers in terms of their performance in office. Research of this kind has been previously conducted in 1998 by Simon Sheppard, and again in 2011 by Jon Johansson and Stephen Levine. These studies, in turn, were inspired by the surveys conducted in the United States by historians Arthur Schlesinger $(1948,1962)$ and his son, Arthur Schlesinger Jr. (1997). An interest in what makes for successful leadership - presidential or prime ministerial - unites these studies, giving them ongoing international interest and relevance.

I am writing today to invite you to take part in this research, and to complete a survey ranking Prime Ministerial performance in New Zealand. I have attached both the questionnaire and brief instructions to this email, and I would appreciate your participation by returning a completed response.

Many thanks. I look forward to hearing from you in due course.

Kind regards,

Kate Smith 


\author{
Bessie Sutherland \\ Association of the Former Members of Parliament \\ Parliament Buildings \\ Wellington, New Zealand
}

13 February 2018

Dear Bessie,

My name is Kate Smith and I am a postgraduate student at Victoria University of Wellington. I am currently undertaking my Master of Arts (by thesis) in Political Science under the supervision of Professor Stephen Levine.

My research looks at political leadership, and in particular focuses on Prime Ministerial performance in New Zealand. As part of my thesis, I am undertaking a series of surveys that are designed to produce a ranking of New Zealand's former Prime Ministers and Premiers in terms of their performance in office. Research of this kind has been previously conducted in 1998 by Simon Sheppard, and again in 2011 by Jon Johansson and Stephen Levine. These studies, in turn, were inspired by the surveys conducted in the United States by historians Arthur Schlesinger $(1948,1962)$ and his son, Arthur Schlesinger Jr. (1997). An interest in what makes for successful leadership - presidential or prime ministerial - unites these studies, giving them ongoing international interest and relevance.

I am writing to you today to ask if you would be able to assist, so that former MPs - members of the Association of Former Members of Parliament - have the opportunity to participate in this research. Participants will be asked to complete a survey inviting them to rank the performance of former Prime Ministers. That should take no longer than 30 minutes to complete. Participants may remain anonymous if they wish. The research has been approved by the Victoria University Human Ethics Committee.

If you are able to assist, I would greatly appreciate my surveys being distributed to the members of the Association of Former Members of Parliament. This can be distributed digitally - I can send you the questionnaire and the brief instructions that accompany it - or if you prefer I am happy to distribute these materials by any other means you may suggest.

If you have any questions regarding this request or my research, you can either contact me directly or you can contact my supervisor Professor Stephen Levine at: stephen.levine@vuw.ac.nz

Many thanks. I look forward to hearing from you in due course.

Kind regards,

Kate Smith 


\section{Bibliography}

Abjorensen, Norman. 1992. 'Australia's Top 10 PM's.' 5 December. Canberra Times. 1921.

Anderton, Jim. 2001. 'Kirk and Rowling: Recollections and Significance.' In Margaret Clark (ed). Three Labour Leaders. Palmerston North: Dunmore. 50-58.

Balz, John. 2010. 'Ready to Lead on Day One: Predicting Presidential Greatness from Political Experience.' Political Science and Politics 43 (3): 487-92.

Barnes, Steven. 2009. 'What About Me? Deputy Prime Ministership in New Zealand.' Political Science. 61 (1): 33-49.

Bartels, Larry M. 2002. 'Beyond the Running Tally: Partisan Bias in Political Perceptions.' Political Behavior 24 (2): 117-50.

Bassett, Michael. 2017. New Zealand's Prime Ministers: From Dick Seddon to John Key. Mangawhai: David Ling Publishing.

Bassett, Michael, and Michael King. 2000. Tomorrow Comes the Song: A Life of Peter Fraser. Auckland: Penguin.

Bell, David S. 2014. 'Political Leadership.' Government and Opposition. 49 (1): 139-58.

Bennister, Mark, Paul 't Hart and Ben Worthy. 2014. 'Assessing the Authority of Political Office-Holders: The Leadership Capital Index.' West European Politics. 38 (3). Routledge: 417-40.

Braungart, Richard G, and Margaret M. Braungart. 1986. 'Life-Course and Generational Politics.' Annual Review of Sociology. Vol. 12. 205-231.

Brinkley, Douglas G., Edna Greene Medford and Richard Norton Smith. 2017. 'C-SPAN Survey on Presidents 2017.' C-Span.

https://www.c-span.org/presidentsurvey2017/?page=overall.

Brooks, David. 2014. 'Why Partyism Is Wrong.' 27 October. The New York Times.

Clark, Helen. 2018. Women, Equality, Power. Auckland: Allen \& Unwin.

Clark, Margaret (ed). 1997. Sir Keith Holyoake: Towards a Political Biography. Palmerston North: Dunmore.

- (ed). 1998. Peter Fraser: Master Politician. Palmerston North: Dunmore.

— (ed). 2001. Three Labour Leaders. Palmerston North: Dunmore.

— (ed). 2004. Muldoon Revisited. Palmerston North: Dunmore. 
- (ed). 2005. For the Record: Lange and the Fourth Labour Government. Wellington: Dunmore.

— (ed). 2008. The Bolger Years: 1990-1997. Wellington: Dunmore.

Conger, J. A. and R. N. Kanungo. 1987. 'Toward a Behavioural Theory of Charismatic Leadership in Organizational Settings.' Academy of Management Review. 12 (4): 63747.

Colman, Andrew M. 2009. A Dictionary of Psychology. Oxford: Oxford University Press.

Coolidge, Calvin. 1929. Autobiography of Calvin Coolidge. London: Chatto and Windus.

Cunningham, Stuart. 2008. 'Political and Media Leadership in the Age of YouTube.' In t'Hart, Paul and John Uhr, (eds). Public Leadership: Perspectives and Practices. Canberra: ANU Press. 177-186.

Curry, Jill L. and Irwin L Morris. 2008. 'The Contemporary Presidency: Explaining Presidential Greatness: The Roles of Peace and Prosperity?'. Presidential Studies Quarterly: Presidential Election, Part II. 40 (3): 515-30.

Curtin, Jennifer. 2008. 'Women, Political Leadership and Substantive Representation: The Case of New Zealand.' Parliamentary Affairs. 61 (3): 490-504.

- 2008. 'Comparing Pathways to Power: Women and Political Leadership in New Zealand.' In t'Hart, Paul and John Uhr, (eds). Public Leadership: Perspectives and Practices. Canberra: ANU Press. 265-274.

— 2018. 'Introduction'. In Helen Clark. Women, Equality, Power. Auckland: Allen \& Unwin. 13-20.

Dalton, Russell J. 2008. Citizen Politics: Public Opinion and Political Parties in Advanced Industrial Democracies. 5th ed. Washington D.C: CQ Press.

Deese, James and Roger A. Kaufman. 1957. 'Serial Effects in Recall of Unorganized and Sequentially Organized Verbal Material.' Journal of Experimental Psychology. 54 (3).

Denver, David, and Gordon Hands. 1990. 'Does Studying Politics Make a Difference? The Political Knowledge, Attitudes and Perceptions of School Students.' British Journal of Political Science 20 (2): 263-79.

Dion, Léon. 1968. 'The Concept of Political Leadership: An Analysis.' Canadian Journal of Political Science 1 (1): 2-17.

Doughty, Ross A. 1977. The Holyoake Years. Feilding: Barry Hickman.

Dowding, Keith. 2008. 'Perceptions of Leadership.' In t'Hart, Paul and John Uhr, (eds). Public Leadership: Perspectives and Practices. Canberra: ANU Press. 
Eagles, Jim and Colin James. 1973. The Making of a New Zealand Prime Minister. Wellington: Cheshire Publishing.

Ebbinghaus, Hermann. 2013. 'Memory: A Contribution to Experimental Psychology.' Annals of Neurosciences. 20. (4). 155-156.

Felzenberg, Alvin S. 1997. 'There You Go Again: Liberal Historians and The NY Times Deny Ronald Reagan His Due.’ Policy Review. 82. March/April. 51-53.

Gee, David. 1993. 'Keith Jackson: Analyst of New Zealand Political Leaders.' 21 July. The Press: Christchurch. 13.

Globe Magazine. 1964. 'Rating the Prime Ministers.' 18 July. 8-12.

Gordon, Michael and Michelle Grattan. 2004. 'Curtin: Our Greatest PM.' 18 December. Age.

Grant, Ian F. 2003. Public Lives: New Zealand's Premiers and Prime Ministers 1856-2003. Wellington: New Zealand Cartoon Archive.

Gustafson, Barry. 1986. From the Cradle to the Grave: A Biography of Michael Joseph Savage. Auckland: Reed Methuen.

Hillmer, Norman and Stephen Azzi. 2011. 'Canada's Best Prime Ministers: Maclean's Second Survey of Our Greatest Leaders Shows a New Number One, and Some Big Surprises.' 10 June. Maclean's: Ottawa.

- 2013. 'Evaluating Prime-Ministerial Performance: The Canadian Experience.' In Strangio, Paul, Paul 't. Hart and James Walter, (eds). Understanding Prime Ministerial Performance: Comparative Perspectives. Oxford: Oxford University Press.

— 2016. 'Ranking Canada's Best and Worst Prime Ministers.' 7 October. Maclean's: Ottawa.

Hillmer, Norman and J. L. Granatstein. 1997. 'Historians Rank the Best and Worst Canadian Prime Ministers.' Maclean's. 110 (16). 34-39.

Hoxie, R. Gordon. 1977. Command Decision and the Presidency: A Study of National Security Policy and Organization. New York: Reader's Digest Press.

Jackson, Keith. 1975. 'Political Leadership and Succession in the New Zealand National Party.' Political Science. 27. (1 and 2). 1-24.

Janda, Kenneth, Jeffrey M. Berry and Jerry Goldman, eds. 1992. The Challenge of Democracy: Government in America. 3rd ed. Boston: Houghton Mifflin.

Johansson, Jon. 2002. Leadership in New Zealand: Theory and Practice. Doctoral Thesis. Wellington: Victoria University of Wellington.

- 2004. 'Muldoon and Character.' In Margaret Clark (ed). Muldoon Revisited. Palmerston North: Dunmore. p. 269-286. 
— 2005. Two Titans: Muldoon, Lange and Leadership. Wellington: Dunmore.

— 2009. The Politics of Possibility: Leadership in Changing Times. Wellington: Dunmore.

— 2013. 'Prime Ministers and Their Parties in New Zealand.' In Strangio, Paul, Paul 't. Hart and James Walter, (eds). Understanding Prime Ministerial Performance: Comparative Perspectives. Oxford: Oxford University Press.

Johansson, Jon and Stephen Levine. 2013. 'Evaluating Prime-Ministerial Performance: The New Zealand Experience.' In Strangio, Paul, Paul 't. Hart and James Walter, (eds). Understanding Prime Ministerial Performance: Comparative Perspectives. Oxford: Oxford University Press.

— 2012. 'Jon Johansson and Stephen Levine' Interview by Chris Laidlaw. Sunday Morning. Radio New Zealand. 1 July. Audio. 46’30”.

Kenney, Patrick J. and Tom W. Rice. 1988. 'The Contextual Determinants of Presidential Greatness.' Presidential Studies Quarterly. 18. (1): 161-69.

Kirkup, Jonathan and Stephen Thornton. 2017. "“Everyone Needs a Willie”: The Elusive Position of Deputy to the British Prime Minister.' British Politics. 12 (4): 492-520.

Kurtzleben, Danielle. 2016. 'Why Aren’t There More Women In Politics?' June 11. National Public Radio: Washington D.C

Levy, Don. 2002. FDR America's Greatest President. 19 August. Loudonville. Siena Research Institute.

Lonnstrom, Douglas A. and Thomas O. Kelly. 2003. 'The Contemporary Presidency: Rating the Presidents: A Tracking Study.' Presidential Studies Quarterly. 33. (3): 625-34.

— 2010. Rushmore Plus One; FDR Joins Mountainside Figures Washington, Jefferson, Teddy Roosevelt and Lincoln as Top Presidents. 1 July. Loudonville: Siena Research Institute.

Maranell, Gary M. 1970. 'The Evaluation of Presidents: An Extension of the Schlesinger Polls.' The Journal of American History. 57 (1): 104-13.

Mcallister, Ian. 1998. 'Civic Education and Political Knowledge in Australia.' Australian Journal of Political Science 33 (1): 7-23.

McLean, Gavin. 2012. 'Premiers and Prime Ministers.' June 20. Te Ara: The Encyclopedia of New Zealand.

Medford, Edna. 2009. 'C-SPAN's Historians Survey of Presidential Leadership.' C-Span. https://www.youtube.com/watch?v=P199ECf7q2s.

Miller, Raymond. 2008. 'Taming Leadership? Adapting to Institutional Change in New Zealand Politics.' In t'Hart, Paul and John Uhr, (eds). Public Leadership: Perspectives and Practices. Canberra: ANU Press. 
Miller, Raymond and Helena Catt. 1993. Season of Discontent: By-Elections and the Bolger Government. Palmerston North: Dunmore.

Miller, Raymond and Michael Mintrom (eds). 2006. Political Leadership in New Zealand. 1st ed. Auckland: Auckland University Press.

Morgan, Gary, and Michele Levine. 2017. 'National Party Support up Slightly in January as New Prime Minister Bill English Returns from 'Introductory Tour' to Europe: Roy Morgan Poll January 2017.' 20 January. Melbourne: Roy Morgan.

Morris, Grant. 2016. 'Who Was Our Best Prime Minister?'. Interview by Jesse Mulligan. Jesse Mulligan 1-4pm. Radio New Zealand. 8 September. Audio. 13'56".

Nichols, Curt. 2012. 'The Presidential Ranking Game: Critical Review and Some New Discoveries.' Presidential Studies Quarterly 42 (2). 275-299.

Norris, Pippa. 2004. Young People and Political Activism: From the Politics of Loyalties to the Politics of Choice? Cambridge: Harvard University. 1-32.

One News. 2017. 'One News Colmar Brunton Poll 11-15 February 2017.' Auckland: Colmar Brunton.

Policy Options. 2003. Special Issue on 'Ranking the Prime Ministers of the Last 50 Years.' June-July.

Power, Simon. 2004. 'The Ingredients of Successful Political Leadership.' Political Science. 56. (2). Routledge: 11-18.

Roediger, Henry L. and Andrew K. DeSoto. 2016. 'Recognizing the Presidents.' Psychological Science. 27. (5): 644-50.

Rottinghaus, Brandon and Justin S. Vaughn. 2015. 'Measuring Obama Against the Great Presidents.' 15 February. Brookings. Washington D.C.

— 2018. 'How Does Trump Stack Up Against the Best — and Worst — Presidents?' 19 February. The New York Times.

- 2018. 'Official Results of the 2018 Presidents and Executive Politics Presidential Greatness Survey.' Houston: University of Houston. 1-14.

Roughan, John. 2014. John Key: Portrait of a Prime Minister. 2nd ed. Auckland: Penguin Group (NZ).

Schlesinger, Arthur M. 1948. 'Historians Rate the US Presidents.' Life. 25. (18): 65-66.

— 1962. 'Our Presidents: Ratings by 75 Historians.' The New York Times, July. 12-13, 40$41,43$.

Schlesinger Jr., Arthur M. 1965. A Thousand Days: John F. Kennedy in the White House. Boston: Houghton Mifflin. 
— 1997. 'Rating the Presidents: Washington to Clinton.' Political Science Quarterly. 112 (2):179-90.

Scholefield, G. H. 1946. Notable New Zealand Statesmen: Twelve Prime Ministers. Auckland: Whitcombe \& Tombs.

Sheppard, Simon. 1998. 'Ranking New Zealand's Prime Ministers.' Political Science 50: $72-$ 89.

Shuttleworth, Kate. 2017. “Jacindamania”: Rocketing Rise of New Zealand Labour's Fresh Political Hope.' 2 September. The Guardian. London.

Simms, Marian. 2008. 'Women's Politics and Leadership in Australia and New Zealand.' Signs. 34 (1): 32-36.

— 2008. 'Are Women Leaders Different? Margaret Thatcher and Helen Clark.' In t'Hart, Paul and John Uhr, (eds). Public Leadership: Perspectives and Practices. Canberra: ANU Press. 275-284.

Simonton, Dean Keith. 2001. 'Predicting Presidential Performance in the United States: Equation Replication on Recent Survey Results.' The Journal of Social Psychology. 141. (3). Taylor \& Francis: 293-307.

Sinclair, Keith. 1959. A History of New Zealand. $5^{\text {th }}$ Ed. Auckland: Penguin.

Skidmore, Max J. 1993. Presidential Performance: A Comprehensive Review. Jefferson, North Carolina: McFarland \& Company.

Somin, Ilya. 2015. 'The Disturbing Growth of Partisan Bias.' 9 December. The Washington Post: Washington D.C.

Strangio, Paul. 2013. 'Evaluating Prime-Ministerial Performance: The Australian Experience.' In Strangio, Paul, Paul 't. Hart and James Walter, (eds). Understanding Prime Ministerial Performance: Comparative Perspectives. Oxford: Oxford University Press.

Strangio, Paul, Paul 't. Hart and James Walter, (eds). 2013. Understanding Prime Ministerial Performance: Comparative Perspectives. Oxford: Oxford University Press.

- 2017. The Pivot of Power: Australian Prime Ministers and Political Leadership 1949-2016. Melbourne: The Mieguyah Press.

Sunstein, Cass. 2014. “"Partyism” Now Trumps Racism.' 23 September. Bloomberg: New York.

Taranto, James. 2005. 'Presidential Leadership: The Rankings.' 12 September. Wall Street Journal: New York.

— 2005. 'How's He Doing? George Bush Is “Average” But Far From Ordinary.' 12 September. Wall Street Journal: New York. 
t'Hart, Paul and John Uhr, (eds). 2008. Public Leadership: Perspectives and Practices. Canberra: ANU Press.

Theakston, Kevin. 2013. 'Evaluating Prime-Ministerial Performance: The British Experience.' In Strangio, Paul, Paul 't. Hart and James Walter, (eds). Understanding Prime Ministerial Performance: Comparative Perspectives. Oxford: Oxford University Press.

Theakston, Kevin and Mark Gill. 2006. 'Rating 20th-Century British Prime Ministers.' The British Journal of Politics and International Relations. 8. (2): 193-213.

Walker, T. and J Koutsoukis. 2001. 'The Good, the Bad and the Couldabeens.' 3 January. Australian Financial Review.

Walter, James. 2013. 'Personal Style, Institutional Setting and Historical Opportunity: PrimeMinisterial Performance in Context.' In Strangio, Paul, Paul 't. Hart and James Walter, (eds). Understanding Prime Ministerial Performance: Comparative Perspectives. Oxford: Oxford University Press.

Wolfe, Richard. 2005. Battlers, Bluffers and Bully-Boys: How New Zealand's Prime Ministers Have Shaped Our Nation. Auckland: Random House.

Young, Oran R. 1991. 'Political Leadership and Regime Formation: On the Development of Institutions in International Society.' International Organization 45 (3): 281-308. 